\author{
EFEITOS DE PERIODOS CRESCENTES DE HIDRATAÇÃo \\ SEGUIDOS DE SECAGEM NO DESEMPENHO FISIOLOGICO E NA \\ SANIDADE DE SEMENTES DE TRIGO
}

CARLOS AUGUSTO PEREIRA MOTTA
Engenheiro Agrônomo

Orientador: Prof. Dr. WALTER RODRIGUES DA SILVA

Tese apresentada à Escola Superior de Agricultura "Luiz de Queiroz", da Universidade de São Paulo, para a obtenção do título de Doutor em Agronomia. Area de Concentração: Fitotecnia.

P I RAC I CABA

Estado de São Paulo - Brasil

Janeiro - 1994 
Ficha catalografica preparada pela Seçào de Livros da Divisăo de Biblioteca e Documentạ̧á - PCLQ/USF

Motta. Carlos Augusto Fereira

M921e Efeitos de perídos crescentes de hidrataça segui dos de secagem no desempento fisiologico e na sanidade de sementes de trigo. Piracicaba, 1994.

$146 p$.

Tese - ESALE

Eibliografiā.

1. Semente - Germinaçaro 2. Semente - Qualidade Tratamento 3 . Trigo - Semente I. Escola Superior de Agricultura Luiz de Bueiroz, Piracicaba 
EFEITOS DE PERIOdOS CRESCENTES DE HIDRATAÇÃO SEGUIDOS DE SECAGEM NO DESEMPENHO FISIOLOGICO E NA SANIDADE DE SEMENTES DE TRIGO

CARLOS AUGUSTO PEREIRA MOTTA

Aprovada em: 18.03.1994

Comissão julgadora:

Prof. Dr. Malter Rodrigues da Silva

ESALQ/USP

Prof. Dr. Silvio Moure Cícero

ESALQ/USP

Prof. Dr. Francisco Ferraz de Toledo

ESALQ/USP

Prof. Dr. Nelson Moreira de Carvalho

FCAV/UNESP

Prof. Dr. Roberval Daiton Vieira

FCAV/UNESP

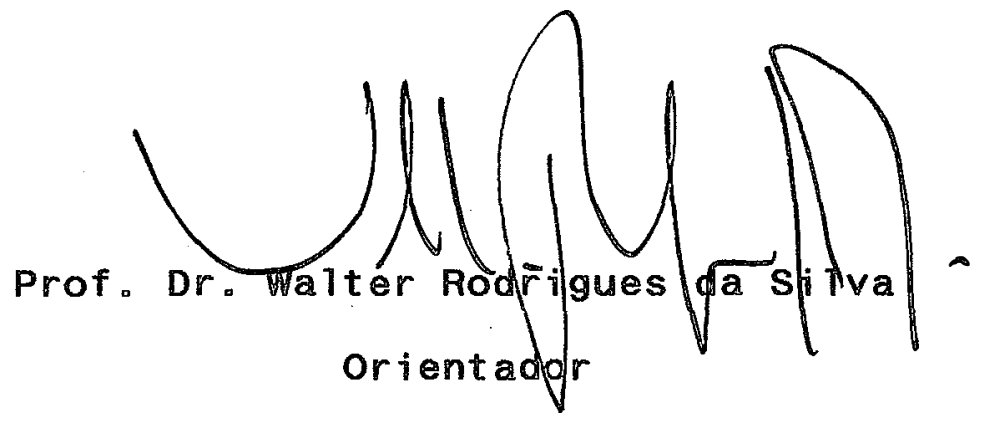


Aos meus pais

Milton (in memorian) e Dirce,

exemplos de luta e dignidade.

As minhas filhas

Maíra, Maitê, Lígia e Vivian, que me fizeram compreender $o$ verdadeiro significado da ternura. 


\section{AGRADECIMENTOS}

Ao professor Walter Rodrigues da Silva, pela orientação e assistência na redação deste trabalho.

Ao Corpo Docente da ESALQ/USP, especialmente aos professores Jairo Teixeira Mendes Abrahão e Francisco Ferraz de Toledo, pelo apoio e amizade.

Aos funcionários da da ESALQ/USP, em especial às Engenheiras Agrônomas Helena C. Pescarin, Ana Dionísia $L$. C. Novembre e à Técnica Administrativa Ilze Helena C. G. das Neves, pela colaboração.

Aos colegas de curso, especialmente, aos amigos Francisco do Amaral Villela e Luiz Doni Filho, pelo estímulo e amizade.

Aos funcinários do IAPAR, em especial às técnicas dos Laboratórios de Análise de sementes e de Patologia de sementes Maria Catarina Perez, Ana Luísa M. Nicontchuk e à técnica administrativa Vilma Neide Alves, pela colaboração dedicada.

Aos pesquisadores do IAPAR, Rogério Teixeira de Faria e José Carlos de oliveira pela colaboração.

A Fundação IAPAR e ao CNPq, pela oportunidade e suporte financeiro.

A todos que de alguma forma contribuiram para a realização do curso. 
SUMÁRIO

Página

LISTA DE FIGURAS $\ldots \ldots \ldots \ldots \ldots \ldots \ldots \ldots \ldots \ldots \ldots \ldots \ldots \ldots$

LISTA DE TABELAS $\ldots \ldots \ldots \ldots \ldots \ldots \ldots \ldots \ldots \ldots \ldots \ldots \ldots \ldots \ldots$

RESUMO $\ldots \ldots \ldots \ldots \ldots \ldots \ldots \ldots \ldots \ldots \ldots \ldots \ldots \ldots \ldots \ldots \ldots \ldots \ldots \ldots \ldots$

SUMARY $\ldots \ldots \ldots \ldots \ldots \ldots \ldots \ldots \ldots \ldots \ldots \ldots \ldots \ldots \ldots \ldots \ldots \ldots \ldots$

1. INTRODUÇAO $\ldots \ldots \ldots \ldots \ldots \ldots \ldots \ldots \ldots \ldots \ldots \ldots \ldots \ldots$

2. REVISÃo de LiteRATURA ................. 4

2.1. A função do conteúdo de água no controle dos processos de desenvolvimento, maturação e e germinação de sementes ............... 5

2.2. A hidratação e o processo de germinacão de

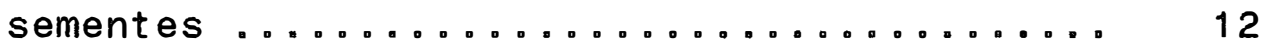

2.3. Efeito da secagem durante o processo de

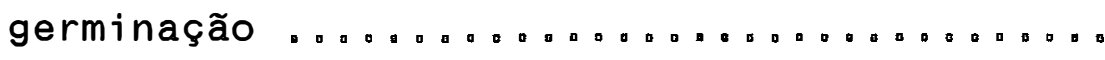

2.4. Processos fisiológicos relacionados ao teor de água das sementes durante o armazenamento 2.4.1. Mudanças associadas à deterioração das sementes durante 0 armazenamento...

2.4.2. Ativação fisiológica e mecanismos de

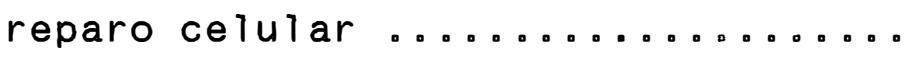

2.5. Tratamentos de Hidratação/Desidratação ...

2.6. Mecanismos de controle de patógenos em sementes $\ldots \ldots \ldots \ldots \ldots \ldots \ldots \ldots \ldots \ldots \ldots$ 
3. MATERIAL E MÉTODOS ................. 49

3.1. Escolha e caracterização das sementes ..... 49

3.2. Obtenção e caracterização dos tratamentos .. 51

3.3. Avaliação dos efeitos dos tratamentos ..... 56

3.3.1. Estudo 1................. 56

3.3.2. Estudo $2 \ldots \ldots \ldots \ldots \ldots \ldots \ldots . \ldots \ldots$

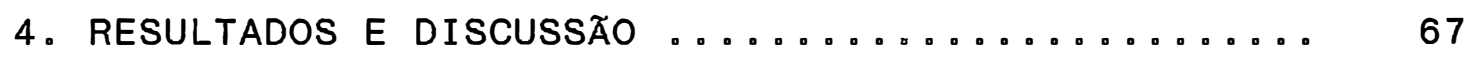

4.1. Caracterização dos tratamentos ......... 67

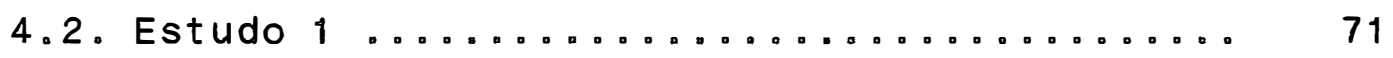

4.2.1. Avaliação do desempenho fisiológico . 71

4.2.2. Avaliação da sanidade das sementes.. 85

4.2.3. Estudo 1. Considerações gerais ...... 90

4.3. Estudo $2 \ldots \ldots \ldots \ldots \ldots \ldots \ldots \ldots \ldots \ldots . \ldots \ldots$

4.3.1. Caracterização dos grupos de estádios desenvolvimento ............. 93

4.3.2. Desempenho fisiológico .......... 96

4.3.3. Estudo 2. Considerações gerais ..... 113

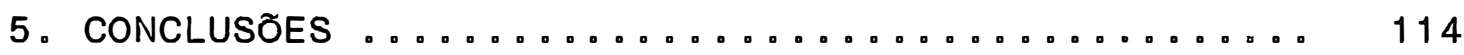

6. REFERENCIAS BIBLIOGRÁFICAS $\ldots \ldots \ldots \ldots \ldots \ldots \ldots$ 
vi.

\section{LISTA DE FIGURAS}

Figura

Página

1. Esquemas das sementes representantes dos estádios de desenvolvimento considerados na caracterização dos tratamentos ...............

2. Marcha de absorção de água, em função do período de hidratação, de sementes de trigo dos cultivares OCEPAR 7 - Batuíra e CEP 14 - Tapes.

3. Estudo 1. Germinação: curvas de regressão polinomial para os efeitos dos tratamentos de hidratação e secagem em sementes de trigo dos cultivares OCEPAR 7 - Batuíra e CEP 14 - Tapes

4. Estudo 1. Emergência em areia: curvas de regressão polinomial para os efeitos dos tratamentos de hidratação e secagem em sementes de trigo dos cultivres OCEPAR 7 - Batuíra e

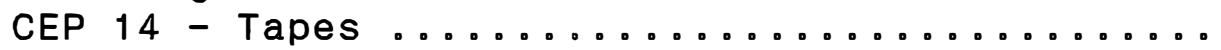

5. Estudo 1. Primeira contagem de germinação: curvas de regressão polinomial para os efeitos dos tratamentos de hidratação e secagem em sementes trigo dos cultivares OCEPAR 7 - Batuíra

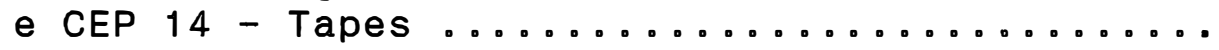

6. Estudo 1. Indice de velocidade de emergência em areia: curvas de regressão polinomial para os efeitos dos tratamentos de hidratação e secagem em sementes de trigo dos cultivares OCEPAR 7 -

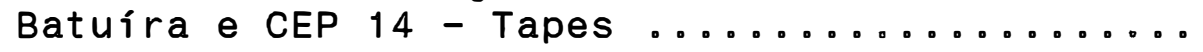

7. Estudo 1. Comprimento de plântulas: curvas regressão polinomial para os efeitos dos tratamentos de hidratação e secagem em sementes de trigo dos cultivares OCEPAR 7 - Batuira e

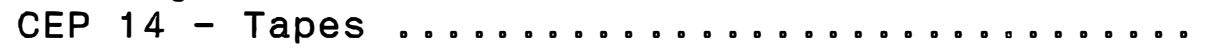

8. Estudo 1. Peso da matéria seca de plântulas: curvas de regressão polinomial para os efeitos dos tratamentos de hidratação e secagem, em sementes de trigo dos cultivares OCEPAR 7 -

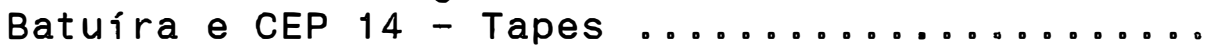


9. Estudo 1: Condutividade elétrica do meio de embebição: curvas de regressão polinomial para os efeitos dos tratamentos de hidratação e secagem em sementes de trigo dos cultivares OCEPAR 7 - Batuíra e CEP 14 - Tapes...........

10. Estudo 1. Fungo de campo Helminthosporium spp: variação nos valores médios de incidência (\%), em função do tratamento de hidratação e secagem, nas sementes de trigo dos cultivares OCEPAR 7 - Batuíra e CEP 14 - Tapes ..........

11. Estudo 1. Fungos de armazenamento Penicilium spp.e Aspergillus spp.: variação na soma dos valores médios de incidência (\%), em função do tratamento de hidratação e secagem, em sementes dos cultivares de trigo OCEPAR 7 -

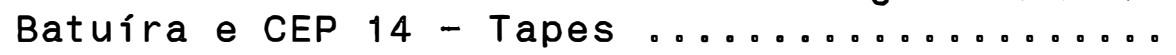

12. Estudo 1. Sementes isentas de patógenos: variação nos valores médios de ocorrência (\%) em função do tratamento de hidratação e secagem, para os cultivares de trigo OCEPAR 7 - Batuíra e CEP 14

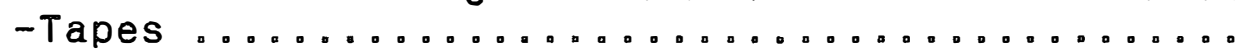

13. Estudo 2. Conteúdo (\%) de água de sementes distribuidas em grupos estabelecidos, de acordo com o estádio de desenvolvimento germinativo alcançado, em períodos de hidratação variáveis..

14. Estudo 2. Germinação: curvas de regressão polinomial para os efeitos dos tratamentos de hidratação e secagem, em sementes de trigo (cv. Batuíra) agrupadas segundo estádios de

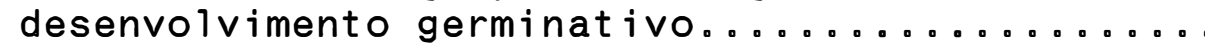

15. Estudo 2. Emergência em areia: curvas de regressão polinomial para os efeitos dos tratamentos de hidratação e secagem, em sementes de trigo (cv. Batuíra) agrupadas segundo estádios de desenvolvimento germinativo.........

16. Estudo 2. Primeira contagem de germinação: curvas de regressão polinomial para os efeitos dos tratamentos de hidratação e secagem, em sementes de trigo (cV. Batuira) agrupadas segundo estádios de desenvolvimento germinativo. 
17. Estudo 2. Indice de velocidade de emergência em areia: curvas de regressão polinomial para os efeitos dos tratamentos de hidratação e secagem, em sementes de trigo ( $c v$. Batuíra) agrupadas segundo estádios de desenvolvimento germinativo

18. Estudo 2. Comprimento de plântulas: curvas de regressão polinomial para os efeitos dos tratamentos de hidratação e secagem, em sementes de trigo (cv. Batuíra) agrupadas segundo estádios de desenvolvimento germinativo........

19. Estudo 2. Condutividade elétrica do meio de embebição: curvas de regressão polinomial para os efeitos dos tratamentos de hidratação e secagem, em sementes de trigo agrupadas segundo estádios de desenvolvimento germinativo........ 
1. Caracteristicas iniciais dos lotes de sementes de trigo dos cultivares OCEPAR 7 - Batuira e

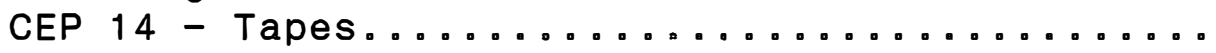

2. Denominação dos tratamentos e respectivos periodos de hidratação precedentes à secagem....

3. Estudo 2. Caracterização dos agrupamentos de sementes estabelecidos, em relação às etapas do processo de germinação envolvidas e aos estádios de desenvolvimento reunidos...........

4. Estudo 2. Relação dos períodos de hidratação em que foram obt $i d a s$ as sementes representantes de cada grupo de desenvolvimento germinativo.......

5. Teor de água e distribuição da ocorrência (\%) de individuos, apresentando diferentes estádios de desenvolvimento germinativo, nas amostras de sementes de trigo, cultivar OCEPAR 7 - Batuira, submetidas a períodos variáveis de hidratação...

6. Teor de água e distribuição da ocorrência (\%) de individuos, apresentando diferentes estádios de desenvolvimento germinativo, nas amostras de sementes de trigo, cultivar CEP 14 - Tapes, submetidas a períodos variáveis de hidratação....

7. Estudo 1. Comparação entre as médias (\%) dos testes de germinação e de emergência em areia, para os efeitos de tratamentos hidratação variáveis (de 0 a 48 horas), seguidos de secagem, em sementes de trigo dos cultivares OCEPAR 7 - Batuíra e CEP 14 - Tapes...........

8. Estudo 1. Comparação entre as médias dos testes de primeira contagem de germinação (\%) e de velocidade de emergência em areia (índice), para os efeitos de tratamentos de hidratação variáveis (de 0 a 48 horas), seguidos de secagem, em sementes de trigo dos cultivares OCEPAR 7 - Batuira e CEP 14 - Tapes........... 
9. Estudo 1. Comparação entre as médias obtidos nas avaliações do comprimento $(\mathrm{cm} / \mathrm{pl}$.) e do peso de matéria seca (mg/pl.), das plântulas, para os efeitos de tratamentos de hidratação (variáveis de 0 a 48 horas), seguidos de secagem, em sementes de trigo dos cultivares OCEPAR 7 -

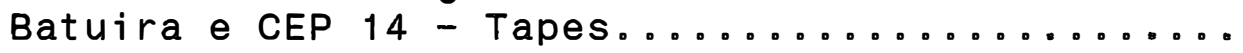

10. Estudo 1. Comparação entre as médias da determinação da condutividade elétrica do meio de embebição, para os efeitos de tratamentos de hidratação (variáveis de 0 a 48 horas) seguidos de secagem, em sementes de trigo dos cultivares OCEPAR 7 - Batuira e CEP 14 - Tapes.............

11. Estudo 2. Distribuição (\%) da ocorrência na população de cada período de hidratação e teor de água de sementes agrupadas segundo o estádio de desenvolvimento atingido no processo de

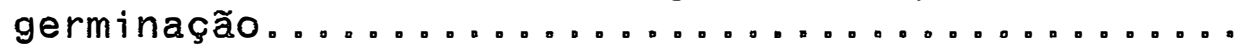

12. Estudo 2. Germinação: valores médios (\%) obtidos pela população total de sementes e pelos grupos formados, em função do estádio de desenvolvimento germinativo atingido, após os tratamentos de

hidratação (variáveis de 0 a 48 horas) que

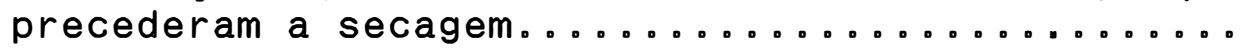

13. Estudo 2. Emergência em areia:valores médios (\%) obtidos pela população total de sementes e pelos grupos formados, em função do estádio de desenvolvimento germinativo atingido, após os tratamentos de hidratação (variáveis de 0 a 48h)

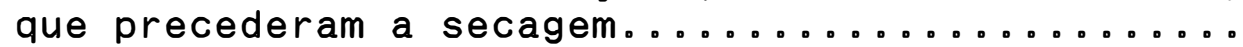

14. Estudo 2.Primeira contagem de germinação: valores médios (\%) obtidos pela população total de sementes e pelos grupos formados, em função do estádio de desenvolvimento germinativo atingido, após os tratamentos de hidratação (variáveis de 0 a 48 horas) que precederam a secagem..........

102

15. Estudo 2. Indice de velocidade de emergência: valores médios obtidos pela população total de sementes e pelos grupos formados, em função do estádio de desenvolvimento germinativo atingido, após os tratamentos de hidratação (variáveis de 0 a 48 horas) que precederam a secagem.......... 
$x i$

16. Estudo 2. Comprimento de plântulas: valores médios $(\mathrm{cm} / \mathrm{pl}$.) obtidos pela população total de sementes e pelos grupos formados, em função do estádio de desenvolvimento germinativo atingido, após os tratamentos de hidratação (variáveis de o a 48 horas) que precederam a secagem..........

17. Estudo 2. Condutividade elétrica: dados médios ( Umhos/cm/g) obtidos pela população total de sementes e pelos grupos formados, em função do estádio de desenvolvimento germinativo atingido, após os tratamentos de hidratação (variáveis de o a 48 horas), que precederam a secagem.......... 


\title{
EFEITOS DE PERIODOS CRESCENTES DE HIDRATAÇÃO \\ SEGUIDOS DE SECAGEM NO DESEMPENHO FISIOLOGICO E NA SANIDADE DE SEMENTES DE TRIGO
}

\author{
Autor: CARLOS AUGUSTO PEREIRA MOTTA \\ orientador: PROF. DR. WALTER RODRIGUES DA SILVA
}

\section{RESUMO}

o presente trabalho teve por objetivo avaliar os efeitos da secagem, após periodos crescentes de hidratação, no desempenho fisiológico e na sanidade de sementes de trigo (Triticum aestivum L.).

Para tanto, sementes de trigo dos cultivares OCEPAR 7 - Batuíra e CEP 14 - Tapes foram submetidas a periodos variáveis de 3 a 48 horas de hidratação, sob temperatura constante de $20^{\circ} \mathrm{C}$, em papel toalha umedecido com água destilada. A intervalos de 3 horas, amostras de sementes, de cada periodo de hidratação, foram retiradas dos substratos, caracterizadas quanto ao teor de água absorvido e ao estádio de desenvolvimento atingido dentro do processo de germinacão e, em seguida, submetidas à secagem em estufa regulada a $30^{\circ} \mathrm{C}$, até atingirem a umidade original.

A avaliação dos tratamentos de hidratação constou de dois estudos. No primeiro, realizado em ambos os cultivares, amostras completas dos tratamentos de 
hidratação/desidratação foram avaliadas quanto à qualidade fisiológica, através de testes laboratoriais de viabilidade e vigor, e quanto ao estado sanitário. Os resultados obtidos nos tratamentos foram comparados entre si e com testemunhas não hidratadas.

No segundo estudo, conduzido com 0 cultivar OCEPAR 7- Batuíra, avaliou-se o desempenho fisiológico de sementes que, fixados os periodos de hidratação, foram agrupadas segundo estádios visíveis de desenvolvimento. Foram estabelecidos quatro grupos de desenvolvimento, considerando as sementes embebidas, a emergência da coleorriza, a emissão e o crescimento da raíz primária. Os resultados apresentados pelos grupos, presentes num mesmo periodo de hidratação, foram comparados entre si e com os da amostra total de origem. Comparou-se, ainda, o desempenho de sementes de um mesmo grupo obtidas em diferentes períodos de hidratação.

A análise dos dados e a interpretação dos resultados permitiram as seguintes conclusões: - A sensibilidade à desidratação se manifesta quando a concentração de água nas amostras de sementes de trigo atinge niveis superiores a $42 \%$, o que ocorreu a partir de 30 horas do início da hidratação.

- A emissão da raíz primária, por si só, não representa um referencial adequado para a definição do momento, a partir do qual, as sementes tornam-se sensiveis 
à desidratação. Embora a secagem conduza à morte da raíz primária, com a reidratação, o desenvolvimento radicular é retomado, a partir de iniciações secundárias.

- A tolerância à desidratação, durante o processo de germinação, varia com o cultivar, com o estado fisiológico das sementes, com o nivel de hidratação das sementes individuais, e com o parâmetro fisiológico ava 1 iado.

- As sementes que, em uma amostra submetida a hidratação, atingem estádios mais avançados de desenvolvimento, apresentam melhor desempenho e maior tolerância à desidratação.

- Os melhores resultados, nos aspectos

fisiológico e sanitário, foram obtidos nos tratamentos em que, antes da secagem, as amostras de sementes atingiram teores de água entre 34 e $42 \%$, correspondendo aos periodos de hidratação, situados entre 15 e 30 horas. 


\title{
EFFECTS OF INCREASING PERIODS OF HYDRATION \\ FOLLOWED BY DRYING ON THE PHYSIOLOGICAL PERFORMANCE AND \\ HEALTH ASPECTS OF WHEAT SEEDS
}

\author{
Author: CARLOS AUGUSTO PEREIRA MOTTA \\ Adviser: Prof. Dr. WALTER RODRIGUES DA SILVA
}

\section{SUMMARY}

The effects of increasing periods of hydration, followed by drying, on the physiological performance and health aspects of wheat (Tryticum aestivum L.) seeds were evaluated. Wheat seeds of the cultivars OCEPAR 7 - Batuira e CEP 14 - Tapes, placed in distilled water moisten towel paper, were submitted to periods of hydration varying from 3 to 48 horas, under constant temperature of $20^{\circ} \mathrm{C}$. At 3 hours intervals, seed samples of each hydration treatment were taken from substract to characterize water absorption and germination development stage of the seeds. Then, the material was oven dried at $30^{\circ} \mathrm{C}$ until the seeds reached the original moisture.

Treatments were evaluated according to test

sets. In the first set, complete seed samples of the two ciltivars, submitted to the different treatments, were evaluated and compared for physiological aspects, including laboratory tests of viability and vigor, and health state of the seeds. 
In the second set, seeds of the cultivar OCEPAR 7 - Batuira were used to evaluate the physiological performance of the seeds. For fixed hydration periods, 4 groups of seed development were defined as: imbibition, emergence of the coleorhiza, appearance and development of the primary root. The results obtained for each group were evaluated and compared with the seeds of different groups, and with the original population in each treatment. Furthermore, the physiological aspects of a same group was compared for different hydration periods.

The analysis of the results allowed the following conclusions:

- Sensitivity of drying is evident when seeds samples reached moisture contents above $42 \%$, which occurs after 30 hours from the beginning of hydration.

- The emission of the primary root alone is not a suitable indicator for determination of the moment, during the germination process, in which seeds become sensitive to drying. Drying leads to primary root death. However, root development takes place after rehydration by secondary root initiations.

- Tolerance to drying during the germination process varies with cultivar, physiological conditions of seeds, level of hydration, and parameter evaluated.

- The best performance and tolerance to dehydration are found in seeds, from a given population 
submitted to hydration, that reach a more advanced development stage.

- The best physiological and sanitary performance are obtained for treatments in which seeds reach moisture contents between $34 \%$ and $42 \%$, corresponding to hydration periods from 15 to 30 hours, before drying. 


\section{INTRODUÇÃO}

As sementes, agronomicamente viáveis e não dormentes, retomam o desenvolvimento normal do embrião através da germinação, quando encontram-se satisfeitas as condições exógenas requeridas pela espécie. Uma vez satisfeitos os requisitos de temperatura, de luz e de composição do ar, o processo de germinação se inicia a partir do fornecimento de água à semente que, promovendo a hidratação dos tecidos, devolve as condições favoráveis à atividade metabólica necessária para a retomada do desenvolvimento embrionário.

o conhecimento do nível de hidratação dos tecidos necessário para desencadear as atividades metabólicas envolvidas no processo de germinação, motivou a realização de vários estudos sobre a absorção de água pelas sementes, assim como sobre as necessidades hidricas nessa fase de desenvolvimento em numerosas espécies.

Os estudos sobre a absorção de água pelas sementes, durante o processo de germinação, mostraram que a embebição ocorre em etapas específicas quanto aos fenômenos fisiológicos que a acompanha. A partir de um nível crítico de hidratação as sementes germinarão; 
contudo, substancial atividade metabólica ocorrerá na semente parcialmente hidratada.

No campo, são de ocorrência comum as nas quais o suprimento de água em quantidades favoráveis à germinação é interrompido após o processo ter sido iniciado. É o que acontece, por exemplo, em sementes de alguns cultivares de trigo que, não apresentando dormência de pós maturidade, atravessam períodos chuvosos na época de pré-colneita. outro exemplo é o que ocorre nas semeaduras em solos com baixa disponibilidade hidrica; algumas sementes podem absorver água em quantidade suficiente apenas para iniciar a germinação, permanecendo no solo impossibilitadas de continuar o processo.

Nas condições de campo, portanto, as sementes estão sujeitas a ciclos sucessivos de hidratação e desidratação e, dependendo das condições de disponibilidade' hidrica, a germinação pode ser interrompida em diferentes estádios do processo. Considera-se, no entanto, que as sementes tornam-se mais sensiveis à desidratação na medida em que avançam no processo de germinação e que, a secagem a partir da fase visivel do processo, normalmente expressada através da emissão da raiz primária, pode provocar danos irreparáveis ao embrião, a ponto da germinação não se retomar quando a semente for reembebida.

Por outro lado, estudos têm demonstrado 
que, durante a embebição, existe a possibilidade de ocorrer um acréscimo qualitativo no desempenho fisiológico das sementes, através da ativação de mecanismos fisiológicos de reparo de tecidos, membranas e organelas celulares, que pode ser fixado com a secagem. A embebição prévia das sementes seguida de secagem pode, ainda, reduzir a ação dos patógenos presentes, quer pelo efeito da secagem sobre os microrganismos, ou pela ativação de mecanismos de defesa presentes na própria semente.

Desta forma, considerando as situações análogas de campo e, além disso, diante da possibilidade de utilização da hidratação e desidratação controladas, como um método de tratamento prévio das sementes visando a melhoria de suas qualidades fisiológica e sanitária, o presente trabalho objetivou:

- Determinar o periodo limite de embebição e o nível de hidratação, a partir dos quais as sementes de trigo tornam-se sensiveis à desidratação.

- Verificar a ação da secagem, após diversos periodos de embebição, na qualidade fisiológica e na sanidade das sementes. 


\section{REVISÃO DE LITERATURA}

2.1. A função do conteúdo de água no controle dos processos de desenvolvimento, maturação e germinação de sementes

Durante o desenvolvimento da semente, um período de repouso normalmente intervém entre o desenvolvimento do embrião e sua germinação. Os fatores de controle que promovem o repouso são, ainda, pouco conhecidos, mas envolvem constrangimentos impostos pelos tecidos maternos e, provavelmente, inibidores entre os quais o ácido abscísico (BEWLEY \& BLACK, 1985; KERMODE, et a 1., 1986).

A desidratação durante o desenvolvimento pode, no entanto, permitir que a semente adquira a germinabilidade (MITCHELL et a1., 1978). Sementes de trigo imaturas, em fases precoces do desenvolvimento, podem germinar após a secagem e, em estádios avançados, germinam em taxas mais elevadas do que suas correspondentes não secas (KING, 1976; KERMODE, et a 1., 1986).

Embriões imaturos, extraídos de algumas espécies, podem germinar em meio de cultura, imediatamente 
ou após um breve periodo de repouso, sem a necessidade da dessecação. Dessa forma, a supressão das ligações com a planta mãe (e também dos tecidos maternos que envolvem o embrião) pode ser suficiente para que a germinação seja induzida (KERMODE et al., 1986).

A dessecação, no entanto, é o evento terminal no desenvolvimento da maioria das sementes; pode, por si só, conduzir à perda dos controles, oriundos da planta mãe ou dos tecidos adjacentes ao embrião, ao afetar - fluxo de substâncias que inibem a germinação (por exemplo, o ácido abscísico) ou alterar a sensibilidade do embrião às substâncias supressoras ou promotoras desse processo (KERMODE et a1., 1986; MEURS et a1., 1991).

As sementes, contudo, parecem não ser tolerantes à secagem em todos os estádios de seu desenvolvimento; podem sofrer transição de um estado intolerante à desidratação para um tolerante num momento particular (THOMAS, 1972; KERMODE et al., 1986). Tem sido sugerido que as membranas celulares desempenham um papel importante nessa transição e uma mudança na sua estrutura e composição (por exemplo, o grau de insaturação de ácidos graxos), pode estar relacionada com a tolerância à desidratação (ROGERSON \& MATTHEWS, 1977; DASGUPTA, et al., 1982; CHEN \& BURRIS, 1990; 1991). A secagem, durante o estádio tolerante, suprime eventos metabólicos relacionados ao desenvolvimento e induz outros relativos à 
germinação (KERMODE et a1., 1986; BLACKMAN et a 1.1991).

THOMAS (1972) e KERMODE et a1. (1986), analisaram o processo de desidratação durante a maturação das sementes. Algumas das mudanças na organização da célula, que ocorrem quando as sementes amadurecem, são expressões diretas das mudanças no estado das membranas celulares e podem estar relacionadas às mudanças bioquimicas das sementes em desidratação. A semente, em maturação, está sujeita a estresse de água suficiente para estimular as mudanças na atividade respiratória e na sintese de enzimas; estas mudanças, na atividade metabólica, são adaptações que viabilizam a resistência celular à desidratação.

Uma análise comparativa, entre a formação da semente e a germinação, revela que os principais eventos associados com a fase anterior são notavelmente diferentes daqueles envolvidos com a posterior. As proteinas e, presumivelmente, os RNAm, sintetizados durante a maturação, são, diferentes dos produzidos durante a germinação (THOMAS, 1972; KERMODE, et a 1.,1986). Além disso, durante a formação, o metabolismo de muitas células é dirigido no sentido da sintese maciça de materiais de reserva (anabolismo) tais como proteinas, lipidios e carboidratos, enquanto que o reverso do processo (catabolismo das reservas) é efetuado na germinação. Como, na maioria das sementes, o periodo de 
desidratação é, naturalmente, interpolado pela maturidade e a germinação, é possível supor, que a perda de água execute algum papel na alternância?das atividades celulares, de um processo de desenvolvimento para outro, orientado exclusivamente para a germinação e crescimento (THOMAS, 1972; KERMODE et alii, 1986).

A partir da maturidade fisiológica, a semente perde água até atingir teores de equilíbrio higroscópico, variáveis segundo as condições ambientais prevalecentes. Uma das consequências desse processo, é o colapso funcional de células da zona de ligação com a planta mãe. Apesar de ser um fenômeno parcialmente ativo, a desidratação é afetada, particularmente, pela umidade atmosférica (LABOURIAU, 1983; KERMODE et al., 1986; BRYANT, 1989 ).

A desidratação promove, ainda, uma condição fisiológica, muito peculiar às sementes, que leva à interrupção do crescimento do embrião. Além disso, conduz a outras manifestações de um quadro fisiológico onde as trocas de matéria e energia, entre a semente e o ambiente externo, ocorrem em níveis e velocidades extremamente baixos (LABORIAU, 1983). Esta condição estabelece um estado de latência, referido por LABORIAU (1983) como criptobiose, no qual a semente torna-se menos sensivel às condições ambientais do que outras estruturas vegetais. A semente, nesse estado, está pronta para ser dispersada e 
- embrião, na maioria dos casos, está preparado para se tornar uma planta independente. Sob vários aspectos, a semente está apta para germinar.

No entanto, neste estádio, muitas espécies apresentam sementes que não estão apenas quiescentes, mas desenvolvem mecanismos de dormência e, portanto, não germinarão, mesmo quando submetidas a condições apropriadas. Esse mecanismo impede que a semente germine, mesmo no caso de ser reidratada quando ainda em contato com a planta-mãe (LABORIAU, 1983; BRYANT, 1989). O grau de dormência é dependente de fatores ambientais que operam durante o desenvolvimento da semente, particularmente a temperatura. Sementes de trigo, cevada e aveia silvestre são mais dormentes na maturidade quando o desenvolvimento ocorreu em baixas temperaturas $\left(10-20^{\circ} \mathrm{C}\right.$, por exemplo), do que em mais elevadas $\left(20-28^{\circ} \mathrm{C}\right.$ ) (BEWLEY \& BLACK, 1985). E essencial, na maioria dos casos, que as mudanças associadas à germinação não ocorram nas sementes antes da colheita, o que poderia provocar prejuizos na qualidade. Contudo, grande parte das plantas cultivadas, e entre essas muitos cultivares de trigo, não apresentam sementes com dormência de pós-maturidade havendo, então, a possibilidade de ocorrer a germinação antes da colheita quando as condições prevalecentes no periodo forem favoráveis ao fenômeno (BAUER \& BLACK, 1983; BEWLEY \& BLACK, 1985; ELIAS \& COPELAND, 1987; CLARKE \& DePAUW, 
1989); é o chamado "brotamento" em pré-colneita que, em alguns anos, é responsável por grandes perdas para a agricultura (BEWLEY \& BLACK, 1985).

o problema de brotamento é mais frequente em cultivares de trigo com sementes de tonalidade clara e de textura macia (BAUER \& BLACK, 1983; MCCRAIG \& DePAUW, 1992), do que nos de sementes vermelhas e duras. A resistência ao brotamento é governada pela dormência das cariópses e por características físicas, das espigas, que dificultam a absorção de água pelas sementes (DERERA et a1., 1977). A dormência é controlada por gens múltiplos que, paralelamente, governam a cor da cariópse (FREED et a 1., 1976; MCCRAIG \& DePAUW, 1992).

GORDON (1979) relatou que o fato das cariópses vermelhas de trigo exibirem dormência e pouco de dano por brotamento na espiga, pode ser devido à presença de flavanoides que, apesar de não atuarem como inibidores diretos da germinação, contribuem para a hipoxia dos embriões. o brotamento, contudo, ocorre esporadicamente em trigo de primavera vermelho e duro (BRIGGLE, 1980; CAMPBELL \& CZARNECK, 1981; BAUER \& BLACK, 1983)。

A germinação de sementes na espiga de cultivares de trigo suscetíveis ao brotamento, contudo, nem sempre ocorre quando a cultura madura é umedecida pela chuva. Embora a hidratação da semente seja necesssária para que ocorram a at ivação metabólica e a síntese de enzimas 
necessárias para iniciar a germinação, a concentração mínima de água requerida pelo trigo, para esse processo, está no intervalo de 35 a $40 \%$ de $\mathrm{H}_{2} \mathrm{O}$ (GORDON et al., 1977; DERERA, 1980; BAUER \& BLACK, 1983).

HUANG et a1.(1983) relataram que as cariópses de cor branca embebem água mais rapidamente do que as vermelhas; cariópses brancas, de cultivares suscetíveis ao brotamento, embeberam água mais rapidamente do que outras da mesma cor pertencentes a cultivares resistentes. KING (1984), contudo, não encontrou diferenças entre a absorção de água de cariópses vermelhas e brancas provenientes de linhas isogênicas.

Outros fatores influenciam a taxa de absorção de água pelas cariópses de trigo. Lotes de sementes, produzidos em diferentes condições ambientais, podem diferir na taxa de absorção de água (CLARKE, 1980); mesmo dentro de um único campo, as sementes individuais podem atingir diferentes niveis de hidratação (HEGARTY, 1978). KING (1984) relatou que a dureza do grão e o conteúdo de proteína não afetam a absorção de água, enquanto BUTCHER \& STENVERT (1973) associaram o alto conteúdo de proteína com as menores taxas de absorção.

A interrupção do fornecimento de água, no período de pré-colheita, pode ocorrer após as sementes terem atingido diferentes estádios de germinação que, nem sempre, são facilmente perceptíveis. Há casos em que o 
crescimento das raízes e do coleóptilo é evidente; há outros, no entanto, em que, apesar do crescimento das estruturas embrionárias não ser aparente, ocorreram os processos iniciais de ativação metabólica da germinação ou, embora o coleóptilo e as raízes apresentem algum desenvolvimento, encontram-se não emersos do pericarpo. A detecção da de germinação pode, então, requerer uma inspeção detalhada das sementes (BAUER \& BLACK, 1983).

Além dos prejuízos à qualidade industrial dos grãos, a germinação em pré-colneita pode depreciar o produto, a ser utilizado como semente, por afetar o desempenho fisiológico e o potencial de armazenamento. Os resultados obtidos por ELIAS \& COPELAND (1987) indicam que - número de sementes brotadas, bem como o estádio do processo de germinação atingido, relacionam-se com a porcentagem de germinação do lote e que, com o aumento da taxa de brotamento, o desempenho no campo e a produtividade, subsequentes, ficam prejudicados.

Durante o periodo de criptobiose, a continuidade do crescimento embrionário fica adiada para a ocasião da germinação; o período no qual uma semente quiescente permanece potencialmente apta a germinar, depende de fatores filogenéticos e ecológicos. A duração da viabilidade da semente quiescente pode, entretanto, ser alterada pelas condicões ambientais a que esteja exposta durante a fase de criptobiose, o que demonstra que a 
comunicação fisiológica entre a semente quiescente e o exterior, não está totalmente interrompida e que mecanismos de sobrevivência e de deterioração atuam no decurso da criptobiose (LABOURIAU, 1983).

Os componentes fisiológicos e bioquímicos, da qualidade da semente por ocasião da colheita, podem ser considerados como os primeiros fatores determinantes do comportamento das sementes durante as etapas subsequentes do armazenamento e da emergência no campo (ELLIS \& ROBERTS, 1980); representam, portanto, o ponto inicial, a partir do qual, alguma variação do estado da semente ocorre em sequência à deterioração (DELL'AQUILA \& TRITTO, 1991). A qualidade das sementes na ocasião da colneita depende, portanto, das condições ambientais do campo durante o desenvolvimento, a maturação e o "armazenamento" na planta mãe ( KNITTLE \& BURRIS, 1976; SHANDS et al., 1976; TEKRONY et a 1., 1979).

2.2. A hidratação e o processo de germinação de sementes

A embebição de água, na semente madura viável e não dormente, promove uma reativacão dos sistemas metabólicos existentes, suplementada pela sintese de novos componentes, que conduzem à expansão e à divisão celulares enquanto a plântula se estabelece. A mobilização de substâncias de reserva é um componente essencial deste último evento; mudanças quantitativas e qualitativas em 
enzimas catabólicas, particularmente nos órgãos de reserva (endosperma, perisperma, e cotilédones) são eventos comumente observados (KERMODE et al., 1986).

Durante o processo de germinação, a absorção de água ocorre em duas fases, de expressiva hidratação, separadas por outra de aparente repouso. A primeira fase acha-se associada com a embebição sendo, aparentemente, um processo físico e, a segunda, com o crescimento da radícula (HEGARTY, 1977a).

CHING (1972) descreveu, para o processo de germinação, três fases distintas com trechos de superposição: a primeira envolve a hidratação e a reativação funcional dos sistemas existentes, acompanhada, provavelmente, do início do metabolismo basal, do aumento no conteúdo de ATP e da síntese de proteína; a segunda fase, identifica a sintese de enzimas e organelas orientadas para o catabolismo das reservas; a terceira fase compreende a sintese de novos componentes celulares e é associada com a emergência da raiz primária.

Da mesma forma, BEWLEY \& BLACK (1985) consideram que a germinação ocorre de acordo com um padrão trifásico. Durante a primeira fase (I), com a hidratação dos tecidos e o aumento da permeabilidade dos tegumentos às trocas gasosas, a respiração e as demais atividades metabólicas são intensificadas, viabilizando o fornecimento de energia e de nutrientes necessários para o 
reinicio do crescimento do embrião. Esta fase caracterizase por uma rápida absorção de água decorrente do gradiente de potencial hídrico estabelecido, entre forças mátricas dos constituintes da semente e o substrato circundante, podendo ocorrer independentemente da semente ser dormente, viável ou não; é acompanhada pela liberação de gases e rápida lixiviação de materiais como açúcares, ions, ácidos orgânicos, aminoácidos que podem estimular o desenvolvimento de microrganismos (ROBERTS, 1981; SIMON, 1984; MARCOS FILHO, 1986).

A segunda fase (II) caracteriza-se por reduções na velocidade e na intensidade da absorção de água; a sua duração é variável segundo a espécie considerada, a condição fisiológica da semente e a temperatura ambiente (BEWLEY \& BLACK, 1978). O trigo, entre outras espécies, praticamente não apresenta esta fase (SIMON, 1984; MARCOS FILHO, 1986); as sementes mortas, ou em estado de dormência, mantém este nível de desidratação, mas não atingem a fase seguinte. Embora a absorção de água possa ser desprezível durante esta fase, a semente não está fisiologicamente inativa (CHING, 1972; BERRIE \& DRENNAN, 1971).

A terceira fase (III) é caracterizada pelo crescimento visivel do eixo embrionário, estando associada a significativos incrementos na taxa de absorção de água e na atividadé respiratoria; a ruptura dos tegumentos, ou 
coberturas da semente, pode ser resultante da pressão exercida pelo aumento do volume da semente através da elongação do eixo embrionário (BEWLEY \& BLACK, 1985; MARCOS FILHO, 1986). A entrada de água é promovida, fundamentalmente, pela raiz que, geralmente, é emitida antes da parte aérea (SIMMONS, 1987; SILVA, 1989)。

Para a continuidade do crescimento da raiz primária, é necessário que ocorram a extensão e a divisão celulares, de forma isolada ou simultânea (BERLYN, 1972). ROGAN \& SIMON (1975), descreveram um crescimento radicular, inicialmente lento, acelerando-se com o inicio da mitose.

A coincidência entre a divisão e a elongação celulares tem sido encontrada em aveia, em tomate e em alface a $26^{\circ} \mathrm{C}$ (HEGARTY, 1978). Contudo, HABER \& LUIPPOLD (1960), observaram que, a divisão e a elongação celulares, não são, necessariamente, sincronizadas, podendo ser descompassadas pela ação de temperaturas baixas $\left(10^{\circ} \mathrm{C}\right.$, retardando a mitose), ou por estresses hídricos. $(-1,0$ a $-1,3 \mathrm{MPa}$, atrasando a elongação). Sob condições extremas (sementes irradiadas severamente), plântulas de algumas espécies são capazes de fixar $\mathrm{CO}_{2}$ e aumentar de peso de matéria seca, mesmo que a mitose tenha sido completamente suprimida (BERLYN, 1972). A protusão da radícula pode ser devida à elongação celular combinada com a divisão celular ou, unicamente, à 
elongação celular resultando na "falsa germinação" (HEGARTY, 1978).

Os fisiologistas, geralmente, admitem a protusão da radícula como sendo o momento em que a germinação é concluída; os tecnologistas de sementes, por out ro lado, consideram, germinadas, somente as sementes que, ao serem examinadas, no teste de germinação, apresentem as características necessárias ao estabelecimento no campo (MATTHEUS \& POWELL, 1986).

Apesar de muitos autores usarem a emissão radicular para definir o final da germinação, o evento não garante que a semente tenha capacidade para o estabelecimento da plântula sendo, portanto, um critério limitado na avaliaçạ̃o desse processo fisiológico (PRISCo \& O'LEARY, 1970).

Por outro lado, a utilização dos resultados do teste de germinação, para fins de semeadura no campo onde, normalmente, não são encontradas as condições favoráveis utilizadas no laboratório, tem conduzido a erros. Estresses físicos (temperaturas extremas, excesso ou déficit de água, salinidade, encrostamento do solo) e biológicos, incluindo a ação de patógenos e de insetos, podem afetar adversamente a germinação e o desenvolvimento da plântula. As diferenças na capacidade de lotes de sementes, igualmente aptos a germinar, em estabelecer plântulas sob condições diferentes das ótimas, têm sido 
referidas como devidas ao vigor das sementes ( BRADFORD, 1986; MATTHEUS \& POWELL, 1986; MOTTA, 1986).

2.3. Efeito da secagem durante o processo de germinação

São de ocorrência comum, no campo, as situações de déficit hidrico em que a hidratação das sementes ocorre, sem que haja a germinação completa e o subsequente estabelecimento da planta. Estas sementes são embebidas a um nivel que não permite o desenvolvimento da plântula, embora a emissão radicular possa ou não haver ocorrido. As sementes, neste estado, poderão tolerar a condição de estresse de umidade e, na supressão desta, continuar o processo de estabelecimento ou morrer por causas fisiológicas ou patológicas (HEGARTY, 1977a).

o estresse de água pode resultar no atraso, na redução ou, ainda, no impedimento da germinação. Tem sido sugerido que a semente, atingindo um nivel critico de hidratação, procederá no sentido da germinacão plena; por outro lado, sabe-se que alterações fisiológicas ocorrem, sob hidratação parcial, quando a emissão radicular é impedida (HEGARTY, 1977b).

A germinação completa pode ser impedida em potenciais de água no solo superiores ao do ponto de murcha permanente (HEGARTY, 1978). A germinação parcial, causada por limitações na disponibilidade hídrica, pode acontecer, em algumas espécies, sem o comprometimento da 
viabilidade (WATT, 1982). Estudando o efeito de diferentes potenciais de água na germinacão de gramíneas, WATT (1974) observou a existência de um estádio, intermediário na germinação, no qual a semente conserva seu potencial de germinabilidade, mesmo quando submetidas às condições secas; denominou este fenômeno de "hidropédesis", para distingui-lo da germinação propriamente dita, considerando-o importante mecanismo ecológico de adaptação em algumas espécies.

HEGARTY (1978) elaborou uma extensa revisão, na qual levanta as respostas das sementes mantidas sob diferentes niveis de hidratação. A inibição da germinação, em certos niveis de estresse hídrico, é semelhante à de várias formas de dormência e, os mecanismos que governam a iniciação na elongação celular, são sugeridos como uma possivel mecanismo de controle do processo de germinação.

CHEN et a1. (1968), verificaram que sementes de trigo, desidratadas 48 horas após o início da hidratação, não germinavam quando reidratadas; os autores correlacionaram o estádio de sensibilidade à desidratação com a replicação do DNA e a transcrição do RNA mensageiro. DELTOUR \& JACQMARD (1974), por sua vez, encontraram que a desidratação de sementes de milho, após 45 a 75 horas de embebição, reduziu progressivamente a porcentagem de germinação; observaram, ainda, que a sensibilidade à 
secagem relacionou-se à síntese de DNA nuclear e à duplicacão do genoma.

Em sementes de ervilha, a resistência à desidratação decresce na medida em que a hidratação avança; este fenômeno, aparentemente, decorre das consequências fisiológicas provenientes do acúmulo de água nos vacúolos citoplasmáticos (SUTCLIFFE \& BRYANT, 1977). BERRIE \& DRENNAN (1971) sugerem que a habilidade das sementes, em superar a desidratação, é perdida quando a hidratação dos vacúolos do embrião se processa.

Em revisão sobre as injúrias celulares devidas ao congelamento, MERYMAN (1974) argumentou que o dano celular pode não ser o resultado da concentração de um soluto especifico, mas parece estar relacionado com a redução do volume celular após o congelamento; há a possibilidade de que a célula e, particularmente, as membranas, sejam danificadas mecanicamente com a redução de tamanho abaixo de um valor crítico. Tem sido sugerido, ainda, que há uma resistência mecânica, à mudança de volume nas células, associada com a membrana; como resultado, o contato da célula, com potenciais hídricos externos inferiores ao seu, gera um gradiente de pressão através da membrana que, por sua vez, pode ter a permeabilidade alterada (sítio primário de danificação). Este fato permite o influxo de solutos extracelulares e a perda da estabilidade das macromoléculas da membrana, com 
decorrentes eventos degradativos geradores de mudanças irreversiveis (HEGARTY, 1978; MCKERSIE \& TOMES, 1980).

A dessecação, por afetar diretamente o volume nuclear da célula e os ambientes iônico e osmótico da cromatina, pode causar um comando de abertura ou fechamento de áreas genéticas. Se esta hipótese for correta, é possivel, por analogia com a semente em maturação, que o embrião, em algum estágio durante a hidratação no processo da germinação, possa perder sua adaptação à dessecação e sofrer danos se submetido à desidratação; assim, a secagem, em momentos específicos da hidratação, pode causar mudanças nas respostas à reidratação subsequente (KERMODE, et a1.,1986).

A hidratação, inicialmente, aumenta a capacidade do embrião sintetizar proteína e RNA; estas mudanças, que ocorrem nos estádios iniciais da germinação, podem ser mantidas na desidratação e no armazenamento subsequentes. Numa série de 8 ciclos de hidrataçãodesidratação, a atividade da a-amilase foi sucessivamente acumulada, na hidratação, sem retrocessos na desidratação. Por outro lado, sementes, dispostas na superficie do solo, mostraram elevação nos níveis de ATP após a hidratação, com decrescimo, posterior, sob estresse hídrico (HEGARTY, 1978). MARCUS et al.(1966) e CHEN, et al. (1968) mostraram que a dessecação não destroi a atividade ribossômica em embriões de trigo; 
adicionalmente, verificaram que, a desidratação, após periodos de 24 horas de hidratação, estimulou a transcrição de RNAm; contudo, quando o pré-condicionamento foi de 72 horas, houve uma quebra do DNA, além de uma transcrição imperfeita do RNA.

MAY et al. (1962) sugerem que o último estádio, em que as sementes podem ser secadas sem o surgimento de danificações metabólicas, é o momento da emergência da radícula, quando se iniciam a expansão e, possivelmente, a divisão celulares. A desidratacão de sementes de aveia, anteriormente aos primeiros sinais visiveis da germinação, não apresentou efeito na taxa de germinação subsequente (AKALEHIYWOT \& BEWLEY, 1977). HEGARTY (1977b) confirmou que sementes germinadas, de repolho e cenoura, podem sobreviver à desidratação e subsequente reidratação, especialmente quando o desenvolvimento das plântulas não atingiu estádios avançados. O autor relata que, mesmo em condições uniformes de solo, ocorrem variações na resposta ao estresse hidrico entre os individuos dentro da população de um lote de sementes.

CARCELAR \& SORIANO (1972), no entanto, secaram sementes de trigo, com a emergência radicular presente, sem que fossem constatados efeitos deletérios na qualidade fisiológica; mesmo quando o processo foi realizado repetidamente, a viabilidade foi mantida em 
algumas sementes. Plântulas, em estádios avançados da germinação, podem ser desidratadas sem que haja a morte; a retomada do crescimento, contudo, pode se dar a partir de iniciações secundárias (MILTHORPE, 1950; HEGARTY, 1977a)。

Assim, alguns mecanismos fisiologicos, associados com a preparação da semente para a germinação, parecem persistir na desidratação se não forem impedidos por danificação celular ou por alguma forma de dormência secundária (BERRIE \& DRENNAN, 1971).

No campo, as condições de umidade estão continuamente mudando e, com isso, as sementes podem experimentar uma série de ciclos de hidrataçãodesidratação. É comum, portanto, que a falha na germinação e no estabelecimento de plântulas seja devida à deficiência hídrica do solo. Contudo, o caminho que leva à morte das sementes está pouco esclarecido. A morte pode ocorrer, antes da germinação, decorrente de causas fisiologicas ou patológicas; pode, ainda, acontecer como resultado da desidratação, ou do ataque de patógenos à plântula após a emergência da raiz primária (HEGARTY, $1977 a b$ e 1978; LUSH \& GROVES, 1981).

outro aspecto a ser considerado, é a atividade de microrganismos em sementes, parcialmente embebidas, no solo. Nesse sentido, WALLACE (1960) concluiu que os fungos estão envolvidos com a morte de sementes de trigo sob condições de estresse hidrico. CHRISTENSEN 
(1973) sugere que, no solo, os fungos de armazenamento, mais que os fungos de campo, parecem ser os responsáveis pelas perdas e que, a condição encontrada no campo, pode se assemelhar à sementes mantidas em condições de equilíbrio com umidades relativas elevadas durante o armazenamento.

Em um lote de sementes, sob situações de estresses hidricos crescentes, a germinação se reduz progressivamente, até que nenhuma semente possa germinar; nestas condições, sementes de baixo vigor podem requerer maior conteúdo de água para germinar, quando comparadas com as de alto vigor; por outro lado, a deterioração das sementes reduz a amplitude de variação das condições nas quais a semente pode germinar. Assim, não é o nível de hidratação, exclusivamente, que governa a possibilidade de germinação (ABDUL-BAKI \& ANDERSON, 1972; HEGARTY, 1978).

2.4. Processos fisiológicos relacionados ao teor de água das sementes durante o armazenamento

Processos fisiológicos distintos ocorrem em função do teor de água presente na semente durante o armazenamento; embora não sejam totalmente compreendidos, são reconhecidos através de seus efeitos na constituição da semente ou na performance durante a germinação. Em sementes "muito secas", os danos podem ocorrer como resultado da remoção excessiva de água; em sementes 
"secas", a deterioração ocorre, apesar de ser considerada como minima; em sementes "ligeiramente úmidas", tanto o metabolismo quanto a deterioração aumentam com o conteúdo de umidade; o desenvolvimento do eixo embrionário pode ocorrer no estado de embebição "parcial"; contudo, há a necessidade de teores de água mais elevados para que a extensão e a divisão celulares permitam a continuidade do crescimento da radicula (HEGARTY, 1978).

A conservação da viabilidade das sementes colnidas depende de fatores como a temperatura e o seu conteúdo de água (ROBERTS, 1981 ; ELLIS \& ROBERTS, 1982; IBRAHIM \& ROBERTS, 1983). No que se refere a esses fatores, ELLIS \& ROBERTS (1980) estabeleceram a seguinte equação para para prever o comportamento fisiológico das sementes armazenadas ao ar:

$$
\log _{10}\left(P_{50}\right)=K_{V}-m \cdot c_{1}-t \cdot c_{2} \text {, onde: }
$$

$P_{50}=$ tempo para que a amostra perca a metade da viabilidade inicial;

$\mathrm{m}=$ conteúdo de água da semente;

$\mathrm{t}=$ temperatura $\left({ }^{\circ} \mathrm{C}\right)$;

$K_{v}, C_{1}$ e $C_{2}=$ Constantes relativas à espécie.

Além de aglutinar uma série de resultados experimentais relativos ao armazenamento de sementes expostas ao ar livre, essa expressão indica a importância das temperaturas e umidades baixas na adequada conservação das sementes ortodoxas. 
A secagem excessiva, no entanto, pode danificar as sementes (HARRINGTON, 1972; CHING, 1973; WOODSTOCK et al., 1976). HARRINGTON (1972) sugere que a água nas sementes pode ser descrita em termos de três categorias: água livre, água intermediária e água de camada monomolecular. Com a secagem, a semente perde primeiramente a água livre e, a seguir, a àgua intermediária; posteriormente, a água da camada monomolecular, que envolve as macromoléculas, é progressivamente removida deixando de exercer a sua função protetora contra os processos oxidativos.

A oxidação dos lipídios, pode promover uma reação em cadeia favorável à produção de radicais livres muito reativos. Fundamentalmente, estes danos têm origem na ativação de enzimas, como a liase do hidroperóxido que, atacando os ácidos graxos oxigenados, liberam radicais livres capazes de reagir e formar produtos secundários tóxicos; por sua vez, esses produtos podem inibir a respiração, a sintese de proteína e de DNA ou provocar a desnaturação de macromoléculas (HEGARTY, 1978). Mesmo em condições de umidade ideais para o armazenamento, os danos nas membranas celulares podem ocorrer através de um ataque lento, porém consistente, do oxigênio à camada lipídica formando peróxidos, ácidos graxos oxigenados e radicais livres. Os radicais livres podem reagir com outras moléculas próximas, danificando- 
as. Os danos podem ser acumulados, manifestando-se por ocasião da hidratação das sementes (HEGARTY, 1978).

2.4.1. Mudanças associadas à deterioração das sementes durante o armazenamento

Existem evidências de que a deterioração, em sementes "ligeiramente úmidas", seja um processo fisiológico; CHRISTENSEN (1973), contudo, cita a atividade fúngica como a causa primária da deterioração de sementes. HARRISON \& PERRY (1976), por outro lado, apresentaram causas eminentemente fisiológicas para explicar a deterioração de sementes de cevada mantidas em condições "Iigeiramente úmidas" de armazenamento; neste caso, a deterioração, detectada no início do declínio do vigor e da viabilidade, precedeu a atividade dos fungos que, portanto, podem não ser a causa primária da deterioração.

A semente, por ser higroscópica, apresenta a propriedade de ganhar ou perder água, para o meio em que se encontra, até alcançar o ponto de equilíbrio higroscópico (TOLEDO \& MARCOS FILHO, 1977). O conteúdo de umidade de equilíbrio, ótimo para o armazenamento a seco, representa aquele em que é minimizada a deterioração promovida pela umidade e, ao mesmo tempo, evita os danos causados pela desidratação excessiva (ROBERTS, 1972a; EDWARDS, 1976; ANDERSON \& BAKER, 1983).

As mudanças que ocorrem durante 0 
armazenamento, associadas à deterioração, conduzem ao retardamento da germinação, reduzem a taxa de crescimento das plântulas, diminuem a tolerância às condições adversas de germinação e, finalmente, levam à perda da viabilidade (ABDHUL-BAKI \& ANDERSON, 1973; DELOUCHE \& BASKIN, 1973). Antes da perda da viabilidade, no entanto, uma série de transformações físicas, fisiológicas e bioquímicas podem ocorrer nas sementes; o somatório dessas transformações que, em última instância, conduz à perda da viabilidade, é referido como deterioração (DELOUCHE, 1973 ; DELOUCHE \& BASKIN, 1973; HARRINGTON, 1973; MCGEE, 1983; MOTTA, 1986).

ROBERTS (1973) descreveu algumas das principais mudanças observadas em sementes durante a deterioração: danificações citológicas, incluindo danos nos cromossomos e nos ribossomos, sintomáticas da degradação geral dos ácidos nuclêicos; danificações em outras organelas celulares, sintomáticas da degradação geral das camadas 1ipo-protêicas; danificações na membrana celular; alterações na ação das enzimas, com redução das atividades relacionadas com a oxi-redução e elevação daquelas relacionadas com a hidrólise; mudanças nos constituintes celulares, incluindo proteínas, ácidos graxos, açúcares e reguladores do crescimento; decréscimo na capacidade de incorporação de aminoácidos e açúcares isotopicamente marcados. Algumas dessas mudanças são 
aceleradas pela ação de microrganismos.

Uma importante hipótese, relacionada à deterioração, diz respeito aos danos verificados nas membranas celulares após um periodo de armazenamento prolongado. Sementes velhas, quando colocadas para embeber, perdem solutos mais rapidamente do que as mais novas, sugerindo que as membranas possam, com o tempo, perder a capacidade de reter substâncias no interior da célula (BASU, 1976; ROBERTS, 1981). Este sintoma, característico do avanço da deterioração, é evidente ao ponto de permitir que medidas de eletrocondutividade e de concentração de açúcares, do meio de hidratação das sementes, sejam empregadas para avaliar a viabilidade (MAGUIRE, 1973; SIMON, 1974).

o estudo da estrutura de membranas das organelas celulares em embriões vegetais, ao microscópio eletrônico, revela que ocorre, com o tempo, uma perda da integridade intimamente associada ao processo de deterioração; provavelmente, este seja o primeiro evento da sequência que ocorre durante esse processo (DELOUCHE \& BASKIN, 1973; KOOSTRA, 1973 ; LABOURIAU, 1983).

o sistema de membranas celulares inclui o plasmalema (que delimita o conteúdo celular), o tonoplasto (ou a dos vacúolos) e as membranas do aparelho de Golgi, do retículo endoplasmático, dos peroxissomas, dos glioxomas, dos esferossomas, dos plastídeos, das 
mitocôndrias e do núcleo, (ABDUL- BAKI \& BAKER, 1973).

Entre as mudanças bioquímicas, associadas às mudanças nas propriedades das membranas celulares, podem ser citadas: a elevação nas taxas de açúcares, aminoácidos e sais inorgânicos lixiviados, presumivelmente devida ao aumento da permeabilidade do plasmalema; redução na capacidade fosforilativa das mitocôndrias, como consequência de alterações em suas membranas; redução na sintese de proteínas e de carboidratos, possivelmente relacionada à desorganização das membranas do retículo endoplasmático e do aparelho de Golgi; perda da permeabilidade seletiva do tonoplasto que delimita os vacúolos (ABDUL-BAKI \& BAKER, 1973). Quando a semente deteriorada se hidrata, as enzimas hidroliticas dos vacúolos são difundidas para o interior do citoplasma através de falhas no tonoplasto, o mesmo acontecendo com ás fosfatases ácidas e com os lipídios que, nesta situação, podem coalescer. o resultado do fenômeno é uma desorganização geral capaz de provocar a morte da célula (ABDUL-BAKI \& BAKER, 1973; HALLAN, 1973; VILLIERs, 1973; LABOURIAU, 1983; DONI FILHO, 1992).

A permeabilidade seletiva da membrana celular é fundamental ao funcionamento da célula viva e à manutenção das condições fisiológicas intracelulares satisfatórias. Esta propriedade determina as substâncias que podem entrar na célula, incluindo as necessárias para 
a manutenção dos processos vitais e da síntese de novas substâncias; paralelamente regula a excreção de água e de refugos metabólicos (DE ROBERTIS \& DE ROBERTIS Jr., 1986).

A permeabilidade das membranas a um soluto depende da fase de vida da célula e pode ser alterada pelo ambiente; assim, a senescência ou a exposição a condições de estresse, como a desidratação, podem alterar a sua permeabilidade e, permitir a perda de solutos no estádio inicial da embebição (SIMON, 1974; BEWLEY \& BLACK, 1985). A perda de solutos, para o meio de embebição, favorece e estimula a ação de microrganismos, o que contribue para o agravamento da deterioração. (ABDUL-BAKI \& BAKER, 1973; CHRISTENSEN \& KAUfMANN, 1969; McGeE, 1983). Portanto, a dessecação, naturalmente imposta às sementes após a maturação fisiológica, não deve ocorrer sem algum prejuízo funcional (LABOURIAU, 1983).

2.4.2. At ivação fisiológica e mecanismos de reparo de organelas e membranas celulares

WALLACE (1960) mostrou que, em sementes de trigo mantidas em solos com diferentes potenciais hídricos, a deterioração foi maior sob um determinado potencial de água, decrescendo, tanto em solos mais úmidos, quanto em mais secos. o comportamento foi repetido em vários tipos de solo. Algumas sementes, apesar de não germinadas, tinham teores de água próximos daquele que 
permitiria a germinação e se encontravam metabolicamente, ativadas; o nível da deterioração foi altamente dependente da espécie e do lote de sementes.

As respostas das sementes aos diferentes niveis de hidratação podem, portanto, variar entre a germinação, de um lado, e a deterioração e morte de outro, embora algumas possam permanecer dormentes e viáveis no solo por muitos anos quando completamente hidratadas (VILLIERS \& EDGCUMBE, 1975; HEGARTY, 1978).

Uma descoberta importante, relacionada com a deterioração, foi a de que sementes quiescentes, armazenadas ao ar livre por longo periodo, podem produzir plântulas com aberrações cromossômicas; e que, durante o crescimento dessas plântulas, pode ocorrer a eliminação progressiva das células com aberrações cromossômicas pelo fato das mesmas se dividirem mais lentamente do que as demais (ROBERTS, 1972b). Nessa linha de pesquisa, há informações de que, no caso das sementes conservadas embebidas, as mutações surgem em taxas significativamente menores (VILLIERS, 1973; HEGARTY, 1978). o fato da taxa de mutações em sementes armazenadas secas, ser superior à das sementes embebidas, contribuiu para que fossem investigados outros tipos de mecanismos atuantes na deterioração das sementes (VILLIERS \& EDGCUMBE, 1975).

Outras pesquisas têm revelado que as membranas celulares se recuperam, tornando-se estáveis 
dentro de pouco tempo após o início da embebição. Alguns autores sugerem que, com a absorção de água no início da germinação, reduz-se a reação do oxigênio com a camada lipidica e, com isso, surge a possibilidade de reestruturação das membranas (HARRINGTON, 1972 e 1973; HARMAN \& MATTICK, 1976; WILSON JR. \& MCDONALD JR., 1986). HEGARTY (1978), sugere que, com a elevação do conteúdo de água nas sementes, deve haver um ponto de transição, em que os mecanismos de reparo celular predominem sobre os de deterioração. Esse aspecto do processo da deterioração das sementes deslocou o interesse para duas linhas correlacionadas de pesquisa: a dos mecanismos de origem das lesões às biomembranas e a dos correspondentes processos de reparo (VILLIERS, 1973 ; VILLIERS \& EDGCUMBE, 1975; HEGARTY, 1978).

SIMON \& RAJA-HARUM (1972), trabalhando com embriões de ervilha, observaram que a velocidade de lixiviação era reduzida, com o passar do tempo, durante a embebição. Por outro lado, verificaram que, embriões previamente umedecidos ou colhidos após a maturidade e antes da desidratação natural, não perdiam eletrólitos quando imersos em água. Segundo os autores, a taxa de perda dos solutos parecé estar relacionada com a posição das células na semente. As mais externas perdem material primeiro mas, à medida em que absorvem água, regeneram suas membranas reduzindo as perdas. As mais internas, 
sujeitas a um umedecimento mais lento em função da sua localização, liberam solutos durante um prazo mais dilatado; contudo, a liberação dos solutos, para o meio de embebição externo à semente, fica atenuada pelas dificuldades impostas pelos tecidos intermediários existentes no percurso. As sementes deterioradas, normalmente, liberam maior quantidade de substâncias; porém, nas sementes mais vigorosas, o restabelecimento da integridade das membranas celulares pode ser efetivado rapidamente, limitando a lixiviação de substâncias para o meio de hidratação. Para o caso das membranas mitocondriais, no entanto, BEWLEY \& BLACK (1985) afirmam que a recuperação demanda um período de tempo superior, por exigir um efetivo mecanismo de reparo bioquímico.

Uma hipótese, proposta por, SIMON \& MILLS (1983) e SIMON (1984), afirma que, nas sementes secas, as membranas encontram-se desorganizadas e não apresentam a característica de semi-permeabilidade; esta condição surge, apenas, com a embebição. De acordo com esta hipótese, a arquitetura adotada pelos fosfolipídios da membrana, em baixos teores de água, confere a porosidade que permite ampla permeabilidade aos solutos. Argumentase que, alta permeabilidade das membranas celulares, em sementes secas, é devida ao fato da camada fosfolipídica persistir em estrutura hexagonal. Na embebição, as membranas tendem a recuperar a estrutura lamelar semi- 
permeáve 1 (SIMON, 1974; WEBSTER \& LEOPOLD, 1977; BRANLAGE et a 1., 1978; KNYPL, et a 1., 1980).

Tem sido observado que, em sementes secas, as mitocôndrias são pouco diferenciadas e deficientes em desidrogenase do malato; contudo, com a embebição, tornamse ricas em proteína e lipidios e, biologicamente, ativas (NAWA \& ASAHI, 1971; ROBERTS, 1973).Além disso, é sugerido que, fisiologicamente, o inicio da germinação depende do acoplamento da respiração ao crescimento. Contudo, enquanto o crescimento da radicula pode ser vinculado ao aumento da respiração, a respiração pode acontecer, expressivamente, na ausência do crescimento; exemplo deste caso ocorre em sementes que, impedidas de germinar, utilizam a energia proveniente da respiração em processos metabólicos endergônicos ( HABER \& LUIPOOLD, 1960; CHING \& FOOTE, 1961; CHEN \& VARNER, 1970; HEGARTY, 1977a). Contudo, as relações de comprometimento da energia proveniente da respiração, com os mecanismos de reparo celular e com o desenvolvimento embrionário, não se encontram suficientemente esclarecidas (HEGARTY, 1978).

No caso de sementes ortodoxas, o padrão de deterioração, que precede a morte, é o mesmo, e não depende do periodo de sobrevivência das sementes. Alguns danos podem ser revertidos com a hidratação das sementes, provavelmente através de mecanismos de reparo celular. Entretanto, os danos mais severos, desenvolvidos na fase 
final do processo de deterioração, são, de forma geral, irreversiveis (ROBERTS, 1981).

2.5. Tratamentos de Hidrat ação/Desidrat ação

Pesquisas com sementes dormentes (VILLIERS \& EDGCUMBE, 1975) e não dormentes (AUSTIN et al., 1969; HEGARTY, 1970, HEYDECKER et al., 1973) e, revelam que ciclos de embebição e desidratação, durante o armazenamento, podem reparar os danos deteriorativos e que sementes dormentes, embebidas, podem ser armazenadas sem deterioração. Isto indica, a existência de efeitos positivos da umidade na atividade metabolica das sementes, quando mantidas em condições que previnam a germinação.

Portanto, tratamentos de pré semeadura, que envolvem a iniciação metabólica através da hidratação das sementes, considerados como de envigoramento, têm surgido com a finalidade de, alterando o estado fisiologico da semente, reduzir o tempo e elevar a taxa de germinacão, produzir uniformidade na emergência e elevar a capacidade das plântulas em resistir aos efeitos adversos do ambiente. (BASU, 1976; DEY (PATHAK) \& MUKHERJEE, 1988).

A possibilidade de envigoramento baseia-se na ação de mecanismos de reparo celular, que ocorrem nas sementes durante as fases iniciais da germinação; a existência destes mecanismos é defendida por alguns pesquisadores e questionada por outros (TILDEN \& WEST, 
1985). A hipótese do reparo inclui a reorganização dos fosfolipidios, que ocorre durante a hidratação, e o reparo metabólico subsequente, como sugerem os trabalhos de VILLIERS (1973 e 1974), SIMON (1974) e VILLIERS \& EDGCUMBE (1975). Entretanto as evidências experimentais, para a confirmacão do reparo em sementes embebidas, são escassas (TILDEN \& WEST, 1985).

Duas hipóteses têm sido sugeridas para justificar o aumento da performance de sementes submetidas ao "envigoramento": a restauração da integridade das membranas, perdida durante o processo de secagem nas sementes maduras, e o incremento na disponibilidade de metabólitos prontos para serem utilizados nos processos de germinação e crescimento (KNYPL \& KHAN, 1981). o rearranjamento estrutural das membranas, resultante da embebição, é manifestado pela redução no vazamento de eletrólitos das sementes, que pode ser o fator responsável pelo aumento do vigor (SIMON, 1974; WEBSTER \& LEOPOLD, 1977 ; BRANLAGE et a1., 1978 ; KNYPL, et a1., 1980). A teoria, sobre a ação dos tratamentos de hidrat ação/desidrat ação, sugere, ainda, que os mesmos promovam aumento nas sinteses de proteína e de ácidos nuclêicos, elevação na atividade mitocondrial, com mudanças sequenciais associadas à elasticidade e à viscosidade do protoplasma (HENCKEL, 1964; HEYDECKER, 1972; HEGARTY, 1978)。 
VILLIERS \& EDGCUMBE (1975) introduziram o conceito do reparo das bioorganelas, durante a hidratação da semente, posteriormente confirmado por ROBERTS (1981) e OSBORNE (1982). A neutralização dos radicais livres e das reações de peroxidação dos lipídios pode, também, operar nos tratamentos de hidratação-desidratação (PRIESTLEY \& LEOPOLD, 1983; BUCHVAROV \& GANTCHEFF, 1984; DEY (PATHAK) \& BASU, 1985; MANDAL \& BASU, 1987b).

As metodologias empregadas nestes tratamentos podem diferir entre si. As variações residem nas formas de fornecimento de água (equilibrio higroscópico com a atmosfera; embebição em substrato; imersão em água pura, em soluções salinas ou osmóticas), na opção pela realização de secagem subsequente à hidratação, no número de ciclos de hidratação e desidratação, na duração do período de hidratação, no nivel de hidratação e no estádio da germinação atingido durante o condicionamento (HANSON, 1973; HEYDECKER, 1973/74; HEYDECKER \& COOLBEAR, 1977; HEGARTY, 1978; TONKIN, 1979; KNYPL \& KHAN, 1981; MANDAL \& BASU, 1987b).

Entre os primeiros métodos empregados no envigoramento, o denominado "hardening" baseava-se na alternância de embebicão e secagem das sementes antes da germinação haver sido completada. As propriedades protoplasmáticas, afetadas através desse método, são a viscosidade, a capacidade hidrofilica e a elasticidade; 
as plantas resultantes podem adquirir maior capacidade de reter água, além de acréscimos nas reações de síntese e na taxa fotossintét ica (HENCKEL, 1964; BRADFORD, 1986)。

A proposta original sugeria que a hidratação fosse responsável pelo efeito "hardening"; contudo, HANSON (1973) mostrou que o efetivo envigoramento da semente ocorre no período de embebição sendo, subsequentemente, fixado pela secagem. Os resultados dessa técnica têm apresentado, mais expressivamente, aceleração na germinação em várias espécies (BLEAK \& KELLER, 1970; COCKS \& DONALD, 1973; A-AS-SAQUI \& CORLETO, 1978; WATT, 1978; BRADFORD, 1986; DALIANIS, 1989). Além disso, trigo e milho tiveram ganhos de produtividade quando suas sementes foram submetidas ao processo de "endurecimento" (HENCKEL, 1964).

HEYDECKER et a $1 . \quad(1973 / 74)$ obtiveram envigiramento usando soluções osmóticas que, apesar de inibidoras da emergência da radícula, permitiam a hidratação suficiente para que o metabolismo ocorresse. Soluções salinas eram, inicialmente, usadas para esse propósito (BRADFORD, 1986) mas, HEYDECKER (1973/1974), usou polietileno glicol como um soluto quimicamente inerte. As sementes em contacto com uma solução aquosa com essa substância, absorvem água até que seja estabelecido o equilíbrio com o potencial hídrico da solução. o potencial hidrico e, consequentemente, o conteúdo de água da 
semente, pode ser ajustado de modo que permita à semente passar pelos processos preparatórios, essenciais à germinação, mas que iniba a elongação celular e a emissão da radícula; o tratamento permite a quebra das substâncias de reserva e a sintese de materiais requeridos à germinação, possibilitando que as sementes germinem mais uniforme e rapidamente, com crescimento embrionário imediato, assim que as sementes sejam transferidas da solução osmótica para um substrato sem limitacões hídricas (HEYDECKER et a 1., 1975; BRADFORD, 1986).

BURGASS \& POWELL (1984) verificaram que, o envigoramento das sementes, não foi apenas devido ao alcance de um estádio mais avançado da germinação, uma vez que, os efeitos benéficos, ocorreram após a secagem. os efeitos benéficos, atribuidos ao envigoramento fisiológico foram, também, observados na superação de estresses durante o periodo de armazenamento, com reflexos positivos na emergência em campo e na produtividade (BASU \& RUDRAPAL, 1982) e na superação de condições desfavoráveis de campo (BLEAK \& KELLER, 1970). Geralmente, a germinação ou a emergência são mais uniformes, rápidas e elevadas após os tratamentos, especialmente sob baixas temperaturas, com o efeito mais pronunciado quando a semente não é submetida à secagem após o tratamento (HEYDECKER, 1973/74; SALTER \& DARBY, 1976; MANDAL \& BASU, 1987b; DALIANIS, 1989; NATH et a1., 1991). 
Alguns trabalhos mostraram que a germinação, sob baixas (HEGARTY, 1970; HEYDECKER et a1., 1975; KHAN \& KNYPL, 1977; SACHS, 1977) e altas temperaturas (HEYDECKER et a 1., 1975), pode ser aumentada. WILSON (1971) relacionou os efeitos favoráveis do précondicionamento, na germinação à baixa temperatura, com o aumento na atividade da a-amilase que, por sua vez, foi indicador da ação do tratamento. o requerimento fisiológico para a germinação sob temperaturas alternadas pode, também, ser removido pelo condicionamento fisiológico (HAIGHT \& GRABE, 1972). Em adição à superação das restrições de temperatura, os tratamentos de précondicionamento de sementes têm mostrado afetar a germinação subsequente sob estresses osmóticos ou salinos. A taxa de germinação de trigo, em condições salinas, foi aumentada pelo pré-condicionamento das sementes (IDRIS \& ASLAM, 1975; HEGARTY, 1978 ; DALIANIS, 1989)。

VILLIERS \& EDGCUMBE (1975) evidenciaram que - reparo celular pode ocorrer em sementes de alface totalmente embebidas. Outros trabalhos, contudo, detectaram a ocorrência do reparo em conteúdos de umidade, inferiores aos de hidratação completa, em torno de 20-25\% em sementes de cebola (WARD \& POWELL, 1983) e de $15 \%$ em sementes de alface (IBRAHIN \& ROBERTS, 1983). Alguns autores sugerem que os efeitos benéficos do précondicionamento podem ser obtidos com hidratações de curta 
duração (BASU, 1976; GOLDSWORTHY et a1., 1982; MANDAL \& BASU, 1987a). Em cevada, CHATTERJEE \& SINGH (1983) relataram, para sementes pré-hidratadas por $6 \mathrm{~h}$ numa solução de fosfato, vantagens na performance de campo.

Em aveia, BERRIE \& DRENNAN (1971) encontraram que a atividade da protease é maior, durante a germinação, em sementes tratadas por hidratação/secagem. Esta resposta foi mantida após o armazenamento e o efeito, de sucessivos ciclos de hidratação-desidratação, foi acumulativo quando a pré-hidratação foi de longa duração. Entretanto, tem sido observado, em sementes de trigo, que os tratamentos de hidratação, de longa duração, foram prejudiciais quando a secagem foi conduzida até a umidade original; além disso, o potencial de armazenamento foi adversamente afetado (MANDAL \& BASU, 1987a; NATH et al., 1991).

Vários estudos revelam que a secagem após a hidratação pode anular os efeitos benéficos provenientes do pré-condicionamento, ou provocar danos fisiológicos, dependendo do estádio da germinação em que a desidratação é realizada; foi observado, ainda, que a resistência das sementes à desidratação decresce à medida em que estas avançam no processo de germinação (HENCKEL, 1964; CHEN et a1. 1968; SALIN \& TOOD, 1968; DELTOUR \& JACQMARD, 1974 ; BEWLEY \& BLACK, 1978; HEGARTY, 1978; BRADFORD, 1986)。

SEN \& OSBORNE (1974) encontraram que a germinação, de embriões de centeio, foi aumentada por 
sementes pode, ainda, ser devido à ação da secagem imposta em estádios do desenvolvimento atingidos, pelos microrganismos, em função da hidratação precedente, e que podem ser menos tolerantes desidratação (HALLOIN, 1983).

Vários aspectos, associados ao processo de hidratacão/desidratação de sementes, permanecem pouco elucidados. O nível de hidratação e o período de duração do condicionamento fisiológico, onde os efeitos associados à deterioração podem ser revertidos pelos mecanismos de recuperação, requerem maior conhecimento. Outras dúvidas, relacionadas aos efeitos da desidratação no decorrer do processo de germinação, devem ser consideradas levando em conta que, dentro de uma população de sementes, existem diferenças individuais no estádio de desenvolvimento e no nível de tolerância à secagem. Informações adicionais são necessárias, sobre a ação do condicionamento fisiológico na atividade de microrganismos associados às sementes.

Para justificar a adoção de tratamentos em pré semeadura, os seus beneficios precisam, ser confirmados através de resultados consistentes, em termos de redução dos riscos ao desempenho das sementes, durante - armazenamento e o estabelecimento no campo; qualquer que seja o mecanismo de ação dos tratamentos, alguma forma de envigoramento, especialmente para os lotes de sementes declinaram em seu vigor, precisa estar envolvida no processo. 
tratamento de hidratação-desidratação; houve, no ent anto, uma relação inversa entre os avanços dos processos de síntese, envolvidos na hidratação, e alguns dos danos celulares detectados na desidratação subsequente; estes danos foram caracterizados como decorrentes da redução na habilidade da célula em incorporar leucina (síntese de proteína) ou timidina (replicação do DNA).

outros estudos mostraram efeitos adversos do pré-condicionamento na armazenabilidade de sementes de alto vigor (BASU, 1976; MANDAL \& BASU, 1987a; MOHAMMAD \& SUNDER, 1991; NATH et al., 1991). Além disso, sementes de trigo e de azevém submetidas ao pré-condicionamento, foram mais vulneráveis a ação de altas temperaturas do que as não tratadas e, dessa forma, passaram a ter o seu uso limitado a alguns ambientes (LUSH et al., 1981).

LUSH et al.(1981), avaliando os efeitos de ciclos de hidratação/desidratação na germinação e no estabelecimento inicial de plântulas de trigo e de azevém anual, concluiram que, embora a velocidade de germinacão, de ambas as culturas tenha sido dobrada e a dormência, na ausência de 1uz, para o azevém, tivesse sido reduzida em alguns casos, não houve nenhuma evidência de outros efeitos benéficos. Segundo os autores, nas condições de campo, a germinação precoce resultaria no avanço do periodo de crescimento da planta somente na ausência de fatores limitantes adicionais; além disso, a aceleração no 
desenvolvimento da planta seria interessante, apenas, nas culturas em que o momento da maturidade fosse critico.

Dessa forma, o pré condicionamento pode apresentar vantagens nas situações em que o periodo demandado para a germinacão interage, positivamente, com outros fatores; é o caso, por exemplo, das semeaduras em solos sujeitos à secagem prematura em que as sementes, de germinação mais rápida, apresentam maiores possibilidades ao estabelecimento de plântulas. Além disso, a rapidez na germinação pode ser vantajosa em misturas de espécies; na presença de azevém anual, por exemplo, a produtividade do trigo será menos prejudicada se a sua emergência acontecer antes da do azevém (RERKASEM et a1., 1980; LUSH \& GROVES, 1981 ; LUSH et al., 1981).

$\mathrm{Na}$ natureza, as sementes depositadas no solo sofrem ciclos de hidratação/desidratação durante a sucessão de chuvas insuficientes para a germinação; cada ciclo pode modificar o comportamento da germinação subsequente, tanto quanto nos ciclos artificialmente impostos (GRAMSHAL \& STERN, 1977; VICENT \& CAVERS, 1978).

2.6. Mecanismos de controle de patógenos em sementes

$$
\text { Alguns mecanismos, pelos quais os }
$$

cultivares diferem na resistência à deterioração de sementes estão, até certo ponto, envolvidos no controle, inibição ou eliminação de microrganismos das sementes. Por 
outro lado, os mecanismos naturais, pelos quais os microrganismos são excluídos dos embriões, são pouco conhecidos, podendo-se apenas especular sobre as possíveis bases dessa resistência (HALLOIN, 1983).

A liberação de nutrientes tem sido considerada como um fator determinante na resistência das sementes de ervilha ao ataque de fungos do solo. A estrutura e a integridade, das membranas celulares e do tegumento das sementes, parecem relacionadas, diretamente, com a perda de nutrientes e com a velocidade de embebição das sementes. SHORT \& LACY (1976) mostraram que sementes de ervilha, com elevado nível de deterioração, apresentavam alta velocidade de embebição e altas taxas de lixiviação de solutos. KRAFT (1977) observou que, embora a antocianina delfinidina fosse inibidora de Fusarium, esta ação foi revertida na presença de glucose; assim, as membranas celulares e o tegumento da semente funcionam como barreiras regulatórias da disponibilidade de nutrientes aos fungos.

A produção de fitoalexinas é um sistema de defesa sanitária, naturalmente encontrado em plantas e a sua ocorrência nas sementes tem sido pesquisada. Os exames sobre a produção de fitoalexina pelos tecidos das sementes revelam que, em todos os casos, a sua constatação se deu, exclusivamente, em teores de água próximos aos requeridos para a germinação (KEEN, 1975; PFLEGER \& HARMAN 1975a). 
PFLEGER \& HARMAN (1975b) relataram que, embora a pisatina fosse produzida em cotilédones de ervilha embebidos, isto somente ocorreu quando o conteúdo de umidade atingiu 20\%. Similarmente, fitoalexinas de algodão (gossipole hemigossipol) foram produzidas em cotilédones de sementes germinantes, ou expostas às chuvas no campo; porém, isto não ocorreu em sementes mantidas com $20 \%$ de água. Assim, embora as fitoalexinas possam ser importantes para a proteção de sementes embebidas, não parecem agir na proteção de sementes mantidas sob teores de água usualmente empregados no armzenamento (HALLOIN, 1983; PFLEGER \& HARMAN, 1975a).

Muitas sementes são reconhecidas por produzir inibidores de hidrolases, especialmente proteases, com funções pouco conhecidas. RYAN (1973) observou que muitos dos inibidores da protease, encontrados na semente, não atuam na regulação endógena da própria semente, mas inibem as proteases de outros organismos. KIRSI (1974) relatou que um inibidor de protease, proveniente de embriões de cevada, inibiu proteases de Aspergi77us. HALIM et al. (1973) observaram que inibidores da tripsina, em sementes de milho, inibiram o crescimento de fungos, o que poderia se constituir em uma forma de proteção das sementes à invasão de patógenos. Da mesma forma, HWANG et al. (1978) verificaram a liberação de inibidores de proteases e lectinas, durante 
os estádios iniciais da germinação de soja, e sugeriram que, ambos os grupos de compostos, podem servir como inibidores do crescimento de microrganismos.

As lectinas das plantas são proteínas longas que contém múltiplos sítios para ligação de carboidratos. Estes compostos têm recebido muita atenção, nos últimos anos, pela possibilidade de estarem envolvidos no reconhecimento de patógenos em vários tecidos de plantas. Tem sido sugerido que estes compostos podem ter uma função direta nos sistemas que concedem resistência aos patógenos em sementes que são fontes ricas desses compostos. MIRELMAN et a1. (1975) observaram que a lectina do germe do trigo ligou-se à extremidade das hifas de Trichoderma viride e inibiu o seu crescimento; sugerindo que a lectina possa servir como um protetor contra patógenos de trigo durante a germinação. Tem sido estudada, em outras espécies, a ação tóxica das lectinas como inibidora da sintese de proteínas em microrganismos (LIENER , 1976; PULL et a1., 1978).

Outras substâncias, que possuem uma ação anti-patogênica, têm sido encontradas em sementes com teores de água próximos do requerido ao processo de germinação (HALLOIN, 1983). Portanto, os tratamentos que envolvem a hidratação prévia das sementes, além da at ivação metabólica, podem fornecer as condições favoráveis para a ação dessas substâncias na proteção das 
sementes contra o ataque de microrganismos.

Existem evidências de que a dormência contribui para a resistência das sementes à ação dos microrganismos. Embora a dormência possa não contribuir para a resistência à degradação microbiológica, pode auxiliar na prevenção das mudanças degradativas originárias da semente. CASTOR \& FREDERICKSEN (1977) observaram que espigas de sorgo, infectadas por fusarium, tinham maior incidência de sementes brotadas do que as não infectadas; assim, os fungos podem atuar na superação da dormência e sementes, resistentes à infecção por fungos, podem ser capazes de manter a dormência e assegurar menor brotamento na espiga.

VILLIERS (1974) relatou o armazenamento seguro, de sementes de alface e de freixo verde, pela completa imersão. Não foi possivel identificar se a ausência de deterioração foi devida à dormência ou à anoxia, contudo, a sobrevivência das sementes sob essa condição, supostamente condutivel ao desenvolvimento microbiologico, merece destaque. Isto sugere que a dormência possa proteger as sementes de seus próprios processos degradativos e que, a completa embebicão, possa dificultar o ataque de microrganismos, possivelmente, através da anoxia ou de mecanismos de resistência, como a sintese de fitoalexinas (HALLOIN, 1983).

o controle da atividade biológica nas 


\section{MATERIAL E METODOS}

- presente trabalho foi conduzido no Laboratório de Análise de Sementes do Departamento de Agricultura da Escola Superior de Agricultura "Luiz de Queiroz" (ESALQ/USP), em Piracicaba/SP, e nos laboratórios de Fitopatologia, Fisiologia Vegetal e de Análise de

Sementes do Instituto Agronômico do Paraná (IAPAR), Londrina/PR, durante o período de junho de 1991 a novembro de 1992 .

\subsection{Escolha e Caracterização das sementes}

$$
\text { A escolna do trigo (Triticum aestivum L.), }
$$

como espécie a ser utilizada neste estudo, fundamentou-se nas situações análogas observadas, com as sementes desta cultura no campo, em função das oscilações de umidade, a que estão sujeitas.

Diante da possibilidade de ocorrerem diferenças de resposta aos tratamentos, devidas ao genótipo, foram empregados dois cultivares que apresentavam, entre si, diferenças tanto no aspécto genealógico, quanto nas suas características de porte e ciclo. Assim, foram utilizadas sementes dos cultivares 
OCEPAR 7- Batuira, criado no Centro Internacional de Melhoramento de Milho e Trigo, que apresenta genes para o nanismo (internódios curtos) e precocidade, e CEP 14 Tapes, criado pela Federação das Cooperativas de Trigo e Soja do Rio Grande do Sul, classificado como sendo de porte intermediário e de ciclo tardio (IAPAR, 1991).

Com o propósito de isolar os efeitos da condição fisiológica inicial, as sementes, obtidas junto ao IAPAR, provieram de lotes colnidos na safra de 1990 que, com base em análises preliminares de germinação e de vigor (testes de primeira contagem e de condutividade elétrica), apresentavam-se semelhantes quanto à qualidade fisiológica (Tabela 1).

Tabela 1. Caracteristicas iniciais dos lotes de sementes de trigo dos cultivares OCEPAR 7 - Batuira e CEP 14 - Tapes.

\begin{tabular}{|c|c|c|}
\hline \multirow[t]{2}{*}{ AVALI AÇÕES } & \multicolumn{2}{|c|}{ CULTIVARES } \\
\hline & Batuira & Tapes \\
\hline Germinação（\%） & 82,00 & 82,00 \\
\hline Primeira contagem de germinação (\%) & 72,00 & 68,00 \\
\hline Condutividade elétrica (Umhos/cm/g) & 24,15 & 24,18 \\
\hline Umidade (\%) & 12.30 & 12.80 \\
\hline
\end{tabular}

No sentido de evitar os possiveis efeitos do tamanho das sementes, cuja variabilidade pode 
interferir no seu desempenho (KALAKANNAVAR et al., 1989; PETERSON, et a 1., 1989), as amostras foram, previamente, padronizadas quanto a este aspecto, através do uso de peneiras de crivos oblongos e circulares. Foram ut ilizadas as sementes que, após serem retidas entre os crivos oblongos de $6 \frac{1}{2} / 64 \times 3 / 4$ e $9 / 64 \times 3 / 4$ de polegada, for $a m$ novamente retidas entre os crivos circulares de $10 \frac{1}{2} / 64$ e $7 \frac{1}{2} / 64$ polegada. Além disso, foram elimimadas as sementes que apresentavam qualquer sinal visivel de germinação. o material, assim selecionado, foi armazenado em câmara seca com umidade relativa do ar em torno de 45 a $50 \%$, até o inicio dos trabalhos.

\subsection{Obtenção e caracterização dos tratamentos}

Os tratamentos consistiram em submeter as sementes a periodos crescentes de hidratação, distanciados de 3 horas entre si, em rolos de papel toalha umedecidos na razão de 2,5 vezes o peso do papel seco e mantidos em germinador à temperatura constante de $20{ }^{\circ} \mathrm{C}$. O substrato (rolo de papel) foi formado por duas folhas de papel toalha de base e duas de cobertura, entre as quais, foram ditribuidas 100 sementes. O conteúdo de água, aplicado no substrato, foi o indicado para evitar problemas de excesso ou de déficit hídrico (PHANEENDRANATH, 1980; MARCOS FILHO et $\mathrm{a} 1 ., 1987$ ).

A variação de 3 horas, entre cada período 
de hidratação, foi definida em testes preliminares e teve, como critérios de escolha, a amplitude de acréscimo do teor de água das sementes, entre os periodos, e a repetitividade desse resultado.

o período máximo de hidratação considerado (48 horas) foi definido, considerando o momento em que a emissão radicular ocorria em taxa superior a $50 \%$ da população e o conteúdo de umidade requerido para a germinacão da espécie (GUSTA \& CHEN, 1987).

Imediat amente após o término de cada período de embebição, foram tomadas, ao acaso, amostras representativas para a determinação do conteúdo de água e para a caracterização visual dos tratamentos. As sementes remanescentes, de cada tratamento, foram retiradas dos substratos e submetidas à secagem em estufa com ar circulante, regulada à temperatura de $30{ }^{\circ} \mathrm{C}$, durante um periodo aproximado de 24 horas, ou até retornarem à umidade próxima da original ( $12,5 \%)$. Foram constituidas duas testemunhas que não passaram por hidratação; uma delas, contudo, permaneceu, durante 24 horas, no ambiente de secagem a que os demais tratamentos foram submetidos. Em seguida, as amostras dos tratamentos e das testemunhas foram colocadas em sacos plásticos lacrados e armazenadas no em câmara fria, com temperatura controlada de $10^{\circ} \mathrm{C}$, por um periodo aproximado de 2 meses que antecedeu a realização dos testes laboratoriais. 
A caracterização do material obtido, nos diversos tratamentos, foi realizada, imediatamente após o término de cada período de hidratação, baseando-se no teor de água e na estimativa da distribuição percentual de individuos que, na amostra, apresentavam características visiveis de desenvolvimento, previamente estabelecidas.

o teor de água das sementes foi determinado, em duas repetições de 50 sementes inteiras, por tratamento, empregando-se estufa regulada a 1053 ${ }^{\circ} \mathrm{C}$, de acordo com a metodologia descrita nas Regras para Análise de Sementes (BRASIL, 1980).

A caracterização visual das amostras com relação ao desenvolvimento das sementes individuais foi realizada em duas amostras de 100 sementes, por tratamento de hidratação, considerando a porcentagem de ocorrência dos individuos, cujas características de desenvolvimento, distinguíveis com o auxílio de lupa (aumento de 10 vezes), encontravam-se dentro de estádios do processo de germinação, préviamente estabelecidos.

As características de desenvolvimento, foram agrupadas em seis categorias, considerando o intumescimento, a ruptura do pericarpo, a exposição da plântula, a emissão radicular e o crescimento da raiz primária, de acordo com a sequência de eventos descrita para o gênero Triticum (HAYWARD, 1953).

Para maior detalhe da caracterização, 
alguns estádios do foram subdivididos, conforme mostra a Figura 1. o primeiro estádio de desenvolvimento, referente à fase não visivel do processo de germinação e identificado com a letra $A$, foi subdividido em $A_{1}$ (cariópses úmidas, com a supeficie do pericarpo, na região do embrião, ainda enrugada) e $A_{2}$ (semente hidratada, com a superficie do pericarpo distendida). O segundo estádio, ou $B$, envolveu a ruptura do pericarpo e a exposição do eixo embrionário, sendo subdividido em $\mathbf{B}_{\mathbf{1}}$ (com o pericarpo, na região do eixo embrionário, rompido e a emergência parcial da coleorriza) e $B_{2}$ (sementes com exposição completa do eixo embrionário e a coleorriza totalmente protuída). 0 terceiro estágio ( C ) representou a emissão da raíz primária, sendo subdividido em $\mathbf{C}_{1}$ (comprimento da raíz primária inferior a $1 \mathrm{~mm}$.) e $\mathbf{C}_{2}$ (raiz primária entre 1 e $3 \mathrm{~mm}$. de comprimento). Os estádios seguintes referem-se ao crescimento da raíz primária, sendo o quarto estádio ou $D$, representado pelas sementes com a raíz primária entre 3 e $5 \mathrm{~mm}$ de comprimento. O quinto estádio ( $E$ ) correspondeu às sementes com raizes primárias entre 5 e $10 \mathrm{~mm}$. e o par superior de raizes seminais em inicio de crescimento. 0 último estádio considerado ( $F$ ) reuniu os individuos cuja a raíz primária tinha o comprimento superior a $10 \mathrm{~mm}$, o primeiro par de raizes seminais entre 1 e $5 \mathrm{~mm}$. e o crescimento visivel do epicótilo. 


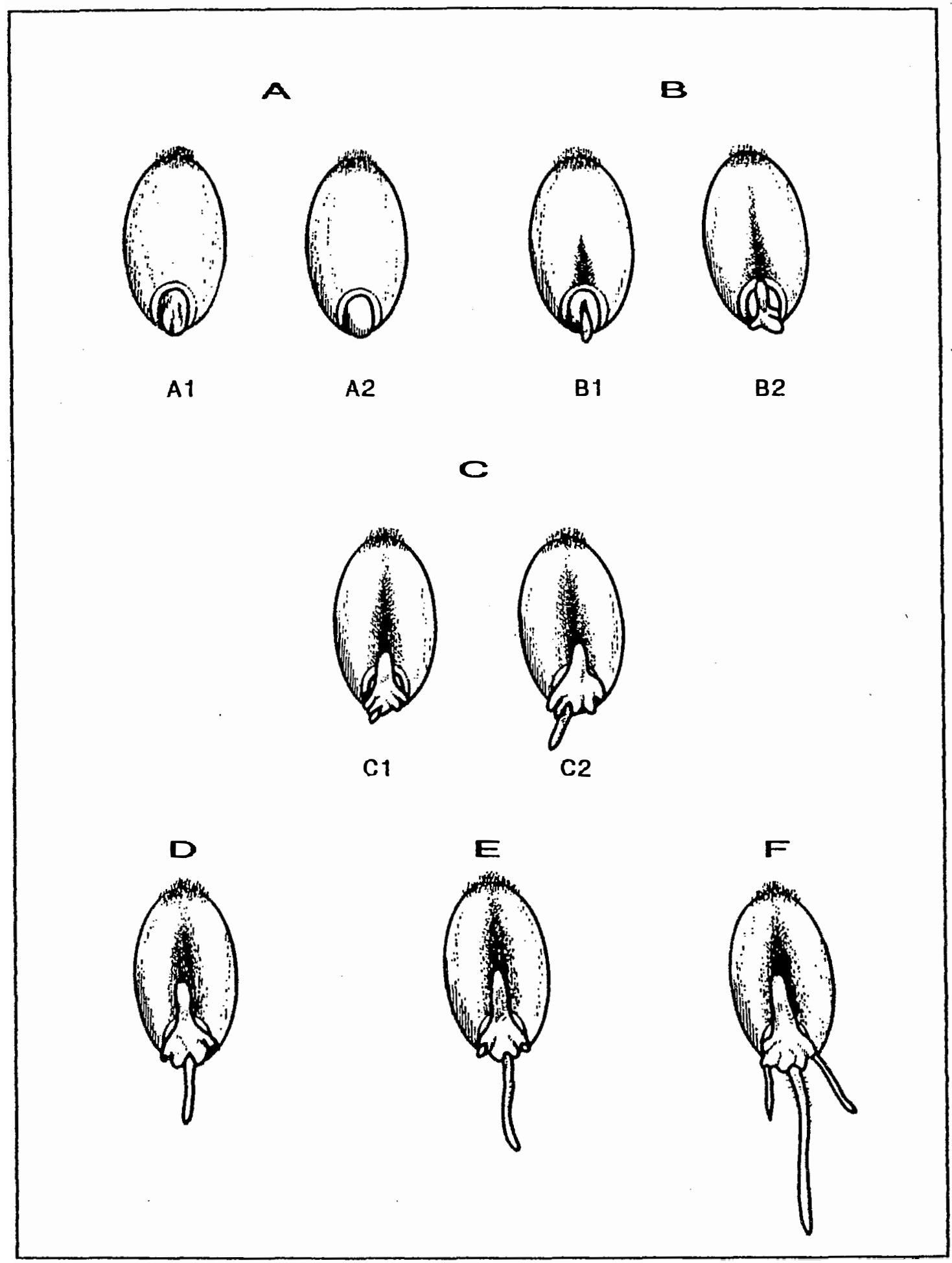

Figura 1. Esquemas das sementes representantes dos estádios de desenvolvimento considerados na caracterização dos tratamentos. 
3.3. Avaliação dos efeitos dos tratamentos

A avaliação dos tratamentos foi dividida em dois estudos. 0 estudo 1 ocupou-se das avaliações do desempenho fisiológico e da sanidade, em amostras de sementes, dos dois cultivares, submetidas aos diferentes tratamentos de hidratação; neste caso, foi considerada, a população total referente a cada um dos tratamentos. o Estudo 2, conduzido apenas com o cultivar OCEPAR 7 Batuira, avaliou o desempenho fisiológico de populações formadas, exclusivamente, por sementes que, fixados os periodos de hidratação, foram agrupadas segundo o estádio de desenvolvimento.

3.3.1. Estudo 1. Avaliação dos efeitos de periodos crescentes de hidratação variáveis de 0 a 48 horas na qualidade fisiológica e da sanidade de sementes de trigo

Neste estudo, realizado com as sementes dos cultivares OCEPAR 7 - Batuira e CEP 14 - Tapes, as avaliações do desempenho fisiológico foram efetuadas em 17 tratamentos, correspondendo aos periodos de hidratação e à testemunha não hidratada e submetida ao ambiente de secagem (HOS). Com o objetivo de verificar a ocorrência de efeitos das condições de secagem sobre os microrganismos, na avaliação da sanidade das sementes, além da testemunha HOs, avaliou-se a testemunha não hidratada e não submetida as condições de secagem ( $\mathrm{HO}$ ), conforme mostra a Tabela 2. 
Tabela 2. Denominação dos tratamentos e respectivos periodos de hidratação precedentes à secagem.

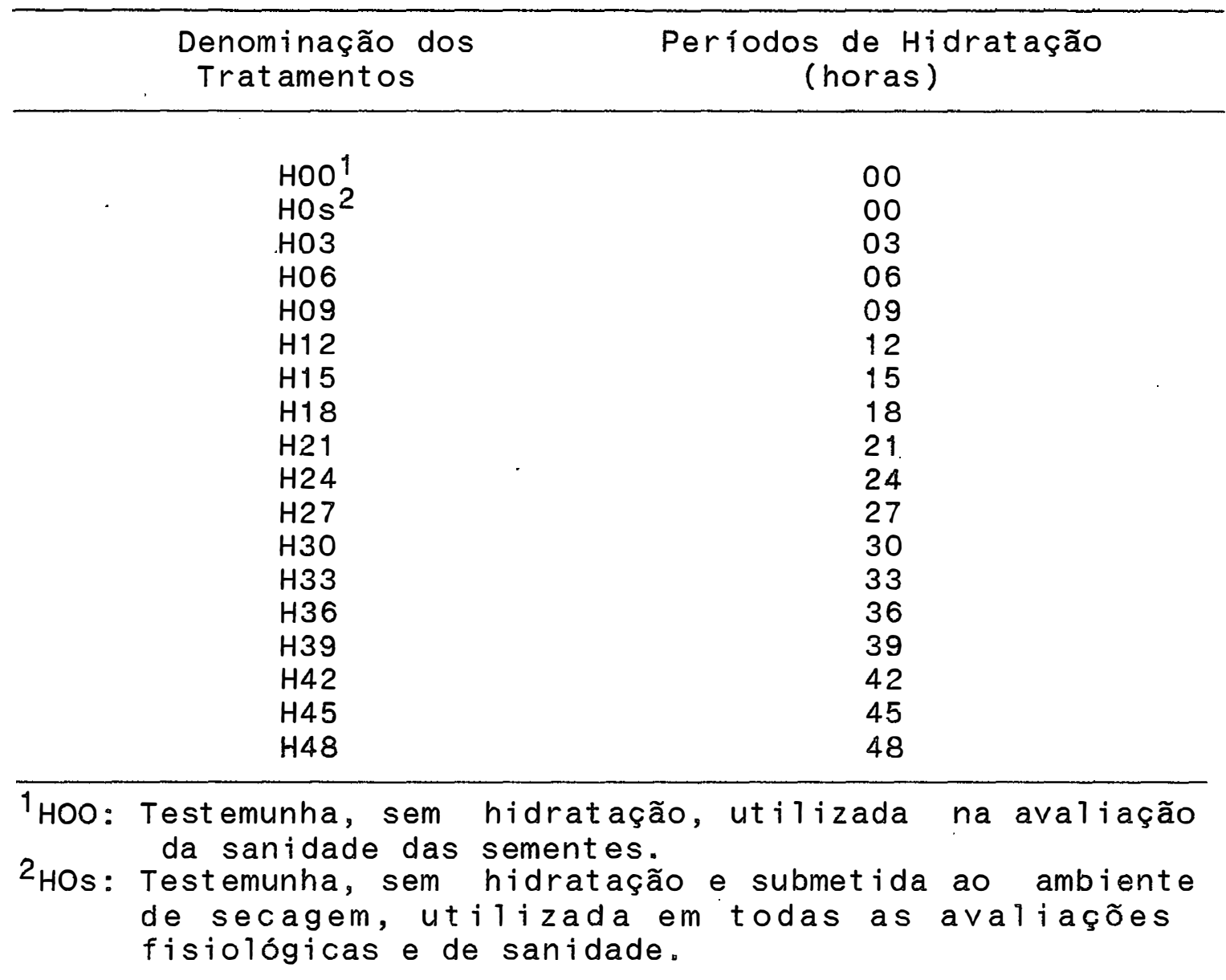

3.3.1.1. Avaliação do desempenho fisiológico

As avaliações, iniciadas dois meses após a obtenção dos tratamentos, foram conduzidas em testes de laboratório de viabilidade e de vigor de sementes, realizados em seis repetições referentes ao delineamento experimental. A viabilidade das sementes foi avaliada através dos testes de germinação e de emergência em areia, e o vigor, através dos testes de primeira contagem de germinação, de velocidade de emergência, de 
comprimento de plântula, do peso de matéria seca de plântula e de condutividade elétrica do meio de embebição.

A inclusão do teste de emergência em areia na avaliação da viabilidade das sementes, objetivou verificar a capacidade dos coleoptilos romperem a camada de $2 \mathrm{~cm}$ de areia, principalmente considerando as sementes em estádios mais avançados de desenvolvimento ( $E$ e F).

A uniformidade e a velocidade de germinação foram estimadas pelos testes de primeira contagem e de velocidade de emergência; o crescimento das plântulas resultantes foi avaliado, pelas determinações do comprimento e do peso de matéria seca, sendo considerada qualquer manifestação de crescimento das plântulas, normais ou anormais, procurando, com isso, evitar superestimativas do desempenho de tratamentos que tivessem permitido o crescimento de poucas plântulas normais, porém bem desenvolvidas; finalmente, a permeabilidade das membranas celulares foi indiretamente estimada através da determinação da condutividade elétrica do meio de embebição das sementes.

\section{Teste de germinacão}

Foi realizado em quatro amostras de 25 sementes por repetição. As sementes foram distribuidas em substrato de papel-toalha, umedecido com água destilada na razão de 2,5 vezes o peso do substrato seco; o 
conjunto foi levado para germinador regulado à temperatura constante de $20^{\circ} \mathrm{C}$. Efetuou-se avaliações no 4 으 e no $8 \underline{0}$ dias após a semeadura, de acordo com os critérios estabelecidos pelas Regras para Análise de Sementes (BRASIL, 1980). o resultado, expresso em porcentagem, foi obtido através do somatório do número de plântulas normais -nas duas contagens.

Teste de Emergência em areia

Foram semeadas duas amostras de 50 sementes, por repetição, em caixas plásticas contendo areia lavada umedecida na razão de 70 \% de sua capacidade de retenção de água. As sementes foram distribuidas, sobre uma camada do substrato com $6 \mathrm{~cm}$ de espessura e recobertas por outra com $2 \mathrm{~cm}$ (MARCOS FILHO et a1.,1987). O conjunto foi mantido em condições ambientais e o resultado, foi obtido em porcentagem plântulas emersas ao final de um período de 8 dias a partir da semeadura.

\section{Primeira contagem da germinação}

Foi realizado em conjunto com o teste de germinação, considerando a porcentagem de plântulas que, no 4 o dia após a instal ação do teste, presentavam as caracteristicas de normalidade descritas nas Regras para Análise de sementes (BRASIL, 1980) e o comprimento mínimo de $5 \mathrm{~cm}$. 
fndice de velocidade de emergência

A velocidade de emergência foi determinada em conjunto com o teste de emergência em areia. O índice foi obtido, a partir da contagem diária das plântulas emersas e usando-se a equacão indicada por MAGUIRE (1962):

$$
I . V . E .=G 1 / d 1+G 2 / d 2+\cdots+G+G / d n \text {, onde: }
$$

$G=$ número de plâtulas emersas em cada dia de contagem.

d = número de dias decorridos da semeadura até a contagem considerada.

\section{Avaliação do Comprimento das plântulas}

Foram utilizadas quatro amostras de 25 sementes por repetição. O procedimento básico para a instalacão do teste foi similar ao do teste de germinação, considerando algumas das especificações propostas pelo Comitê de Vigor da AOSA (1983).

As sementes foram distribuidas sobre uma linha traçada no papel-toalha de base, com o eixo embrionário perpendicularmente posicionado e com a radícula apontando para baixo. Os rolos colocados no interior de sacos plásticos, foram levados a um germinador, regulado à temperatura de $20^{\circ} \mathrm{C}$, por 7 dias em ausência de luz. Ao final desse período, foram marcados, no papel-toalha da base, os comprimentos do epicótilo e da raiz mais longa de cada plântula para medição posterior. Considerou-se, nesta avaliação, qualquer manifestação de 
crescimento do embrião, tanto de plântulas normais quanto de anormais; o somatório das medidas de comprimento foi dividido pelo número de indivíduos avaliados. o resultado foi expresso em cm/plântula.

\section{Peso de matéria seca das plântulas}

Para esta avaliação foram utilizadas as plântulas normais e anormais obtidas no teste de comprimento que, após serem destacadas dos resíduos dé cariópses, foram levadas para secar em estufa, regulada à temperatura de $70^{\circ} \mathrm{C}$, por 48 horas. o peso da matéria seca, de cada amostra, foi dividido pelo número de individuos que a compunham; o resultado foi expresso em mg/plântula.

\section{Determinacão da condutividade elétrica do} meio de embebição das sementes

Foi determinada através do método de condutividade de massa, indicado pelo Comitê de Vigor da AOSA (1983), em cluatro amostras de 25 sementes por repetiçấo estatística. Após a pesagem de cada amostra, as sementes foram colocadas em copos padronizados contendo 75 ml de água deionizada e, a seguir, levadas a uma câmara, regulada à temperatura de $20^{\circ} \mathrm{C}$, durante 24 horas. Ao final deste período, foi determinada a condutividade elétrica da solução através de um condutivímetro. Os resultados foram expressos em Umhos/cm/g? de sementes. 


\section{Procedimento estatistico}

Os dados foram analisados, no sistema de Análise Estatistica para Microcomputadores - SANEST (ZONTA et al., 1984), isoladamente para cada cultivar e parâmetro estudado (testes de viabilidade e vigor), em delineamento experimental inteiramente casualizado, com 17 tratamentos (16 periodos de hidratação e a testemunha, Hos) e seis repeticões. Para a análise de variância, os dados em porcentagem obtidos nos testes de germinação, emergencia em areia e primeira contagem, sofreram a transformação arc sen $\sqrt{ } \% / 100$. As médias foram comparadas pelo teste de Tukey, ao nivel de 5\% de probabilidade, sendo o comportamento da variação das médias, em função dos periodos de hidratação, representados, analiticamente, pelas equações de regressão melhor ajustadas e, graficamente, através de diagramas de dispersão e curvas de regressão correpondentes.

\subsubsection{Avaliação da sanidade das sementes}

Foi realizada utilizando-se do método de papel de filtro com congelamento, geralmente empregado para a deteç̧ão de fungos em sementes (NEERGARD, 1979). Foram utilizadas, nesta avaliação, quatro amostras de 50 sementes de cada tratamentos e das duas testemunhas ( $H O$ e HOs). Distribuidas em placas de Petri contendo três folhas de papel de filtro, umedecidas com água destilada, as 
sementes foram incubadas, à temperatura de $20^{\circ} \mathrm{C}$ por 24 horas, com 12 horas sob 1 uz fluorescente e 12 horas em ausência de luz. Em seguida, foram submetidas ao congelamento à temperatura aproximada de $-18^{\circ} \mathrm{C}$, por 24 horas, retornando à incubação por mais 5 dias. Após este periodo, foram realizadas as observacões nas amostras, com o auxilio de estereomicroscópio e microscópio composto, para as determinações da frequência e identidade dos fungos que se desenvolveram (NASSER, 1987; MENTEN, 1988). os resultados (médias das 4 repetições), expressos em porcentagem, não foram submetidos à análise estatistica. As principais espécies de fungos (quanto à ocorrência ou importância para a cultura) detectadas nas sementes, foram reunidas em dois grupos; o primeiro, representou as espécies originárias de infecção no campo e, o segundo, os fungos especificos de armazenamento. o somatório das médias observadas, nas frequências dos fungos de campo e de armazenamento, e a porcentagem de sementes isentas de fungos foram apresentadas, graficamente, através de diagramas de dispersão. 
3.3.2. Estudo 2: Caracterização e avaliação da qualidade fisiológica de sementes de trigo (cV. OCEPAR 7 Batuira), reunidas em grupos, de acordo com estádios de desenvolvimento germinativo atingidos, nas amostras submetidas a periodos crescentes de hidratação.

Este estudo, realizado exclusivamente com o cultivar OCEPAR 7 - Batuira, constou da avaliação do desempenho de populações de sementes que, nas amostras de um determinado periodo de hidratação, encontravam-se dentro de certos limites de desenvolvimento.

3.3.2.1. Caracterização dos grupos de desenvolvimento

Foram estabelecidos quatro grupos de desenvolvimento envolvendo etapas especificas do processo de germinação de sementes que, por sua vez, eram representadas por um ou mais dos estádios referidos na Figura 1, conforme mostra a Figura 3.

$$
\text { Efetuou-se as determinações da }
$$

porcentagem de ocorrência e do conteúdo de água das sementes representantes de cada grupo de desenvolvimento, ambas em duas sub-amostras de 50 sementes, retiradas das amostras imediatamente após cada periodo de hidratação. 
Tabela 3. Estudo 2. Caracterização dos agrupamentos de sementes estabelecidos, em relação às etapas do processo de germinação envolvidas e aos estádios de desenvolvimento reunidos

\begin{tabular}{clc}
\hline Grupos & \multicolumn{1}{c}{ Caracterização } & $\begin{array}{r}\text { Estádios } \\
\text { reunidos }\end{array}$ \\
\hline I & Sementes Embebidas & $\mathrm{A}\left(\mathrm{A}_{1}+\mathrm{A}_{2}\right)$ \\
I I & Emergência da Coleorriza & $\mathrm{B}\left(\mathrm{B}_{1}+\mathrm{B}_{2}\right)$ \\
II I & Emissão Radicular & $\mathrm{C}\left(\mathrm{C}_{1}+\mathrm{C}_{2}\right)$ \\
IV & Crescimento Radicular & $\mathrm{D}+\mathrm{E}+\mathrm{F}$ \\
\hline
\end{tabular}

1: Estádios caracterizados na Figura 1.

Os grupos estabelecidos não ocorreram em todos os periodos de hidratação e, em alguns casos o fizeram em niveis muito reduzidos. Dessa forma, a Tabela 4 apresenta os periodos de hidratação em que foi possivel obter, em quantidade adequada para os testes, sementes representantes dos grupos de desenvolvimento.

Tabela 4. Estudo 2. Relação dos periodos de hidratação em que foram obtidas as sementes representantes de cada grupo de desenvolvimento
Periodos de Hidratação Grupos de Desenvolvimento (horas)
03 a 12
I
15 a 27
I e I I
30 a 33
I, I I e I I
36 a 48
I, II, III $e$ IV 
3.3.2.3. Avaliação da qualidade fisiológica

Foram empregados os testes de germinação, de emergência em areia, do indice de velocidade de emergência, de comprimento de plântulas e de condutividade elétrica do meio de embebição. Cada teste foi realizado em quatro amostras de 10 individuos, por repetição, de cada grupo de desenvolvimento, empregando-se procedimentos similares aos adotados no Estudo 1.

3.3.2.4. Estudo 2. Procedimento estatistico

A análise estatistica dos dados foi

realizada, isoladamente para cada periodo de hidratação, em delineamento inteiramente casualizado com seis repetições. Neste caso foram efetuadas análises comparativas dos resultados obtidos pelos grupos e pela amostra total do período considerado. Além disso, foram feitas análises comparativas entre os dados obtidos por sementes de um mesmo grupo de desenvolvimento, porém oriundas de períodos de hidratação diferentes. Neste caso, a variação das médias em função do período de hidratação foi representada, analiticamente, através de equações de regressão e, graficamente, pelos diagramas de dispersão das médias estimadas. 


\section{RESULTADOS E DISCUSSÃO}

Apesar da extensa literatura existente sobre os efeitos da hidratação e secagem no comportamento de sementes, poucos têm sido os trabalhos que relacionam os resultados às características do cultivar, ao lote empregado, ou mesmo, às respostas das individuais das sementes de um único lote. Diante disso, visando identificar as reações da população de sementes, aos tratamentos de hidratação, em função do cultivar e da condição fisiológica das sementes individuais, procurou-se caracterizar os tratamentos com base na evolução do desenvolvimento dos individuos que compunham as amostras e no nivel de hidratação atingido.

4.1. Caracterização dos tratamentos de hidratação com base na porcentagem de ocorrência de estádios visiveis de desenvolvimento germinativo e no teor de água das amostras de sementes

A caracterização das amostras de sementes após terem sido submetidas aos vários periodos de hidratação, acha-se apresentada nas tabelas 5 e 6 . 
Tabela 5. Teor de água e distribuição da ocorrência (\%) de individuos, apresentando diferentes estádios de desenvolvimento germinativo, nas amostras de sementes de trigo, cultivar OCEPAR 7 - Batuira, submetidas a periodos variáveis de hidratação.

\begin{tabular}{|c|c|c|c|c|c|c|c|c|c|c|}
\hline \multirow{3}{*}{$\begin{array}{l}\text { Períodos } \\
\text { de } \\
\text { Hidratação } \\
\text { (horas) }\end{array}$} & \multirow{3}{*}{$\begin{array}{c}\text { Teor } \\
\text { de } \\
\mathrm{H}_{2} \mathrm{O} \\
(\%)\end{array}$} & \multicolumn{9}{|c|}{ Distribuição (\%) dos estádios de desenvolvimento } \\
\hline & & \multicolumn{2}{|c|}{ A } & \multicolumn{2}{|c|}{ B } & \multicolumn{2}{|c|}{ C } & \multirow[t]{2}{*}{ D } & \multirow[t]{2}{*}{ E } & \multirow[t]{2}{*}{$\mathrm{F}$} \\
\hline & & $A_{1}$ & $A_{2}$ & $B_{1}$ & $B_{2}$ & $C_{1}$ & $\mathrm{C}_{2}$ & & & \\
\hline $00(*)$ & 11.14 & 0 & 0 & 0 & 0 & 0 & 0 & 0 & 0 & 0 \\
\hline Os $(* *)$ & 12,02 & 0 & 0 & 0 & 0 & 0 & 0 & 0 & 0 & 0 \\
\hline 03 & 21,95 & 97 & 3 & 0 & 0 & 0 & 0 & 0 & 0 & 0 \\
\hline 06 & 26.10 & 95 & 5 & 0 & 0 & 0 & 0 & 0 & 0 & 0 \\
\hline 09 & 28,85 & 84 & 16 & 0 & 0 & 0 & 0 & 0 & 0 & 0 \\
\hline 12 & 33,02 & 65 & 30 & 5 & 0 & 0 & 0 & 0 & 0 & 0 \\
\hline 15 & 35,51 & 25 & 63 & 10 & 2 & 0 & 0 & 0 & 0 & 0 \\
\hline 18 & 37,02 & 8 & 72 & 14 & 6 & 0 & 0 & 0 & 0 & 0 \\
\hline 21 & 37.68 & 2 & 60 & 24 & 14 & 0 & 0 & 0 & 0 & 0 \\
\hline 24 & 39,90 & 0 & 45 & 30 & 25 & 0 & 0 & 0 & 0 & 0 \\
\hline 27 & 41,24 & 0 & 27 & 35 & 37 & 1 & 0 & 0 & 0 & 0 \\
\hline 30 & 42,08 & 0 & 17 & 28 & 53 & 2 & 0 & 0 & 0 & 0 \\
\hline 33 & 43,44 & 0 & 11 & 23 & 60 & 4 & 2 & 0 & 0 & 0 \\
\hline 36 & 44,08 & 0 & 8 & 15 & 56 & 10 & 7 & 3 & 1 & 0 \\
\hline 39 & 46,21 & 0 & 6 & 10 & 39 & 15 & 20 & 6 & 4 & 0 \\
\hline 42 & 47,41 & 0 & 5 & 3 & 35 & 6 & 30 & 10 & 10 & 1 \\
\hline 45 & 49,99 & 0 & 5 & 4 & 24 & 3 & 20 & 22 & 20 & 2 \\
\hline 48 & 51,56 & 0 & 5 & 4 & 13 & 2 & 18 & 24 & 29 & 5 \\
\hline
\end{tabular}


Tabela 6. Teor de água e distribuição da ocorrência (\%) de individuos, apresentando diferentes estádios de desenvolvimento germinativo, nas amostras de sementes de trigo, cultivar CEP 14 - Tapes, submetidas aos vários periodos de hidratação.

\begin{tabular}{|c|c|c|c|c|c|c|c|c|c|c|}
\hline \multirow{3}{*}{$\begin{array}{l}\text { Períodos } \\
\text { de } \\
\text { Hidratação } \\
\text { (horas) }\end{array}$} & \multirow{3}{*}{$\begin{array}{c}\text { Teor } \\
\text { de } \\
\mathrm{H}_{2} \mathrm{O} \\
(\%) \\
\end{array}$} & \multicolumn{9}{|c|}{ Distribuição (\%) dos estádios de desenvolvimento } \\
\hline & & \multicolumn{2}{|c|}{ A } & \multicolumn{2}{|c|}{ B } & \multicolumn{2}{|c|}{ C } & \multirow[t]{2}{*}{ D } & \multirow[t]{2}{*}{$E$} & \multirow[t]{2}{*}{$F$} \\
\hline & & $A_{1}$ & $\mathrm{~A}_{2}$ & $\mathrm{~B}_{1}$ & $\mathrm{~B}_{2}$ & $C_{1}$ & $\mathrm{C}_{2}$ & & & \\
\hline $00(*)$ & 11.50 & 0 & 0 & 0 & 0 & 0 & 0 & 0 & 0 & 0 \\
\hline Os $(* *)$ & 12,34 & 0 & 0 & 0 & 0 & 0 & 0 & 0 & 0 & 0 \\
\hline 03 & 21,14 & 99 & 1 & 0 & 0 & 0 & 0 & 0 & 0 & 0 \\
\hline 06 & 25,72 & 98 & 2 & 0 & 0 & 0 & 0 & 0 & 0 & 0 \\
\hline 09 & 28,69 & 94 & 6 & 0 & 0 & 0 & 0 & 0 & 0 & 0 \\
\hline 12 & 32,25 & 92 & 5 & 3 & 0 & 0 & 0 & 0 & 0 & 0 \\
\hline 15 & 34,54 & 86 & 10 & 3 & 1 & 0 & 0 & 0 & 0 & 0 \\
\hline 18 & 36,17 & 65 & 30 & 3 & 2 & 0 & 0 & 0 & 0 & 0 \\
\hline 21 & 36.72 & 27 & 65 & 5 & 3 & 0 & 0 & 0 & 0 & 0 \\
\hline 24 & 39,19 & 14 & 71 & 11 & 4 & 0 & 0 & 0 & 0 & 0 \\
\hline 27 & 40,43 & 0 & 72 & 17 & 11 & 0 & 0 & 0 & 0 & 0 \\
\hline 30 & 41,96 & 0 & 53 & 14 & 32 & 1 & 0 & 0 & 0 & 0 \\
\hline 33 & 43,34 & 0 & 35 & 13 & 49 & 3 & 0 & 0 & 0 & 0 \\
\hline 36 & 43,89 & 0 & 34 & 8 & 46 & 10 & 2 & 0 & 0 & 0 \\
\hline 39 & 46,00 & 0 & 25 & 11 & 41 & 8 & 13 & 2 & 0 & 0 \\
\hline 42 & 47,06 & 0 & 26 & 7 & 28 & 7 & 23 & 6 & 3 & 0 \\
\hline 45 & 49,33 & 0 & 21 & 5 & 14 & 7 & 27 & 17 & 8 & 1 \\
\hline 48 & 50,46 & 0 & 17 & 4 & 9 & 6 & 20 & 24 & 18 & 2 \\
\hline
\end{tabular}




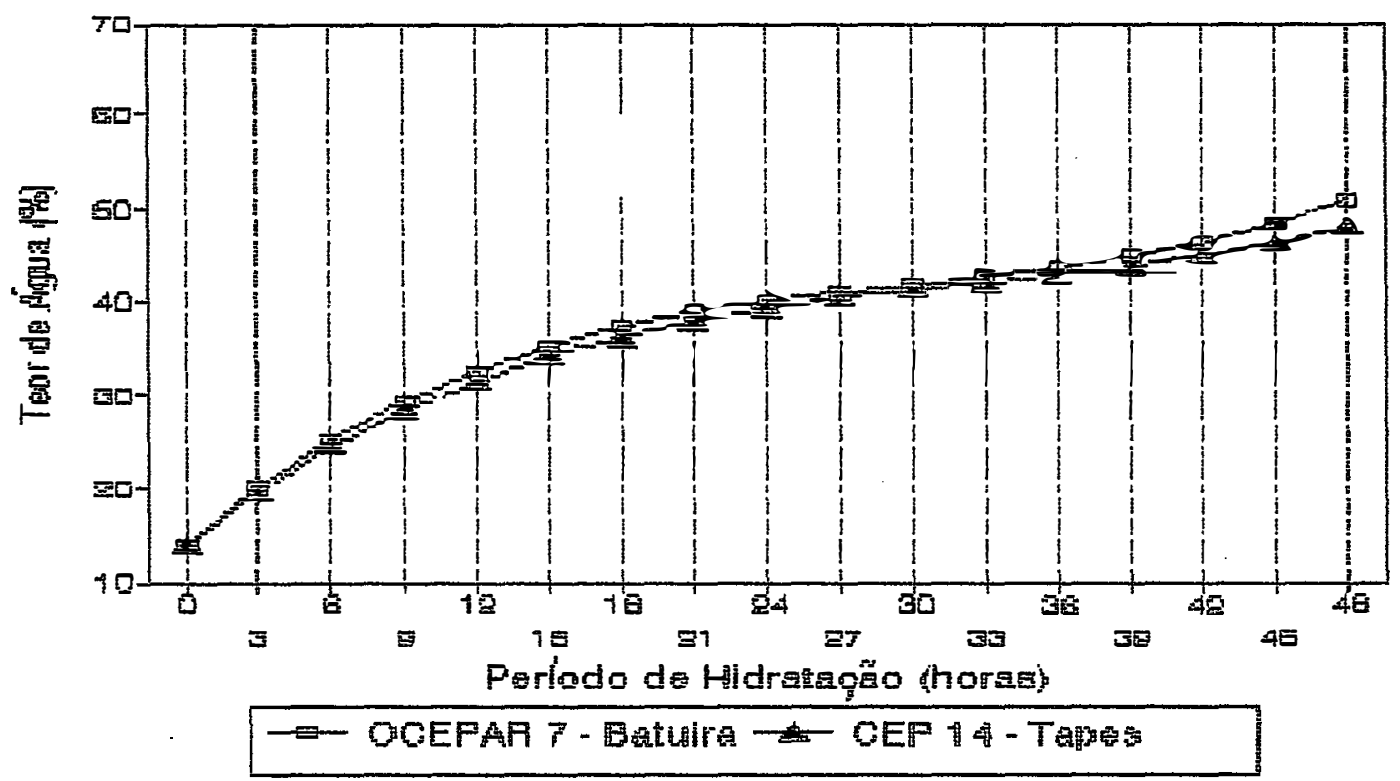

Figura 2. Marcha de absorção de água, em função do periodo de hidratação, das sementes de trigo dos cultivares OCEPAR 7 - Batuira e CEP 14 - Tapes.

Observando-se as tabelas 5 e 6 verifica-se que, apesar dos cultivares diferirem entre si nas caracteristicas de porte e de ciclo, o comportamento das amostras de sementes de ambos, no que diz respeito a evolução dos estádios de desenvolvimento com o avanço dos períodos de hidratação, foi semelhante. Contudo, ocorreram diferenças na velocidade de desenvolvimento embrionário; ou seja, no cultivar precoce (OCEPAR 7 - Batuira), a ruptura do tegumento e a emissão da coleorriza (nivel B), ocorreu em taxas mais elevadas do que as do cultivar mais tardio (CEP 14 - Tapes).

Apesar da diferença observada na evolução dos estádios de desenvovimento, em função do período de 
hidratação, as curvas de absorção de água, das sementes de ambos os cultivares, seguiram o mesmo padrão e apresentaram valores praticamente iguais.

A marcha de absorção de água (Fig. 2) mostra um padrão trifásico característico no qual, após uma fase inicial de rápida absorção de água (de 0 a 21 horas de hidratação), observa-se uma fase intermediária de absorção lenta (21 a 36 horas de hidratação) e, a seguir, uma nova elevação na velocidade de absorção, coincidindo com o aumento, na população, da proporção de sementes que apresentavam o crescimento radicular.

\subsection{Estudo 1}

4.2.1. Avaliação do desempenho fisiológico.

\section{Viabilidade das sementes}

Os dados obtidos nos testes de germinação e de emergência em areia (Tabela 7; Figuras 3 e 4), mostram que nenhum efeito favorável, significativo, ocorreu quando realizadas comparações entre os tratamentos e a testemunha. Esta ausência de efeitos pode ter ocorrido devido à alta qualidade inicial das sementes empregadas, conforme mostram os dados da Tabela 1. De acordo com alguns autores, os efeitos positivos dos tratamentos de hidratação/desidratação são mais evidentes em sementes com níveis de deterioração elevados (BASU, 1976; GOLDSWORTHY et a1.,1982; WARD \& POWELL, 1983), ou quando as sementes 
tratadas são submetidas a condições adversas ao desempenho (HENCKEL, 1964; BLEAK \& KELLER, 1970; BASU, 1976 ; BRADFORD, 1986; DEY (PATHAK) \& MUKHERJEE, 1988).

Outros autores, no entanto, não encontraram consistência, nas respostas das sementes submetidas a tratamentos de hidratação prévia (LUSH et al., 1981; TILDEN \& WEST, 1985; BLACK \& EI-HADI, 1992). Contudo, apesar de estatisticamente não significativos, os resultados principalmente os do cultivar OCEPAR 7 Batuíra, revelam uma tendência de decréscimo, quando as sementes são submetidas a periodos curtos de hidratação, com elevação posterior, até atingir um máximo nos períodos situados entre 21 e 27 horas. Este comportamento concorda com a observação de que os efeitos benéficos se evidenciam, apenas, quando a hidratação for realizada em periodos superiores a um determinado limite (BERRIE \& DRENAN, 1971); existem referências, no entanto, de que periodos breves ( 6 horas, por exemplo) são suficientes para melhorar a performance das sementes (HAIGH \& GRABE, 1972 ; HANSON, 1973; BASU, 1976; GOLDSWORTHY, et a 1.,1982).

Os dados mostram, genericamente, que as sementes, em ambos os cultivares, sofreram declínio no desempenho a partir do periodo em que houve a máxima resposta absoluta. Com relação ao teste de germinação, os dados mostram um comportamento semelhante para os dois cultivares. O teste de emergência em areia, para o 
cultivar OCEPAR 7 - Batuira, indicou um comportamento semelhante ao obtido no teste de germinação, ou seja, a secagem após hidratações de até 30 horas (sementes com $42 \%$ de água) não afetou o desempenho das sementes; para o cultivar CEP 14 - Tapes, entretanto, a secagem não afetou a resposta ao teste de emergência em areia, enquanto que, a germinação, deste cultivar, foi afetada quando a secagem foi promovida, a partir de 33 horas de hidratação (sementes apresentando teor de água superior a $43 \%$ ).

o periodo de hidratacão, a partir do qual as sementes tornaram-se gradativamente mais sensiveis à secagem (tratamento $\mathrm{H} 30$ ), coincidiu com o inicio da emissão da raíz primária (estádio C), nas populações de ambos os cultivares (Tabelas 5 e 6 ). Segundo vários autores, a emissão radicular seria o momento limite de tolerância à desidratação dentro do processo de germinação (MAY et a 1., 1962; HENCKEL, 1964; CHEN et a 1., 1968; SALIN \& TOOD, 1968; DELTOUR \& JAQMARD, 1974; HEGARTY, 1978; TONKIN, 1985; LABOURIAU, 1983; BEWLEY \& BLACK, 1985 ; BRADFORD, 1986). Contudo, comparando os dados obtidos nos testes de germinação e de emergência em areia (principalmente, o último com relação ao cultivar CEP 14 Tapes), com a evolução no desenvolvimento dos indivíduos no decorrer da hidratação (Tabelas 5 e 6), verifica-se que o decréscimo na viabilidade não correspondeu, proporcionalmente, ao aumento das sementes que, na 
população, que emitiram raízes primárias. As amostras de sementes do cultivar CEP 14 - Tapes submetidas ao período de hidratação de 48 horas, por exemplo, apresentaram $70 \%$ dos individuos com raizes primárias emitidas (somatório dos estádios C, D, E e F da Tabela 6) e alcançaram emergência em areia de $79,9 \%$ (Tabela 7); 0 fato indica que algumas sementes, apesar de se encontrarem em estádio considerado como sensivel, foram tolerantes à desidratação. Situação semelhante, em que a viabilidade das sementes se manteve, após a desidratação, mesmo quando realizada em estádios avançados da germinação, foi evidenciada por CARCELAR \& SORIANO (1972).

Outros autores (SEN \& OSBORNE, 1974;

HEGARTY, 1977b) evidenciaram que, plântulas que haviam emitido a raiz primária puderam ser desidratadas sem que a morte ocorresse; com a reidratação, no entanto, o crescimento radicular subsequente, foi retomado a partir de iniciações secundárias, fato igualmente observado no presente trabalho. A emissão radicular, portanto, parece não ser, por si só, um referencial adequado na definição do estádio de sensibilidade ou de tolerância à desidratação dentro do processo de germinação. 
Tabela 7. Estudo 1. Comparação entre as médias (\%) dos testes de germinação e de emergência em areia, para os efeitos de tratamentos de hidratação (variáveis de 0 a 48 horas), seguidos de secagem, em sementes de trigo dos cultivares OCEPAR 7 - Batuíra e CEP 14 - Tapes.

\begin{tabular}{|c|c|c|c|c|c|c|c|}
\hline & \multicolumn{4}{|c|}{$\underset{(\%)}{\operatorname{Germinação~}} 1$} & \multicolumn{3}{|c|}{$\begin{array}{c}\text { Emergência em areia } 1 \\
(\%)\end{array}$} \\
\hline rat amentos & \multicolumn{2}{|c|}{ Batuira } & \multicolumn{2}{|l|}{ Tapes } & Batuira & \multicolumn{2}{|l|}{ Tapes } \\
\hline HOS & 83.73 & $a$ & 78.04 & $a b c$ & $88.14 \mathrm{a}$ & 82.56 & $a b$ \\
\hline $\mathrm{HO3}$ & 82.02 & $a b$ & 78.42 & $a b c$ & $86.60 \mathrm{abc}$ & 82.07 & $a b$ \\
\hline HO6 & 84.20 & $a$ & 81.70 & $a b$ & $80.54 \mathrm{abcd}$ & 82.73 & $a b$ \\
\hline HO9 & 81.42 & $a b$ & 82.04 & $a b$ & $82.13 \mathrm{abc}$ & 83.13 & $a b$ \\
\hline $\mathrm{H} 12$ & 80.17 & $a b$ & 78.75 & $a b c$ & $83.78 \mathrm{abc}$ & 81.71 & $a b$ \\
\hline $\mathrm{H} 15$ & 82.59 & $a b$ & 84.88 & $a$ & $84.60 \mathrm{abc}$ & 83.69 & $a b$ \\
\hline H18 & 83.49 & $a$ & 82.58 & $a b$ & $85.87 a b c$ & 84.75 & $a$ \\
\hline $\mathrm{H} 21$ & 86.70 & $\mathrm{a}$ & 83.12 & $a b$ & $85.54 a b c$ & 83.64 & $a b$ \\
\hline $\mathrm{H} 24$ & 84.28 & $a$ & 79.10 & $a b c$ & $87.07 a b$ & 84.12 & $a$ \\
\hline $\mathrm{H} 27$ & 86.99 & $a$ & 82.15 & $a b$ & $89.35 \mathrm{a}$ & 83.02 & $a b$ \\
\hline H3O & 84.54 & $a$ & 76.64 & $b c d$ & $83.40 \mathrm{abc}$ & 81.66 & $a b$ \\
\hline H33 & 75.92 & $\mathrm{bc}$ & 70.38 & cde & 77.53 bcde & 81.60 & $a b$ \\
\hline H36 & 71.39 & $c d$ & 65.08 & ef & 77.44 bcoe & 80.63 & $a b$ \\
\hline H39 & 70.74 & $c d$ & 67.63 & de & $77.02 \mathrm{cde}$ & 81.39 & $a b$ \\
\hline $\mathrm{H} 42$ & 66.22 & de & 65.51 & ef & 70.48 def & 75.93 & $b$ \\
\hline $\mathrm{H} 45$ & 55.84 & $f$ & 57.53 & $f$ & $64.68 f$ & 75.61 & $b$ \\
\hline H48 & 60.36 & ef & 57.52 & $f$ & 66.79 ef & 79.90 & $a b$ \\
\hline CV \% & 4.21 & & 5.64 & & 5.69 & 4.39 & \\
\hline
\end{tabular}

1] Médias seguidas pela mesma letra na coluna não diferem, entre si, pelo Teste de Tukey (5\% de probabilidade). 


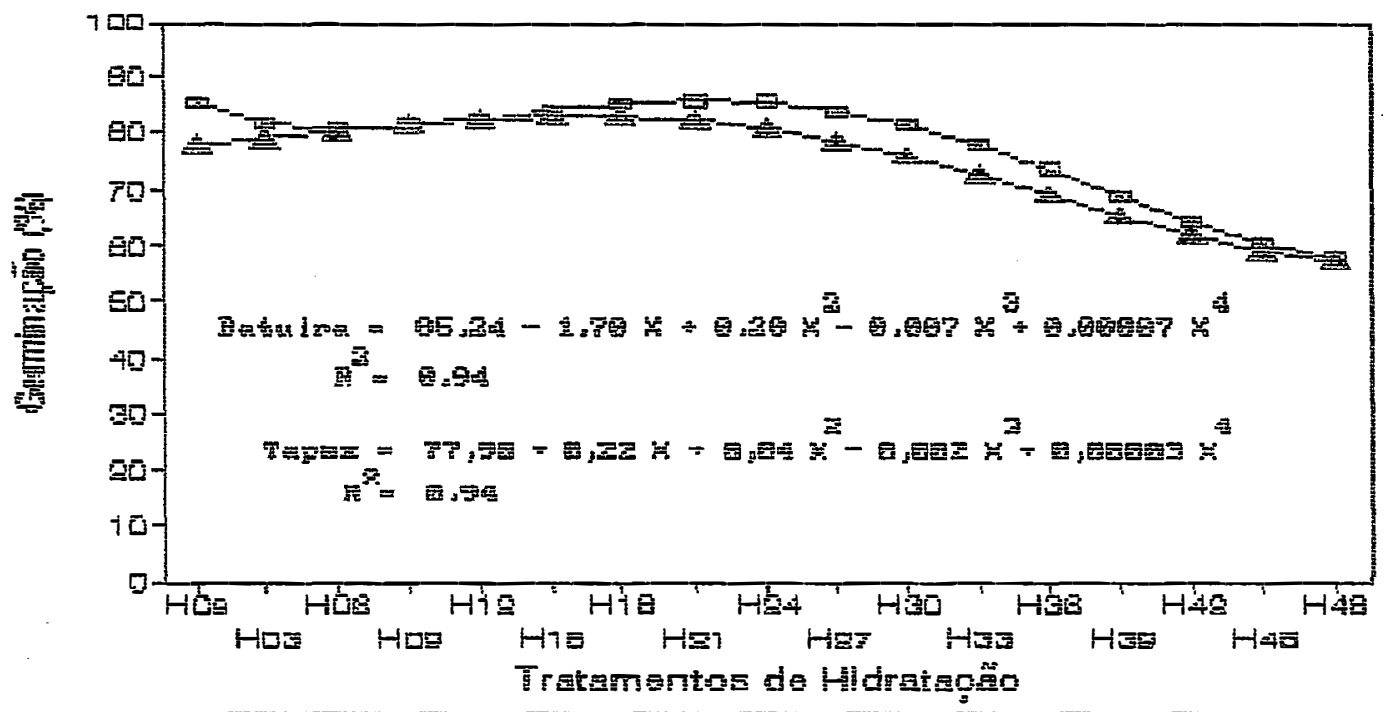

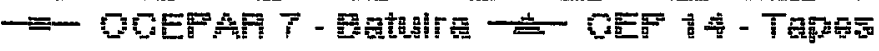

Figura 3.Estudo 1. Germinação: curvas de regressão polinomial para os efeitos dos tratamentos de hidratação e secagem em sementes de trigo dos cultivares OCEPAR 7 - Batuira e CEP 14 - Tapes.

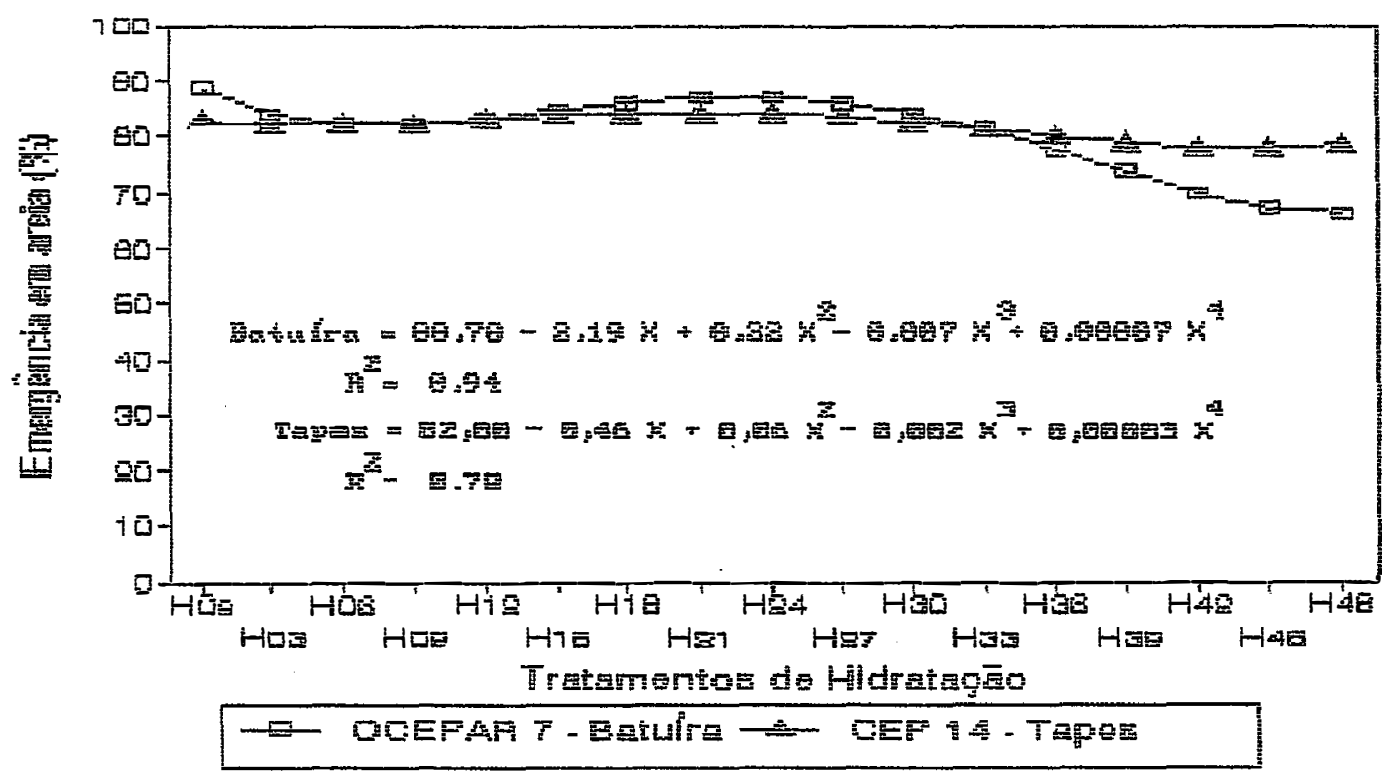

Figura 4. Estudo 1. Emergência em areia: curvas de regressão polinomial para os efeitos dos tratamentos de hidratação e secagem em sementes de trigo dos cultivres OCEPAR 7 - Batuíra e CEP 14 - Tapes. 


\section{Aceleração e sincronismo da germinação}

Estes aspectos foram avaliados através dos testes de primeira contagem de germinação e do teste de velocidade de emergência em areia.

Os resultados, destes testes, apresent ados

na Tabela 8 e nas Figuras 5 e 6 , mostram um comportamento semelhante ao apresentado pelos testes de viabilidade. A variação dos dados, obtidos no teste de primeira contagem, foi semelhante para os dois cultivares. Contudo, os resultados do cultivar CEP 14 - Tapes foram inferiores e, além disso, os tratamentos H18 e H27 superaram significativamente a testemunha (HOs) enquanto que, no cultivar OCEPAR 7 - Batuira, a testemunha não foi superada. A secagem das sementes submetidas às hidratações superiores a 30 horas, para o cultivar Batuira, e 36 horas, para o cultivar Tapes, trouxeram prejuizos com significado estatístico.

Os dados obtidos no teste de velocidade de emergência para o cultivar OCEPAR 7 - Batuira (Fig. 6), mostraram a mesma distribuição verificada no teste de primeira contagem. Contudo, no cultivar CEP 14 - Tapes houve uma tendência, não significativa, de elevação nos resultados, à medida em que foi ampliado o período de préhidratacão . 
Tabela 8. Estudo 1. Comparação entre as médias dos testes de primeira contagem de germinação (\%) e de velocidade de emergência em areia (indice), para os efeitos de tratamentos de hidratação (variáveis de 0 a 48 horas), seguidos de secagem, em sementes de trigo dos cultivares OCEPAR 7 - Batuira e CEP 14 - Tapes.

\begin{tabular}{|c|c|c|c|c|c|c|c|c|}
\hline \multirow[b]{2}{*}{ Tratamentos } & \multicolumn{4}{|c|}{$\begin{array}{c}\text { Primeira contagem } \\
(\%)\end{array}$} & \multicolumn{4}{|c|}{$\begin{array}{c}\text { Velocidade emergência }{ }^{1} \\
\text { (indice) }\end{array}$} \\
\hline & Batuir & & Tapes & & Batuir & & Tapes & \\
\hline HOS & 80.16 & a & 56.34 & $b c d$ & 26.09 & $a b c d$ & 22.42 & a \\
\hline HO3 & 78.03 & $a b$ & 59.56 & $a b c d$ & 24.01 & cde & 22.67 & a \\
\hline HO6 & 83.86 & $\mathrm{a}$ & 64.19 & $a b c$ & 23.42 & $\mathrm{cde}$ & 22.36 & a \\
\hline HO9 & 78.37 & $a b$ & 66.75 & $a b$ & 24.00 & cde & 22.83 & a \\
\hline $\mathrm{H} 12$ & 77.72 & $a b$ & 55.01 & $c d$ & 24.60 & bcde & 22.53 & a \\
\hline $\mathrm{H} 15$ & 79.12 & $a b$ & 64.37 & $a b c$ & 25.39 & $a b c d$ & 23.45 & a \\
\hline $\mathrm{H} 18$ & 79.39 & $a b$ & 68.07 & a & 27.11 & $a b c$ & 22.83 & a \\
\hline $\mathrm{H} 21$ & 82.84 & $a$ & 65.33 & $a b c$ & 26.43 & $a b c$ & 23.52 & a \\
\hline $\mathrm{H} 24$ & 79.66 & $a b$ & 65.51 & $a b c$ & 28.19 & $a b$ & 24.34 & a \\
\hline $\mathrm{H} 27$ & 83.78 & a & 68.60 & $a$ & 28.73 & a & 23.55 & a \\
\hline H3O & 82.55 & $\mathrm{a}$ & 63.55 & $a b c$ & 26.83 & $a b c$ & 24.00 & a \\
\hline H33 & 72.27 & $b c$ & 50.67 & de & 25.68 & $a b c d$ & 24.27 & a \\
\hline H36 & 65.20 & C & 40.10 & ef & 26.74 & $a b c$ & 24.52 & a \\
\hline H39 & 56.03 & $d$ & 40.59 & ef & 24.84 & bcde & 25.00 & a \\
\hline $\mathrm{H} 42$ & 52.51 & $\mathrm{de}$ & 41.82 & ef & 22.65 & def & 24.80 & a \\
\hline $\mathrm{H} 45$ & 43.65 & $\mathrm{e}$ & 40.76 & ef & 19.12 & $f$ & 24.30 & $\mathrm{a}$ \\
\hline $\mathrm{H} 48$ & 47.83 & de & 33.20 & $f$ & 21.18 & ef & 25.36 & a \\
\hline CV \% & 4.36 & & 9.84 & & 7.3 & & 11.77 & \\
\hline
\end{tabular}

1] Médias seguidas pela mesma letra na coluna não diferem, entre si, pelo Teste de Tukey (5\% de probabilidade). 


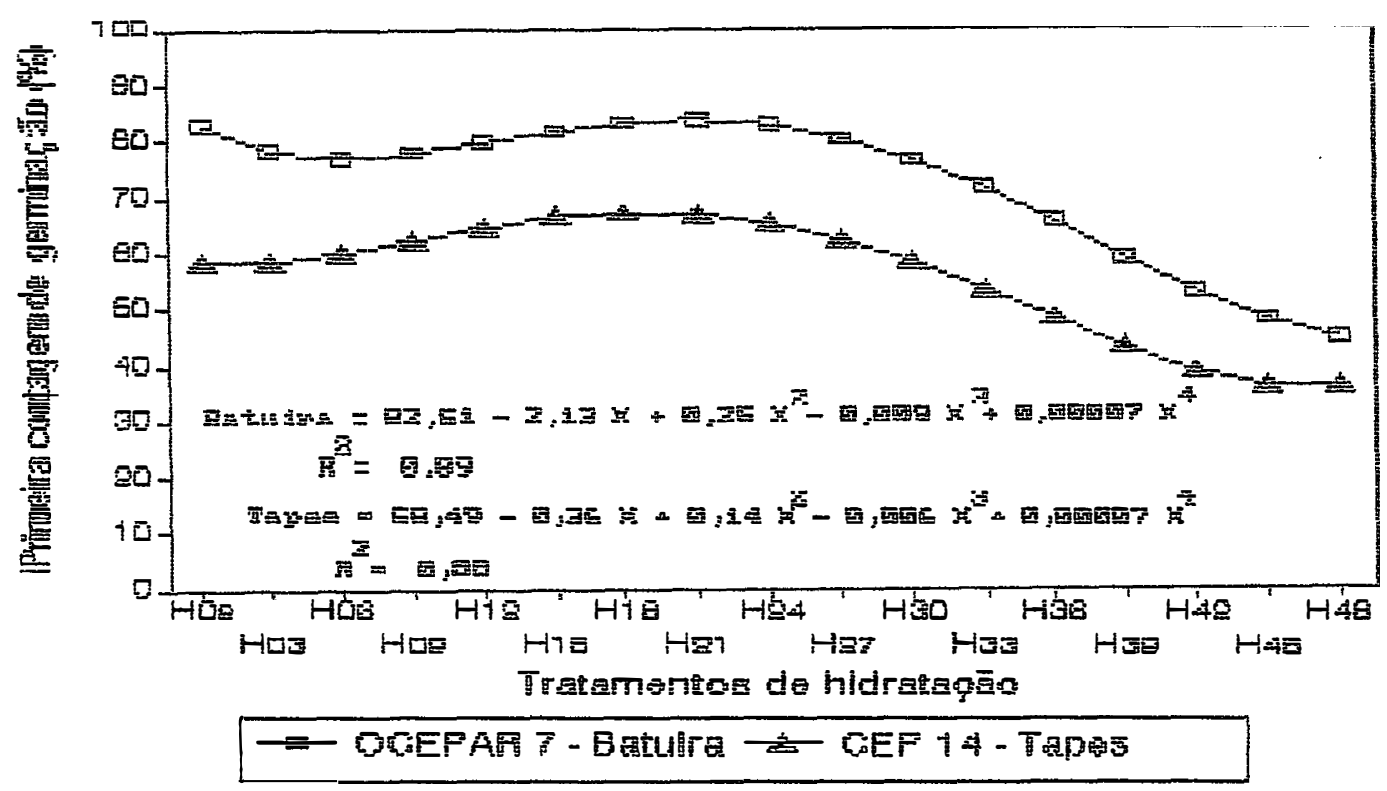

Figura 5. Estudo 1. Primeira contagem de germinação: curvas de regressão polinomial para os efeitos dos tratamentos de hidratação e secagem em sementes trigo dos cultivares OCEPAR 7 - Batuira e CEP 14 - Tapes.

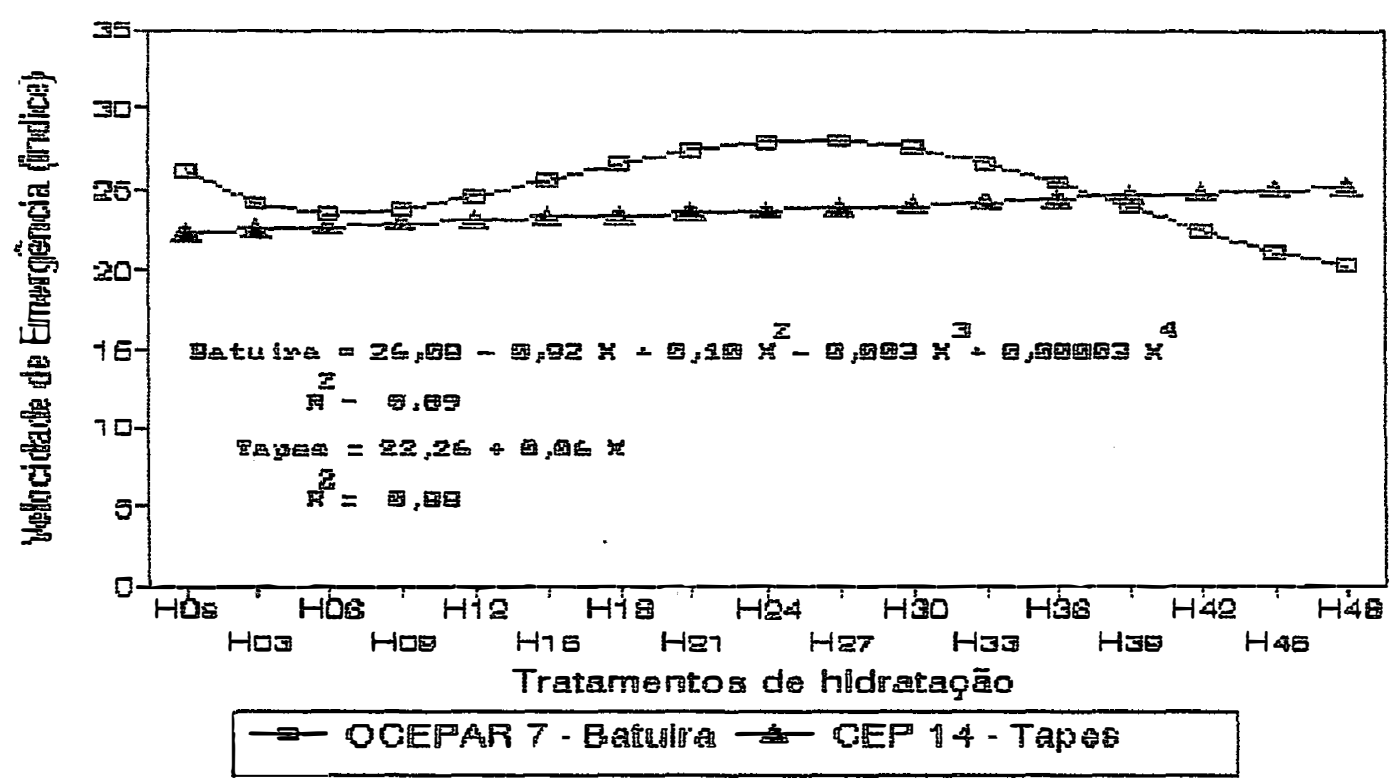

Figura 6. Estudo 1. Indice de velocidade de emergência em areia: curvas de regressão polinomial para os efeitos dos tratamentos de hidratação e secagem em sementes de trigo dos cultivares OCEPAR 7 Batuíra e CEP 14 - Tapes. 
Taxa de crescimento de plântula

A avaliação dos efeitos dos periodos de hidratação seguidos de secagem, no crescimento subsequente das plântulas, foi realizada através dos testes de comprimento e do peso de matéria seca.

Os dados, apresentados na Tabela 9 e nas Figuras 7 e 8 , mostram que, fixado o cultivar, os testes de comprimento e do peso de matéria seca de plântula, forneceram informações semelhantes quanto ao comportamento dos tratamentos.

Com relação ao cultivar OCEPAR 7 - Batuira, os dados obtidos nos dois testes indicam que nenhum tratamento superou a testemunha (HOS); em contrapartida, houve uma redução significativa na taxa de crescimento das plântulas, quando a desidratação foi efetuada nos períodos de hidratação superiores a 36 horas.

No caso do cultivar CEP 14 - Tapes, O comprimento das plântulas da testemunha (HOs) superou as hidratações de 33 a 48 horas e não diferiu dos demais tratamentos; os dados do peso da matéria seca, por sua vez, mostraram tendência de decréscimo com o aumento dos periodos de hidratação. Dessa forma, as hidratações, de um maneira geral, não trouxeram benefícios ao crescimento das plântulas havendo, inclusive, tendência ao surgimento de prejuizos com a ampliação dos periodos considerados. 
Tabela 9. Estudo 1. comparação entre as médias das avaliações do comprimento $(\mathrm{cm} / \mathrm{pl}$.$) e do peso de$ matéria seca (mg/pl.), das plântulas, para os efeitos dos tratamentos de hidratação (variáveis de 0 a 48 horas), seguidos de secagem, em sementes de trigo dos cultivares OCEPAR 7 Batuira e CEP 14 - Tapes.

\begin{tabular}{|c|c|c|c|c|c|c|}
\hline \multirow[b]{2}{*}{ Trat amentos } & \multicolumn{3}{|c|}{$\begin{array}{l}\text { Comprimento } \\
(\mathrm{cm} / \mathrm{p} 1 .)\end{array}$} & \multicolumn{3}{|c|}{$\begin{array}{c}\text { Peso de matéira seca } \\
(m g / p l .)\end{array}$} \\
\hline & Batuira & Tapes & & Batuira & Tapes & \\
\hline HOS & $22.03 a b$ & 20.37 & a & $11.26 \mathrm{a}$ & 11.81 & $a b c$ \\
\hline $\mathrm{HO} 3$ & $20.76 \mathrm{ab}$ & 19.71 & a & $11.02 \mathrm{a}$ & 11.78 & $a b c$ \\
\hline HO6 & $20.21 b$ & 20.05 & a & $10.99 a$ & 11.87 & $a b c$ \\
\hline $\mathrm{HOQ}$ & $22.28 \mathrm{ab}$ & 19.71 & a & $11.27 \mathrm{a}$ & 11.99 & $a b$ \\
\hline $\mathrm{H} 12$ & $21.97 \mathrm{ab}$ & 19.95 & $a$ & $11.12 \mathrm{a}$ & 11.86 & $a b c$ \\
\hline $\mathrm{H} 15$ & $22.28 \mathrm{ab}$ & 18.92 & $a b$ & $11.68 \mathrm{a}$ & 42.12 & a \\
\hline H1 8 & $22.19 a b$ & 19.11 & $a b$ & $11.60 \mathrm{a}$ & 11.73 & $a b c$ \\
\hline $\mathrm{H} 21$ & $22.59 \mathrm{ab}$ & 18.85 & $a b$ & $11.84 a$ & 11.81 & $a b c$ \\
\hline $\mathrm{H} 24$ & $23.66 \mathrm{a}$ & 20.51 & a & $11.86 a$ & 12.57 & a \\
\hline $\mathrm{H} 27$ & $22.70 \mathrm{ab}$ & 18.41 & $a b$ & $11.51 \mathrm{a}$ & 11.55 & $a b c$ \\
\hline $\mathrm{H} 30$ & $22.51 \mathrm{ab}$ & 18.64 & $a b$ & $11.77 \mathrm{a}$ & 11.66 & $a b c$ \\
\hline H33 & $21.84 \mathrm{ab}$ & 16.75 & $b c$ & $11.37 \mathrm{a}$ & 11.26 & abcd \\
\hline H36 & $20.70 \mathrm{ab}$ & 14.16 & $d$ & $10.92 a$ & 10.15 & cde \\
\hline H39 & $16.23 \mathrm{c}$ & 15.26 & $c d$ & $9.07 \mathrm{~b}$ & 9.69 & de \\
\hline $\mathrm{H} 42$ & $16.12 \mathrm{c}$ & 14.73 & $c d$ & $8.76 \mathrm{~b}$ & 10.28 & bcde \\
\hline $\mathrm{H} 45$ & $14.98 \mathrm{c}$ & 15.88 & $c d$ & $7.96 \mathrm{~b}$ & 10.25 & bcde \\
\hline $\mathrm{H} 48$ & $14.33 \mathrm{c}$ & 13.48 & $d$ & $7.66 \mathrm{~b}$ & 8.78 & e \\
\hline CV \% & 7.82 & 6.53 & & 7.49 & 7.61 & \\
\hline
\end{tabular}

1] Médias seguidas pela mesma letra na coluna não diferem, entre si, pelo Teste de Tukey (5\% de probabilidade). 


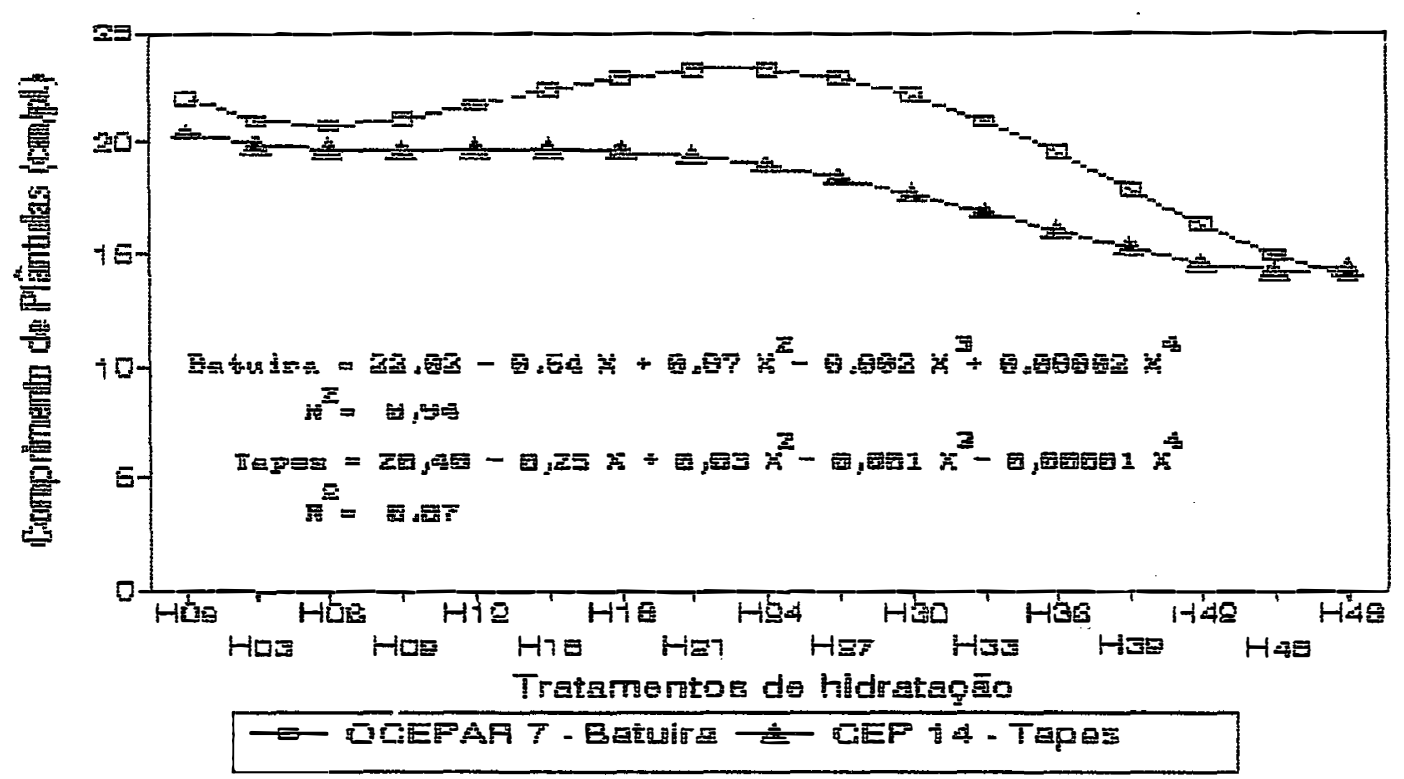

Figura 7. Estudo 1. Comprimento de plântulas: curvas regressão polinomial para os efeitos dos tratamentos de hidratação e secagem em sementes de trigo dos cultivares OCEPAR 7 - Batuira e CEP 14 - Tapes.

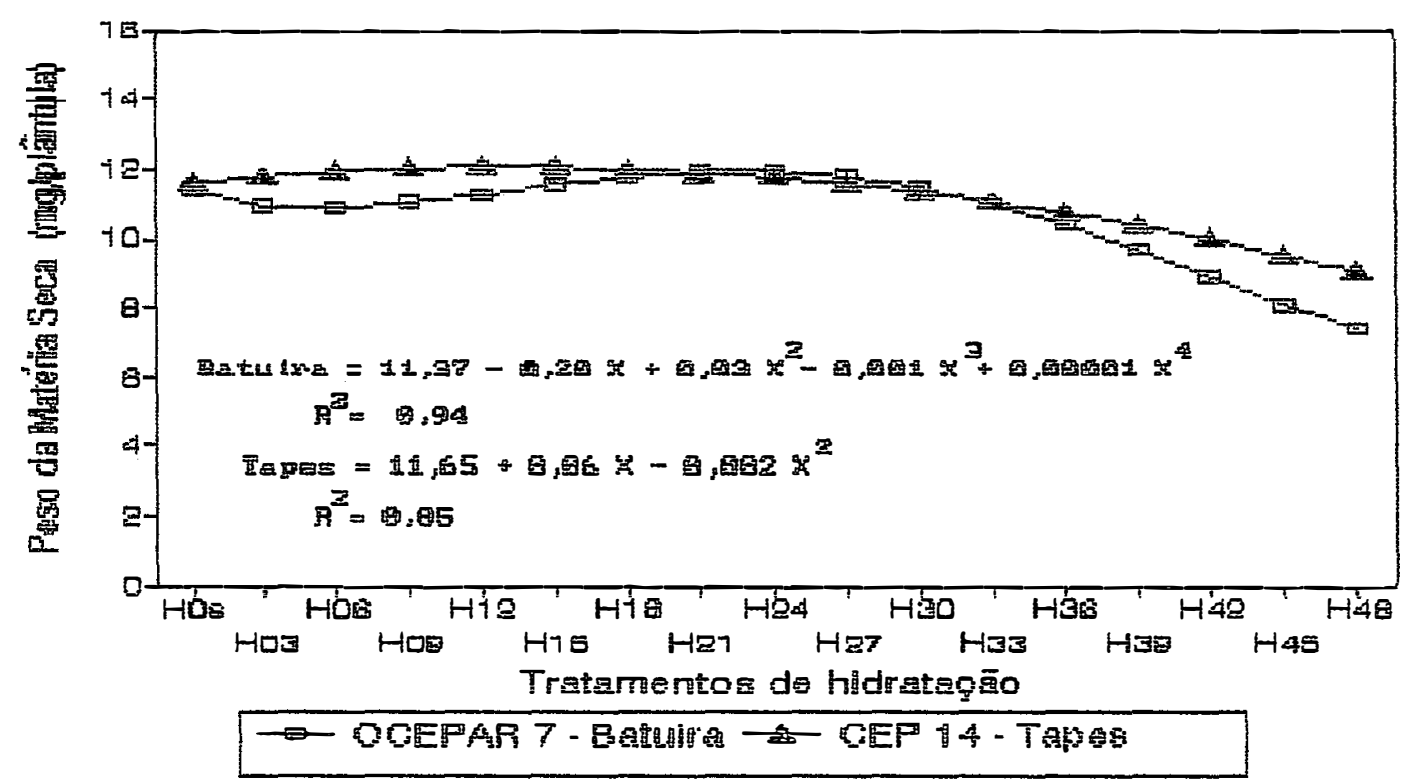

Figura 8. Estudo 1. Peso da matéria seca de plântulas: curvas de regressão polinomial para os efeitos dos tratamentos de hidratação e secagem, em sementes de trigo dos cultivares OCEPAR 7 Batuira e CEP 14 - Tapes. 


\section{Permeabilidade das membranas celulares}

A recuperação das membranas celulares, através dos tratamentos de hidratação, citada na literatura como relacionada ao controle da perda de eletrólitos celulares (SIMON, 1974; BRANLAGE et al., 1978; ROBERTS, 1981) foi, indiretamente, avaliada pelo teste de condutividade elétrica do meio de embebição das sementes. Os dados obtidos (Tabela 10 e Figura 9) mostraram que, nos dois cultivares, a testemunha (HOS) superou os tratamentos de hidratação com periodos maiores do que 33 horas. Houve, no entanto, uma tendência de redução na perda de eletrólitos nos periodos entre 12 e 24 horas de hidrat ação.

Admitindo a lixiviação de eletrólitos como uma expressão da deterioração (KOOSTRA, 1973; SIMON, 1974; VILLIERS \& EDGCUMBE, 1975; BASU, 1976; SIMON, 1984), OS resultados do teste de condutividade elétrica assemelhouse aos obtidos nos demais testes de vigor. Assim, embora tenha ocorrido uma de redução significativa na perda de eletrólitos para o meio de embebição, no cultivar CEP 14 Tapes nos periodos de 12 a 24 horas de hidratação, o mesmo não ocorreu, para o cultivar OCEPAR 7 - Batuira; por outro lado, a desidratação promoveu, em períodos de hidratação superiores a 30 horas, prejuízos à qualidade fisiológica das sementes de ambos os cultivares. 
Tabela 10. Estudo 1. Comparação entre as médias da determinação da condutividade elétrica do meio de embebição, para os efeitos de tratamentos de hidratação (variáveis de 0 a 48 horas) seguidos de secagem, em sementes de trigo dos cultivares OCEPAR 7 - Batuira e CEP 14 - Tapes.

\begin{tabular}{|c|c|c|}
\hline \multirow[b]{2}{*}{ Trat amentos } & OCEPAR 7 - Batuira & CEP 14 - Tapes \\
\hline & $\begin{array}{c}\text { médias }^{1} \\
(\text { Umhos } / \mathrm{cm} / \mathrm{g})\end{array}$ & $\begin{array}{c}\text { médias }^{1} \\
(\text { Umhos } / \mathrm{cm} / \mathrm{g})\end{array}$ \\
\hline HOS & $23.20 \mathrm{ab}$ & $23.28 \mathrm{bc}$ \\
\hline HO3 & $22.96 a$ & $23.23 \mathrm{bc}$ \\
\hline HO6 & $18.76 \mathrm{a}$ & $18.64 \mathrm{ab}$ \\
\hline HO9 & $18.52 \mathrm{a}$ & $20.10 a b c$ \\
\hline $\mathrm{H} 12$ & $21.40 \quad a$ & $17.15 \mathrm{a}$ \\
\hline $\mathrm{H} 15$ & $17.67 \mathrm{a}$ & $16.61 \mathrm{a}$ \\
\hline H18 & $21.11 \mathrm{a}$ & $16.60 \mathrm{a}$ \\
\hline $\mathrm{H} 21$ & $18.45 \mathrm{a}$ & $16.72 a$ \\
\hline $\mathrm{H} 24$ & $20.98 \quad a$ & $16.58 \mathrm{a}$ \\
\hline $\mathrm{H} 27$ & $22.70 \mathrm{a}$ & $20.35 a b c$ \\
\hline $\mathrm{H3O}$ & $28.72 b c$ & $23.91 \mathrm{c}$ \\
\hline H33 & $34.33 \mathrm{c}$ & $30.43 \mathrm{~d}$ \\
\hline H36 & $42.71 \mathrm{~d}$ & $36.35 \mathrm{e}$ \\
\hline H39 & $42.78 \mathrm{~d}$ & $42.86 f$ \\
\hline $\mathrm{H} 42$ & $48.69 \mathrm{e}$ & $47.34 \mathrm{fg}$ \\
\hline $\mathrm{H} 45$ & $54.24 \mathrm{e}$ & $51.90 \mathrm{~g}$ \\
\hline $\mathrm{H} 48$ & $65.17 \mathrm{f}$ & $57.16 \mathrm{~h}$ \\
\hline CV \% & 8.94 & 8.85 \\
\hline
\end{tabular}

1] Médias seguidas pela mesma letra na coluna não diferem, entre si, pelo Teste de Tukey (5\% de probabilidade). 


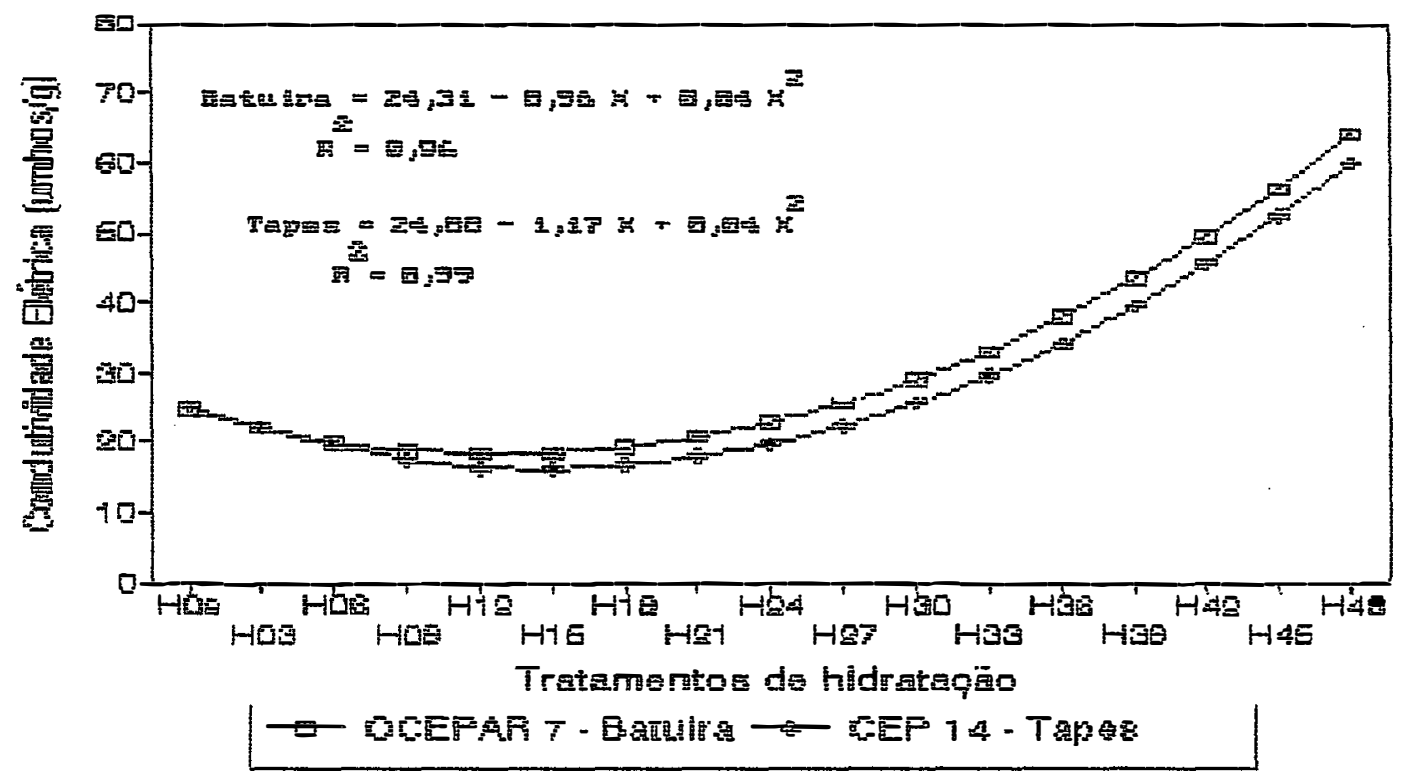

Figura 9. Estudo 1. Condutividade elétrica do meio de embebição: curvas de regressão polinomial para os efeitos dos tratamentos de hidratação e secagem em sementes de trigo dos cultivares OCEPAR 7 - Batuíra e CEP 14 - Tapes.

\subsubsection{Avaliação da sanidade das sementes}

Nesta avaliação não houve a intenção de detectar os efeitos dos microrganismos no desempenho das sementes e nem tampouco, a de comparar os efeitos dos tratamentos de hidratação com os habitualmente empregados no controle de patógenos. O objetivo foi o de verificar a existência de efeitos dos tratamentos de hidratação/ secagem na ocorrência de alguns microrganismos comumente associados às sementes de trigo (MEHTA, 1978; MEHTA et a)., 1987; REIS, 1987).

Os dados apresentados (Figuras 10 e 11), referem-se aos das espécies de fungos mais importantes, 
detectadas nas sementes de ambos os cultivares, quer pelo nivel de ocorrência, quer pela importância econômica para a cultura. A Figura 10 mostra a variação das médias de frequências observadas para o fungo Helminthosporium spp. que, dentro das espécies originárias de infecção em campo e transmissiveis pela semente, representa um dos patógenos mais importantes para a cultura do trigo (MEHTA et a1., 1987). A Figura 11, por outro lado, apresenta a variação da soma das porcentagens de ocorrência dos principais fungos de armazenamento (Aspergilius spp. e Penicilium spp.). A variação da porcentagem de sementes isentas de fungos, em função dos tratamentos de hidratação/ desidratação é apresentada na Figura 12 .

$$
\text { Os dados obtidos, nas avaliações da }
$$
sanidade das sementes, não foram submetidos à análise estatística; e, portanto, serão consideradas, na discussão dos resultados apresentados nas Figuras 10,11 e 12 , apenas as tendências das variações observadas em função dos tratamentos empregados.

A Figura 10 mostra uma leve tendência de queda, na incidência do fungo Helminthosporium spp., até o tratamento $\mathrm{H} 27$, com posterior elevação nas frequências que, a partir de H33, foram superiores em valores absolutos à testemunha Ho. Uma pequena queda, na incidência do patógeno, devida ao ambiente de secagem, pode ser observada, ao serem comparadas as frequências 
obtidas pelas testemunhas HO e HOS; entretanto, os tratamentos mais favoráveis à redução de ocorrência do fungo de campo foram aqueles com períodos de hidratação situados no intervalo de 15 a 27 horas.

Com relação às espécies de fungos de armazenamento (Aspergillus e Penicillium), a Figura 11 mostra que, comparados aos dados obtidos pela testemunha HO (sem hidratação) em ambos os cultivares, houve redução no nivel de ocorrência dos fungos nas sementes da testemunha submetida às condições de secagem (HOs) e nos tratamentos situados entre 12 e 27 horas de hidratação.

Considerando as porcentagens de ocorrência de sementes isentas de patógenos (Figura 12), observa-se, para ambos cultivares, que a sanidade foi favorecida, em relação as testemunha HO e HOS, nos tratamentos envolvendo períodos de hidratação entre 15 e 24 horas; por outro 1ado, períodos de hidratação, seguidos de secagem, inferiores a 9 horas e superioes a 33 horas, favoreceram o desenvolvimento dos microrganismos. Foi possivel constatar relações entre a porcentagem de ocorrência de fungos e a variação observada em algumas avaliações de desempenho: um crescimento de incidência nos períodos mais curtos de hidratação, seguido de um decréscimo nos períodos intermediários e de novo crescimento nos períodos mais longos de hidratação. 


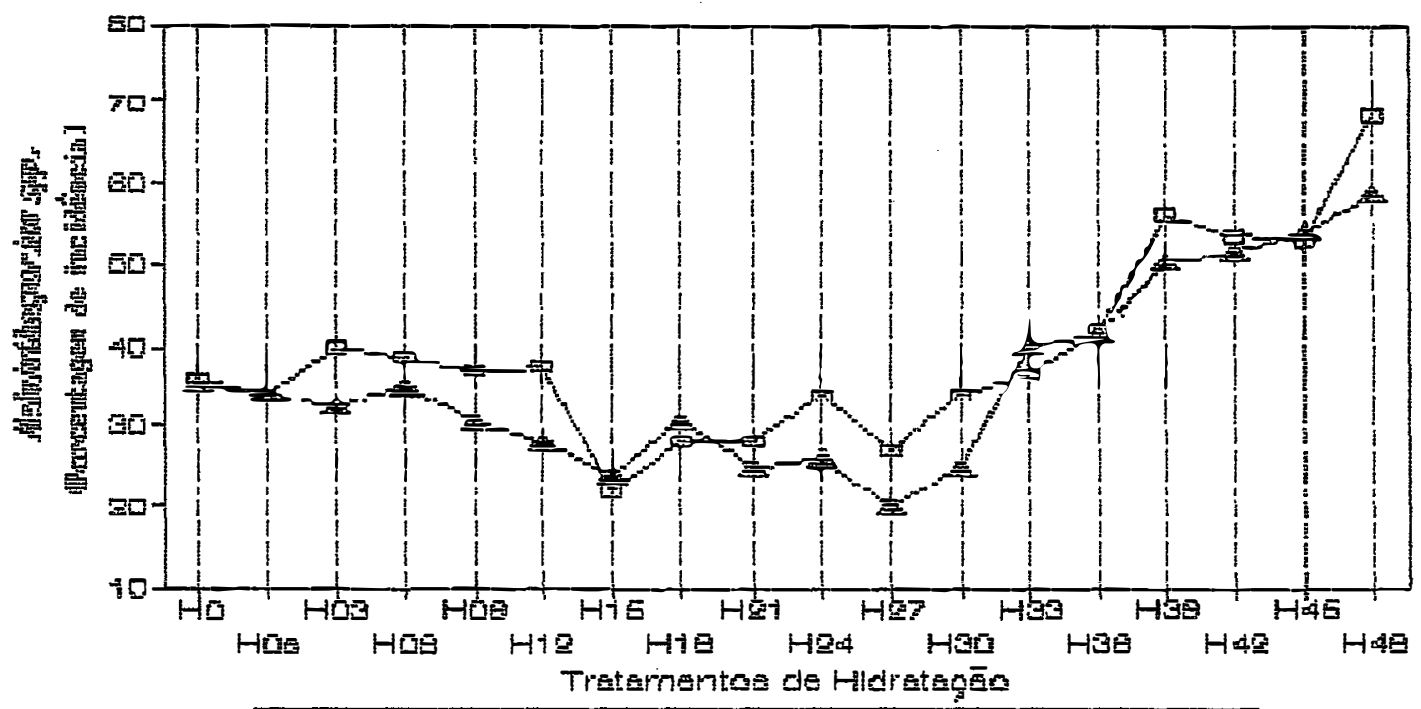

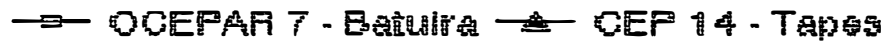

Figura 10. Estudo 1. Fungo de campo Helminthosporium spp: variação nos valores médios de incidência (\%), em função do tratamento de hidratação e secagem, nas sementes de trigo dos cultivares OCEPAR 7 - Batuíra e CEP 14 - Tapes.

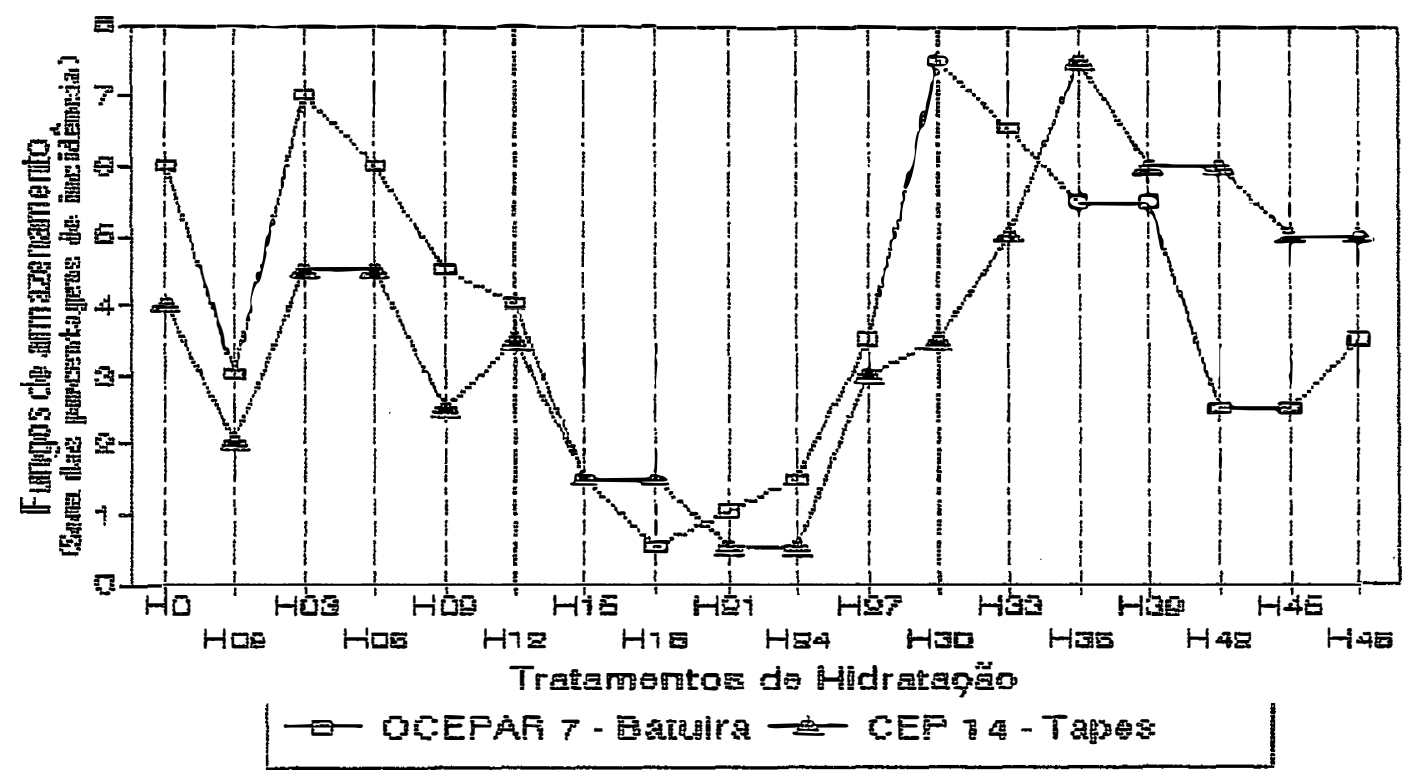

Figura 11. Estudo 1. Fungos de armazenamento Penicilium spp. e Aspergillus spp.: variação na soma dos valores médios de incidência (\%), em função do tratamento de hidratação e secagem, nas sementes dos cultivares de trigo OCEPAR 7 Batuira e CEP 14 - Tapes. 


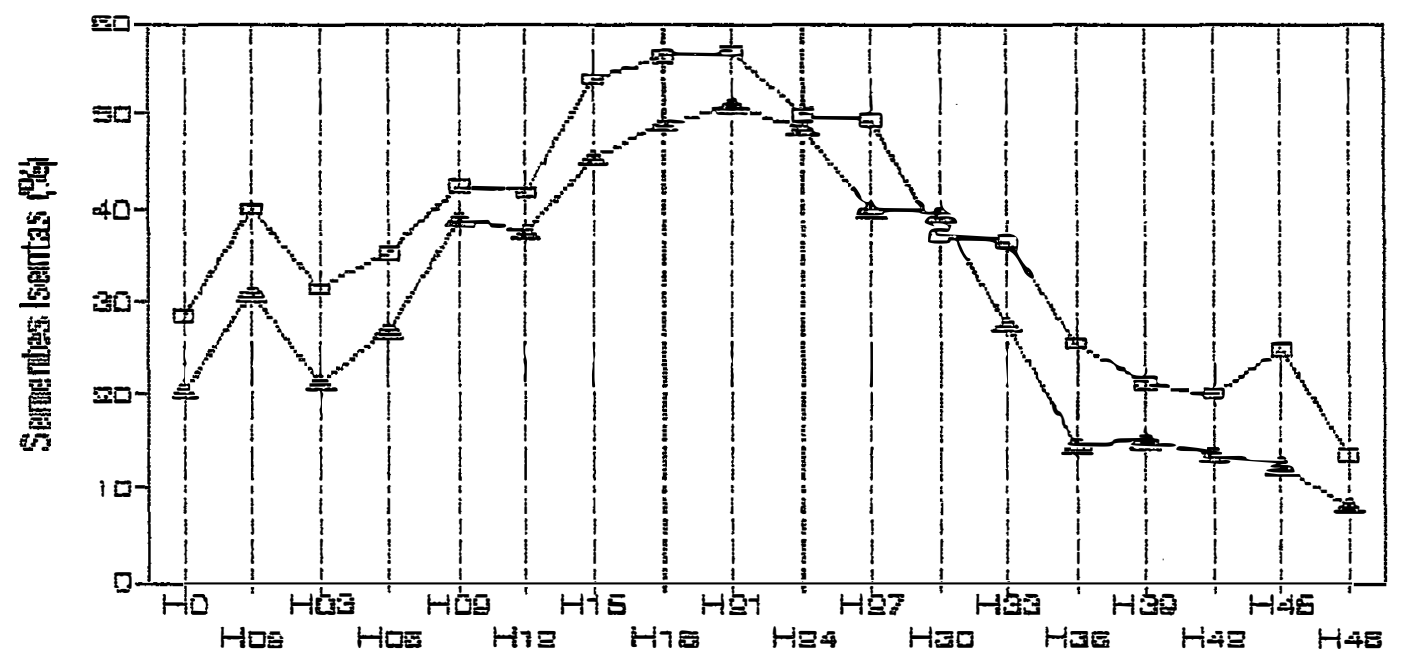

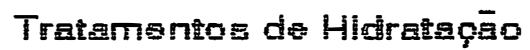

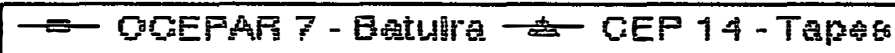

Figura 12. Estudo 1. Sementes isentas de patógenos: variação nos valores médios de ocorrência (\%) em função do tratamento de hidratação e secagem, para os cultivares de trigo OCEPAR 7 - Batuíra e CEP 14 - Tapes.

observa-se, no entanto, que as condições empregadas, durante a secagem, foram suficientes para reduzir a porcentagem de ocorrência dos patógenos, principalmente, çom relação aos fungos de armazenamento. Aparentemente, a secagem das sementes após os períodos mais longos de hidratação, não afetou o desenvolvimento dos fungos de campo; contudo, os fungos de armazenamento apresentaram um comportamento cíclico, com elevação de incidência nos períodos mais curtos de hidratação (de 3 a 9 horas), redução nos períodos intermediários (de 15 a 24 horas), novo crescimento nos períodos de 27 a 36 horas e, finalmente, nova redução nos períodos superiores. 


\subsubsection{Considerações gerais}

Numa avaliação geral dos resultados pode ser constatado que, para a maioria dos fatores avaliados e, independentemente do cultivar, nenhum dos tratamentos realizados trouxe benefícios, significativos, à qualidade das sementes (exceção feita para os resultados obtidos pelas sementes do cultivar CEP 14 - Tapes nos tratamentos H18 e H27 no teste de primeira contagem de germinação e pelos tratamentos de $\mathrm{H} 12$ a $\mathrm{H} 24$ no teste de condutividade elétrica do meio de embebição). A ausência respostas positivas pode, entretanto, ter ocorrido em função da alta qualidade inicial dos lotes; segundo alguns autores (BASU, 1976; GOLDSWORTHY et a1., 1982; WARD \& POWELL, 1983) os efeitos dos tratamentos são mais evidentes em sementes com maior nível de deterioração. Apesar disso, foram detectados, entre os intervalos de hidratação, alguns que forneceram respostas, mais ou menos, favoráveis ao desempenho das sementes; por exemplo, hidratações de períodos curtos (entre 3 e 12 horas) parecem ser menos adequadas do que as dos períodos intermediários (entre 15 e 27 horas); estes tratamentos (H15 a H27), apesar de não diferirem significativamente da testemunha (HOs), forneceram, na maioria dos casos, os melhores resultados e eram representados por sementes que não haviam emitido a raíz primária e encontravam-se no intervalo de hidratação onde a velocidade de absorção de água foi menor (Tabelas 
5 e 6, Figura 2). Por outro 1ado, houve tratamentos de hidratação/secagem que provocaram redução na qualidade inicial das sementes, principalmente os de periodos de hidratação superiores a 30 horas. o declinio significativo no desempenho, observado nos periodos de hidratação superiores a 30 horas, coincidiu com o inicio da emissão radicular, momento referido, por alguns autores, como o do limite de tolerância à desidratação. Contudo, não houve correspondência proporcional entre a evolução no número de individuos com raizes emitidas e o decréscimo no desempenho fisiológico, significando que algumas sementes, portadoras de raíz primária, permaneceram tolerantes à desidratação; este fato conduziu à necessidade de avaliar, isoladamente, o desempenho dos individuos em função do estádio de desenvolvimento em que se encontravam dentro de cada período de hidratação (Estudo 2).

Comparando os resultados da incidência de patógenos com o desempenho fisiológico das sementes, verifica-se que há uma correspondência entre ambos, o que pode conduzir a três proposições. A primeira diz respeito à atividade dos patógenos como fator de redução no desempenho fisiológico das sementes; ou seja, uma condição mais favorável ao desenvolvimento dos microorganismos, encontrada nos periodos mais longos de hidratação, pode ter contribuido para sua maior incidência, sendo esta a responsável pelos danos à performance das sementes; a 
segunda, refere-se à perda da eficiência dos mecanismos de resistência presentes na semente, provocada pela secagem nos períodos de hidratação mais prolongados; a última possibilidade e, talvez, a mais evidente, diz respeito às alterações, promovidas pelos tratamentos, na permeabilidade das membranas celulares o que reflete, diretamente, na disponibilidade de nutrientes necessários ao desenvolvimento e à atividade dos microrganismos (SHORT \& LACY, 1976; KRAFT, 1977; HALLOIN, 1983). Nesse sentido, pode-se verificar a relação entre a tendência observada nos resultados do teste de condutividade elétrica e a variação na incidência dos fungos. 


\subsection{Estudo 2.}

Este estudo, realizado apenas com o cultivar OCEPAR 7 - Batuíra, teve como objetivo relacionar o desempenho das sementes com o estádio de desenvolvimento alcançado nos diferentes períodos de hidratação. o agrupamento de estádios, bem como a simbologia adotada acham-se apresentadas Tabelas 3.

\subsubsection{Caracterização dos grupos de estádios de desenvolvimento das sementes}

Foi realizada, considerando a distribuição do porcentagem de ocorrência de sementes representantes dos grupos de desenvolvimento (Tab.11) e seus respectivos conteúdos de água (Tab. 11 e Fig. 13), nas amostras obtidas de cada período de hidratação

A observação da Tabela 11 permite verificar que, os grupos I, I I e IV predominaram, respectivamente, nos intervalos $\mathrm{H} 03-\mathrm{H} 21, \mathrm{H} 24-\mathrm{H} 42$ e $\mathrm{H} 45-\mathrm{H} 48$; O grupo III, em nenhuma hidratação, apresentou frequências que o tornou predominante na população. Verificou-se, ainda, ampliação na variabilidade da população à medida em que era aumentado o tempo de hidratação; dessa forma, entre 36 e 48 horas, todos os grupos de desenvolvimento estiveram presentes. 
Tabela 11. Estudo 2. Distribuição (\%) da ocorrência na população de cada período de hidratação e teor de água de sementes agrupadas segundo o estádio de desenvolvimento atingido no processo de germinação.

\begin{tabular}{|c|c|c|c|c|c|c|c|c|}
\hline \multirow{3}{*}{$\begin{array}{l}\text { Períodos } \\
\text { de } \\
\text { Hidratação } \\
\text { (horas) }\end{array}$} & \multicolumn{8}{|c|}{ Grupos de Desenvolvimento } \\
\hline & \multicolumn{2}{|l|}{ I } & \multicolumn{2}{|l|}{ II } & \multicolumn{2}{|l|}{ III } & \multicolumn{2}{|l|}{ IV } \\
\hline & $\begin{array}{c}\text { Ocorrência } \\
(y)\end{array}$ & $\begin{array}{l}\mathrm{H}_{2} \mathrm{O} \\
(\mathrm{W})\end{array}$ & $\begin{array}{c}\text { Ocorrência } \\
(8)\end{array}$ & $\begin{array}{l}\mathrm{H}_{2} \mathrm{O} \\
(\mathrm{O})\end{array}$ & $\begin{array}{c}\text { Ocorrência } \\
(\%)\end{array}$ & $\begin{array}{l}\mathrm{H}_{2} \mathrm{O} \\
(\%)\end{array}$ & $\begin{array}{c}\text { Ocorrência } \\
(\%)\end{array}$ & $\begin{array}{l}\mathrm{H}_{2} \mathrm{O} \\
(\mathrm{y})\end{array}$ \\
\hline os & 0 & 12,02 & 0 & - & 0 & - & 0 & - \\
\hline 03 & 100 & 19.91 & 0 & - & 0 & - & 0 & - \\
\hline 06 & 100 & 25.28 & 0 & - & 0 & - & 0 & - \\
\hline 09 & 100 & 29.76 & 0 & - & 0 & - & 0 & - \\
\hline 12 & 95 & 33.43 & 5 & - & 0 & - & 0 & - \\
\hline 15 & 88 & 36.38 & 12 & 42.01 & 0 & - & 0 & - \\
\hline 18 & 80 & 38.70 & 20 & 42.45 & 0 & - & 0 & - \\
\hline 21 & 62 & 40.48 & 38 & 42.89 & 0 & - & 0 & - \\
\hline 24 & 45 & 41.82 & 55 & 43.33 & 0 & - & 0 & - \\
\hline 27 & 27 & 42.79 & 72 & 43.78 & 1 & 47,13 & 0 & - \\
\hline 30 & 17 & 43.49 & 81 & 44.22 & 2 & 47.00 & 0 & - \\
\hline 33 & 11 & 44.02 & 83 & 44.66 & 6 & 46.17 & 0 & $=$ \\
\hline 36 & 08 & 44.45 & 71 & 45.10 & 17 & 45.68 & 4 & 51.69 \\
\hline 39 & 06 & 44.88 & 49 & 45.55 & 35 & 45.54 & 10 & 52.45 \\
\hline 42 & 05 & 45.41 & 38 & 45.99 & 36 & 45.75 & 21 & 54.70 \\
\hline 45 & 05 & 46.12 & 28 & 46.43 & 23 & 46.31 & 44 & 57.65 \\
\hline 48 & 05 & 47.09 & 17 & 46.87 & 20 & 47.22 & 58 & 60.51 \\
\hline
\end{tabular}




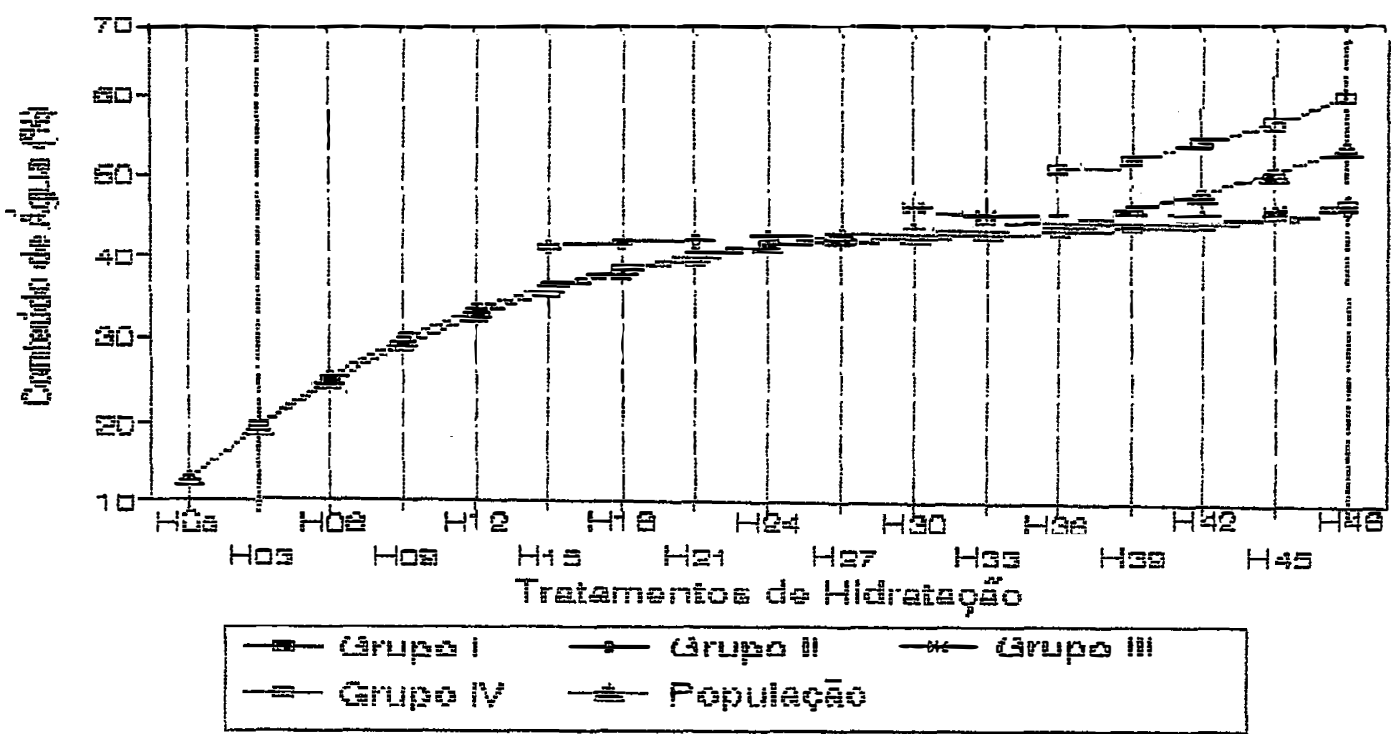

Figura 13. Estudo 2. Conteúdo (\%) de água de sementes distribuidas em grupos estabelecidos, de acordo com o estádio de desenvolvimento germinativo alcançado, em períodos de hidratação variáveis.

A Tabela 11 e Figura 13 indicam que, até o tratamento H33 e fixado o período de hidratação, os grupos mais avançados de desenvolvimento tenderam a apresentar teores de água superiores aos dos demais. Contudo, a partir de $\mathrm{H} 36$, os teores de água nos grupos I, I I e II mantiveram-se similares entre si e inferiores aos do grupo IV. Foram verificadas acréscimos decrescentes, no de teor de água das sementes do grupo I, com o aumento do periodo de hidratação; enquanto que os grupos II e III, mantiveram teores de água praticamente constantes em todos os periodos em que foram obtidos; o grupo IV, por sua vez, apresentou maiores acréscimos do que os dos demais grupos. Segundo HEGARTY (1978), a hidratação das sementes, de um mesmo lote, ocorre em diferentes taxas 
para cada individuo; havendo sementes que, não germinadas, apresentam teor de água similar ou superior ao das germinadas. ABDUL - BAKI \& ANDERSON (1972), por sua vez, sugerem que, quanto mais baixo o vigor da semente, maior é - seu requerimento de água para germinar. Estes relatos podem explicar a presença de teores de água equivalentes em grupos de desenvolvimento distintos e a existência de teores de água distintos em um mesmo grupo.

4.2.2. Desempenho fisilógico de sementes reunidas em grupos de desenvolvimento.

\section{Viabilidade das sementes}

Os dados obtidos nos testes de germinação e de emergência em areia (Tab.12 e 13 e Fig. 14 e 15) mostram que os grupos de desenvolvimento, observados isoladamente, tenderam a perder desempenho com a ampliação do periodo de hidratação em que foram obtidos. Por outro lado, os individuos mais precoces dos grupos II, III e IV na germinação e I I e IV na emergência, apresentaram melhor desempenho, em valores absolutos, que a testemunha HOs. Observados os tratamentos de hidratação, verifica-se que a população total, GII, GIII e GIV mantiveram resultados semelhantes entre si, enquanto GI, a partir de H15, tendeu a ser inferior aos demais. Considerando que o retardamento da germinação é um dos sinais da perda vigor e que, sementes mortas são capazes 
de manter o padrão de hidratação representado pelo pelo grupo I (BEWLEY \& BLACK, 1985), os individuos desse grupo, presentes nas amostras dos periodos mais avançados de hidratação, devem, portanto, pertencer à categoria de sementes de menor vigor ou ao das não viáveis.

As sementes do grupo II, por sua vez, mostraram comportamento semelhante ao da população total superando-a, contudo, nos periodos de 15 e de 21 horas de hidratação. As representantes do grupo II I superaram, as dos grupos menos avançados de desenvolvimento e a população total, apenas nos periodos iniciais do seu surgimento ( 30 a 33 horas de hidratação); as sementes, desse grupo, obtidas nos periodos posteriores, mostraram desempenhos decrescentes até não se igualarem à população tota1. o grupo IV apresentou um comportamento análogo ao do grupo III, sendo significativamente superior aos demais grupos nos periodos de hidratação em que surgiram pela primeira vez; nos periodos maiores de hidratação, apresentaram resultados decrescentes, até se aproximarem dos resultados da população total e dos grupos I I e II I. Os dados sugerem que a porção de sementes que, num dado periodo de hidratação, atingem estádios mais avançados de desenvolvimento, representam os individuos de maior vigor da população e, portanto, aqueles que possuem maior capacidade de resistir à desidratação subsequente. 
Tabela 12. Estudo 2. Germinação: valores médios (\%) obtidos pela população total de sementes e pelos grupos formados, em função do estádio de desenvolvimento germinativo atingido, após tratamentos de hidratação (variáveis de 0 a 48 horas) que precederam a secagem.

\begin{tabular}{|c|c|c|c|c|c|c|c|c|c|c|c|}
\hline \multirow{2}{*}{$\begin{array}{l}\text { Tratamentos } \\
\text { de } \\
\text { Hidratação }\end{array}$} & \multirow{2}{*}{$\begin{array}{l}\text { População } \\
\text { Total }\end{array}$} & & \multicolumn{7}{|c|}{ Grupos de desenvolvimento } & & \multirow{2}{*}{$\begin{array}{l}C V \\
(y)\end{array}$} \\
\hline & & & GI & & GII & & G III & & G IV & & \\
\hline HOS & 83.73 & a & - & & - & & - & & - & & - \\
\hline $\mathrm{HO3}$ & 82.02 & $a b$ & - & & - & & - & & - & & - \\
\hline HOG & 84.20 & $a$ & - & & - & & - & & - & & - \\
\hline HOS & 81.42 & $a b$ & - & & - & & - & & - & & - \\
\hline H12 & 80.17 & $a b$ & - & & - & & - & & - & & - \\
\hline $\mathrm{H} 15$ & $84.98^{B}$ & a & $81.28^{B}$ & $a b$ & $97.38 \mathrm{~A}$ & $a$ & - & & - & & 11.8 \\
\hline H18 & $83.49^{A}$ & a & $83.86^{A}$ & a & $77.60^{\mathrm{A}}$ & bcde & - & & - & & 11.8 \\
\hline H21 & $86.70^{B}$ & $a$ & $80.92^{B}$ & $a b$ & $94.48^{A}$ & $a b$ & - & & - & & 11.8 \\
\hline H24 & $84.28 \mathrm{~A}$ & a & $84.06^{A}$ & a & $83.92^{A}$ & abcd & - & & - & & 11.8 \\
\hline H27 & $86.99 \mathrm{~A}$ & a & $87.72^{A}$ & $a$ & $87.69^{A}$ & abcd & - & & - & & 11.8 \\
\hline H3O & $84.54^{B}$ & $a$ & $60.44^{C}$ & bc & $91.59 \mathrm{AB}$ & $a b c$ & $97.19 \mathrm{~A}$ & $a$ & - & & 12.6 \\
\hline H33 & $75.92^{\mathrm{B}}$ & $a b c$ & $45.97^{\mathrm{C}}$ & cd & $78.51^{B}$ & bcde & $95.10^{\mathrm{A}}$ & $a$ & - & & 12.6 \\
\hline H36 & $71.39^{B}$ & abcd & $40.28^{C}$ & code & $73.51^{B}$ & cde & $81.48^{B}$ & b & $98.24^{A}$ & a & 13.6 \\
\hline H39 & $70.74^{A B}$ & $a b c d$ & $60.13^{B}$ & bc & $74.11^{A B}$ & cde & $69.07 \mathrm{AB}$ & bc & $80.38 \mathrm{~A}$ & b & 13.6 \\
\hline H42 & $66.22 \mathrm{~A}$ & bed & $31.43^{B}$ & de & $67.09 \mathrm{~A}$ & de & $68.17^{\mathrm{A}}$ & bc & $59.62^{A}$ & c & 13.6 \\
\hline $\mathrm{H} 45$ & $55.84 \mathrm{~A}$ & $d$ & $32.83^{B}$ & de & $55.39 \mathrm{~A}$ & e & $50.17 \mathrm{AB}$ & c & $61.19 \mathrm{~A}$ & c & 13.6 \\
\hline H48 & $60.36 \mathrm{~A}$ & cd & $18.41^{B}$ & e & $59.69 \mathrm{~A}$ & e & $55.79^{A}$ & c & $69.44^{\mathrm{A}}$ & $b c$ & 13.6 \\
\hline $\operatorname{CV}(\%)=$ & 9.5 & & 13.6 & & 13.6 & & 12.5 & & 13.6 & & \\
\hline
\end{tabular}

Médias seguidas pela mesma letra maiúscula na linha e letra minúscula na coluna não diferem entre si pelo Teste de Tukey (5\% de probabilidade). 
Tabela 13. Estudo 2. Emergência em areia: valores médios (\%) obtidos pela população total de sementes e pelos agrupamentos formados, em função do estádio de desenvolvimento germinativo atingido, após os tratamentos de hidratação (variáveis de 0 a 48 h) que precederam a secagem.

\begin{tabular}{|c|c|c|c|c|c|c|c|c|c|c|c|}
\hline \multirow{2}{*}{$\begin{array}{l}\text { Tratamentos } \\
\text { de } \\
\text { Hidratação }\end{array}$} & \multirow{2}{*}{$\begin{array}{c}\text { População } \\
\text { Total }\end{array}$} & & \multicolumn{7}{|c|}{ Grupos de desenvolvimento } & & \multirow{2}{*}{$\begin{array}{l}C V \\
\left(\begin{array}{l}0 \\
y\end{array}\right)\end{array}$} \\
\hline & & & 1 & & II & & III & & IV & & \\
\hline HOS & 85.54 & $a b c$ & - & & - & & - & & - & & - \\
\hline HO3 & 83.40 & abcd & - & & - & & - & & - & & - \\
\hline HOG & 80.54 & abcd & - & . & - & & - & & - & & - \\
\hline HOg & 82.13 & $a b c d$ & - & & - & & - & & - & & - \\
\hline$H 12$ & 83.78 & abcd & - & & - & & - & & - & & - \\
\hline H15 & $84.60^{B}$ & $a b c$ & $83.91^{B}$ & a & $98.48^{A}$ & $a$ & - & & - & & 11.3 \\
\hline$H 18$ & $85.87^{A}$ & $a b$ & $84.91 \mathrm{~A}$ & a & $87.50^{A}$ & bc & - & & - & & 11.3 \\
\hline H21 & $85.54 \mathrm{AB}$ & $a b c$ & $83.02^{B}$ & a & $94.08 \mathrm{~A}$ & $a b$ & - & & - & & 11.3 \\
\hline H24 & $87.07^{A B}$ & $a b$ & $78.37^{B}$ & $a b$ & $90.73^{A}$ & $a b c$ & - & & - & & 11.3 \\
\hline H27 & $89.35^{A}$ & $a$ & $75.85^{B}$ & $a b$ & $90.90^{A}$ & $a b c$ & - & & - & & 11.3 \\
\hline H30 & $83.40^{\mathrm{A}}$ & $a b c d$ & $58.74^{B}$ & $b c$ & $87.31^{A}$ & $b c$ & $79.91 \mathrm{~A}$ & $a b$ & - & & 10.9 \\
\hline H33 & $77.53^{A B}$ & abcd & $52.69 \mathrm{C}$ & c. & $83.33^{A}$ & bcd & $69.34^{B}$ & $b$ & - & & 10.9 \\
\hline H36 & $77.44^{B}$ & $a b c d$ & $48.93^{C}$ & $c$ & $79.55^{B}$ & bed & $89.73^{B}$ & a & $98.24 \mathrm{~A}$ & a & 12.3 \\
\hline H39 & $77.02^{A}$ & $a b c d$ & $53.54^{B}$ & $c$ & $76.76^{A}$ & cde & $85.48^{A}$ & $a b$ & $90.58 \mathrm{~A}$ & $a b$ & 12.3 \\
\hline H42 & $70.48^{A}$ & bcd & $38.95^{B}$ & cd & $78.15^{\mathrm{A}}$ & cde & $72.40^{\mathrm{A}}$ & $b$ & $80.24^{\mathrm{A}}$ & bc & 12.3 \\
\hline $\mathrm{H} 45$ & $64.68 \mathrm{~A}$ & $d$ & $18.94^{B}$ & de & $64.36^{A}$ & de & $68.19 \mathrm{~A}$ & $b$ & $65.68 \mathrm{~A}$ & $c$ & 12.3 \\
\hline$H 48$ & $66.79 \mathrm{~A}$ & cd & $16.94^{B}$ & e & $57.89^{A}$ & e & $73.16^{A}$ & $b$ & $72.27 \mathrm{~A}$ & $c$ & 12.3 \\
\hline $\operatorname{CV}(y)=$ & 11.0 & & 11.9 & & 11.9 & & 10.9 & & 12.3 & & \\
\hline
\end{tabular}

Médias seguidas pela mesma letra maiúscula na linha e letra minúscula na coluna não diferem entre si pelo Teste de Tukey (5o de probabilidade). 


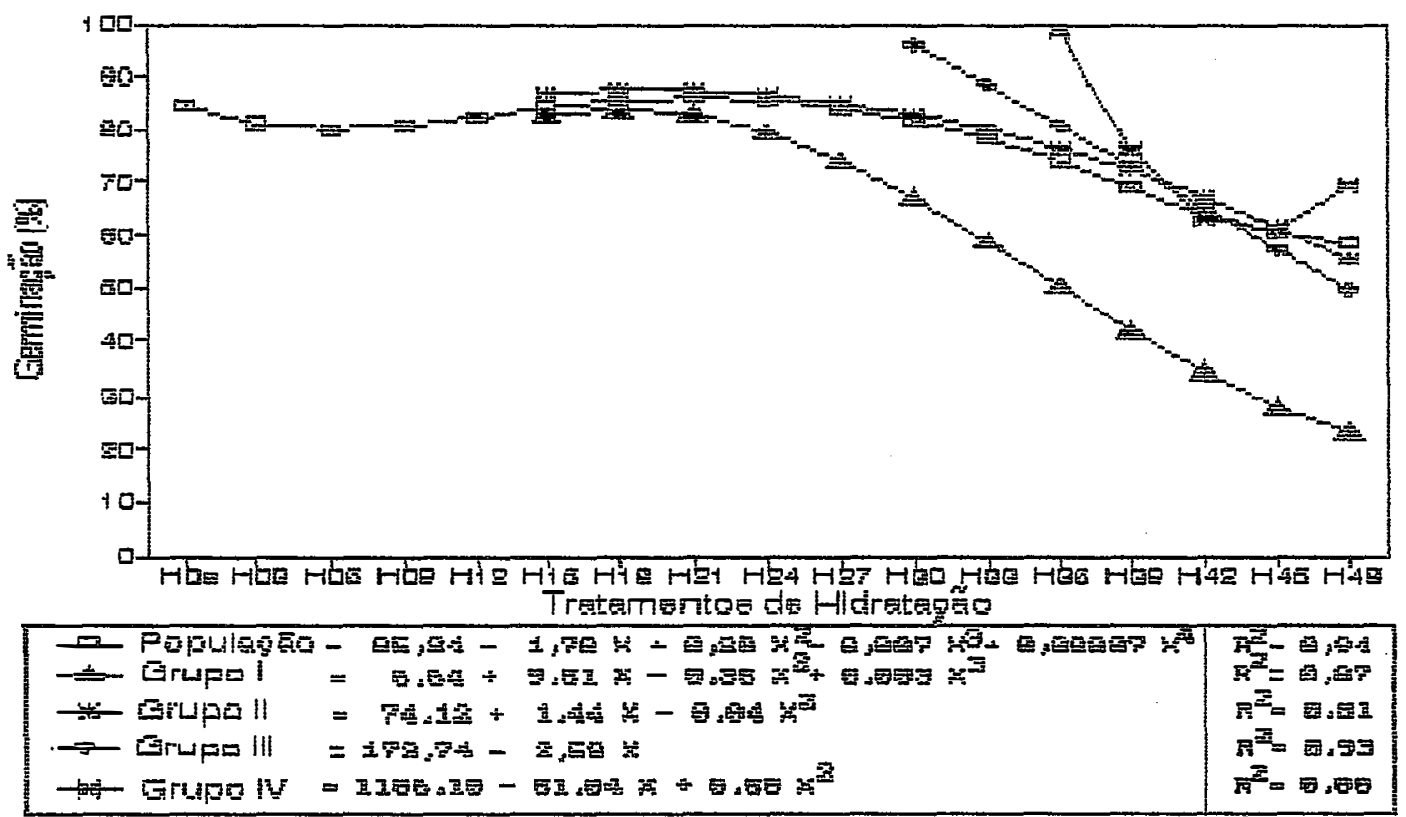

Figura 14. Estudo 2. Germinação: curvas de regressão polinomial para os efeitos dos tratamentos de hidratação e secagem, em sementes de trigo (cv. Batuira) agrupadas segundo estádios desenvolvimento germinativo.

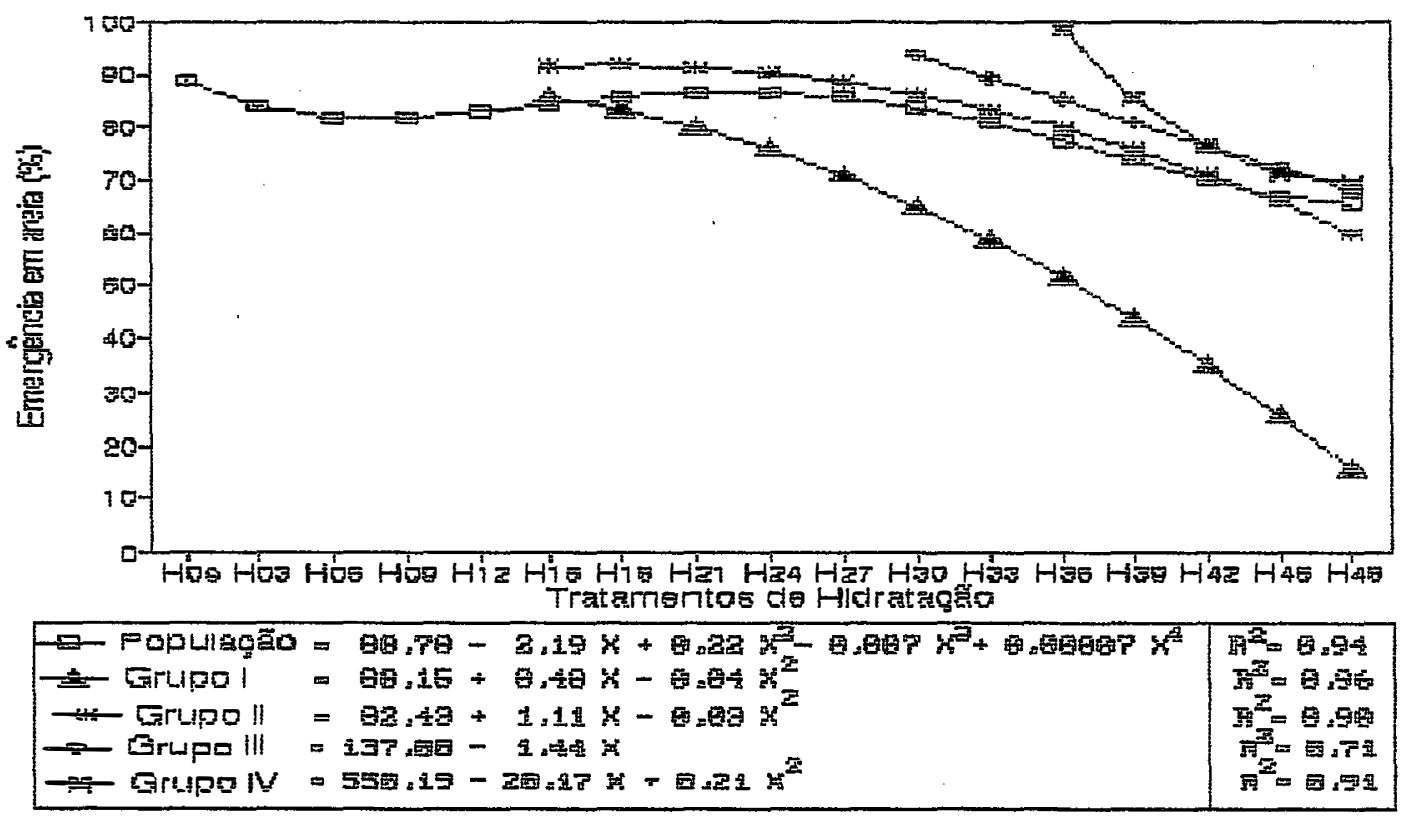

Figura 15. Estudo 2. Emergência em areia: curvas de regressão polinomial para os efeitos dos tratamentos de hiơratação e secagem, em sementes de trigo (cv. Batuíra) agrupadas segundo estádios de desenvolvimento germinativo. 


\subsubsection{Aceleração e sincronismo da germinação}

Os dados obtidos nos testes de primeira contagem e de velocidade de emergência (Tab.14 e 15; Fig. 16 e 17), revelaram o mesmo comportamento observado, nos testes de germinação e de emergência em areia, para os grupos I e II. A velocidade de emergência das sementes que apresentavam o início da emissão radicular (Grupo II I), no período de seu surgimento ( 30 horas de hidratação), indicou resultados significativamente inferiores aos da população total e do grupo II, igualando-se aos do grupo I. O grupo IV apresentou resultados absolutos ligeiramente superiores aos da população total e aos dos demais grupos, principalmente, quando obtido das hidratações de 48 horas.

Nos dois testes, o grupo I apresentou resultados significativamente inferiores aos dos demais grupos em periodos de hidratação superiores a 21 horas para velocidade de emergência e 27 horas para primeira contagem. O fato sugere que as sementes, que nesses periodos de hidratação, permanecem sem nenhum sinal visível de germinação representem as não viáveis, ou as de menor nível de vigor dentro da população sendo, neste caso, mais sensiveis à desidratação subsequente. 
Tabela 14. Estudo 2. Primeira contagem de germinação: valores médios (\%) obtidos pela população total de sementes e pelos grupos formados, en função do estádio de desenvolvimento germinativo atingido, após os tratamentos de hidratação (variáveis de 0 a 48 horas) que precederam a secagern.

\begin{tabular}{|c|c|c|c|c|c|c|c|c|c|}
\hline \multirow{2}{*}{$\begin{array}{l}\text { Trat amentos } \\
\text { de } \\
\text { Hidrat ação }\end{array}$} & \multicolumn{2}{|l|}{ População } & \multicolumn{6}{|c|}{ Grupos de desenvolvimento } & \multirow{2}{*}{$\begin{array}{l}C y \\
(y)\end{array}$} \\
\hline & Total & & GI & & G II & & G III & G IV & \\
\hline HOS & 80.16 & a & - & & - & & - & - & $\sim$ \\
\hline $\mathrm{HO}$ & 78.03 & $a b$ & - & & - & & - & - & - \\
\hline Ho6 & 79.66 & $a b$ & - & & - & & - & - & - \\
\hline$H 09$ & 78.37 & $a b$ & - & & - & & - & - & - \\
\hline$H 12$ & 77.72 & $a b$ & - & & - & & - & - & - \\
\hline $\mathrm{H} 15$ & $79.12^{B}$ & $a b$ & $79.35^{B}$ & a & $92.14^{\mathrm{A}}$ & a & - & - & 11.3 \\
\hline H18 & $79.39 \mathrm{~A}$ & $a b$ & $78.74^{A}$ & $a b$ & $76.30^{A}$ & abcd & - & - & 11.3 \\
\hline H21 & $82.84^{A}$ & a & $79.29 \mathrm{~A}$ & a & $88.01^{A}$ & $a b c$ & - & - & 11.3 \\
\hline H24 & $79.66^{\mathrm{A}}$ & $a b$ & $78.10^{A}$ & $a b$ & $82.04^{A}$ & abcd & - & - & 11.3. \\
\hline H27 & $83.78^{A}$ & $a$ & $79.64 \mathrm{~A}$ & a & $85.77^{A}$ & $a b c$ & - & - & 11.3 \\
\hline H3O & $82.55^{\mathrm{A}}$ & $a$ & $54.03^{B}$ & bc & $88.21^{A}$ & $a b$ & $50.00^{8} \mathrm{bc}$ & - & 15.4 \\
\hline H33 & $72.27^{\mathrm{A}}$ & $a b c$ & $33.42^{B}$ & cd & $77.51 \mathrm{~A}$ & $a b c d$ & $76.09^{A}$ a & - & 15.4 \\
\hline$H 36$ & $65.20 \mathrm{~A}$ & abcd & $26.42^{B}$ & de & $71.43^{\mathrm{A}}$ & bed & $62.07^{\mathrm{A}} \mathrm{ab}$ & $63.76^{\mathrm{A}} \mathrm{a}$ & 14.4 \\
\hline$H 39$ & $56.03^{A}$ & bcd & $34.92^{B}$ & cod & $65.82 \mathrm{~A}$ & cd & $49.66^{A B}$ bc & $52.01^{A B} \mathrm{ab}$ & 14.4 \\
\hline $\mathrm{H} 42$ & $52.51^{A}$ & bod & $13.11^{B}$ & de & $59.75 \mathrm{~A}$ & de & $57.60^{A}$ abc & $51.67^{A} \mathrm{~b}$ & 14.4 \\
\hline H45 & $43.65 \mathrm{AB}$ & $d$ & $10.74^{C}$ & e & $35.41^{B}$ & ef & $37.90^{A B} \mathrm{C}$ & $54.54^{\mathrm{A}} \mathrm{b}$ & 14.4 \\
\hline H48 & $47.83^{\mathrm{AB}}$ & cd & $0.00^{C}$ & $f$ & $32.89^{B}$ & $f$ & $44.25^{\mathrm{AB}} \mathrm{bc}$ & $54.35^{A} \mathrm{~b}$ & 14.4 \\
\hline CV $(x)=$ & 13.8 & & 16.2 & & 16.2 & & 15.4 & 14.4 & \\
\hline
\end{tabular}

Médias seguidas pela mesma letra maiúscula na linha e letra minúscula na coluna não diferem entre si pelo Teste de Tukey (5\% de probabilidade). 
Tabela 15. Estudo 2. Indices de velocidade de emergência: valores médios obtidos pela população total de sementes e pelos grupos formados, em função dos estádios de desenvolvimento germinativo atingido, após os tratamentos de hidratação (variáveis de 0 a 48 horas) que precederam a secagem.

\begin{tabular}{|c|c|c|c|c|c|c|c|c|c|c|c|}
\hline \multirow{2}{*}{$\begin{array}{l}\text { Tratamentos } \\
\text { de } \\
\text { Hidratação }\end{array}$} & \multirow{2}{*}{\multicolumn{2}{|c|}{$\begin{array}{l}\text { População } \\
\text { Total }\end{array}$}} & \multicolumn{7}{|c|}{ Grupos de desenvolvimento } & & \multirow{2}{*}{$\begin{array}{l}C V \\
(y)\end{array}$} \\
\hline & & & GI & & G II & & GIII & & G IV & & \\
\hline HOS & 26.09 & abcd & - & & - & & - & & - & & - \\
\hline HO3 & 24.01 & code & - & & - & & - & & - & & - \\
\hline HOG & 23.42 & cde & - & & - & & - & & - & & - \\
\hline HO9 & 24.00 & cde & - & & - & & - & & - & & - \\
\hline H12 & 24.60 & bede & - & & - & & - & & - & & - \\
\hline H15 & $25.27^{B}$ & $a b c d$ & $25.39^{B}$ & $a b$ & $32.67 \mathrm{~A}$ & a & - & & - & & 14.2 \\
\hline H18 & $27.11^{A}$ & $a b c$ & $26.85^{A}$ & a & $26.16^{A}$ & $b$ & - & & - & & 14.2 \\
\hline H21 & $26.43^{A}$ & $a b c$ & $25.97^{A}$ & $a b$ & $29.31^{A}$ & $a b$ & - & & - & & 14.2 \\
\hline H24 & $28.19^{A}$ & $a b$ & $23.19^{B}$ & $a b c$ & $29.94 \mathrm{~A}$ & $a b$ & - & & - & & 14.2 \\
\hline H27 & $28.73^{A}$ & $a$ & $22.59^{B}$ & $a b c$ & $30.07^{A}$ & $a b$ & - & & - & & 14.2 \\
\hline H3O & $26.83^{A}$ & $a b c$ & $19.80^{B}$ & bcd & $28.74^{A}$ & $a b$ & $21.57^{B}$ & a & - & & 14.9 \\
\hline H33 & $25.68 \mathrm{AB}$ & abcd & $14.82^{C}$ & de & $28.16^{A}$ & $a b$ & $21.99^{B}$ & a & - & & 14.9 \\
\hline H36 & $26.74^{A}$ & $a b c$ & $20.50^{B}$ & abcd & $27.96^{\mathrm{A}}$ & $a b$ & $24.77^{A}$ & $a$ & $26.00^{A}$ & $a$ & 15.4 \\
\hline H39 & $24.83^{A}$ & bcde & $17.79^{B}$ & cde & $26.09 A$ & bc & $25.94 \mathrm{~A}$ & a & $27.05^{A}$ & $a$ & 15.4 \\
\hline H42 & $22.65^{\mathrm{A}}$ & def & $13.12^{B}$ & $e$ & $24.88^{A}$ & bed & $23.48^{\mathrm{A}}$ & a & $24.62^{A}$ & $a b$ & 15.4 \\
\hline H45 & $19.12^{\mathrm{A}}$ & $f$ & $4.64^{B}$ & $f$ & $19.78^{A}$ & cd & $20.88^{A}$ & a & $19.83^{A}$ & $b$ & 15.4 \\
\hline H48 & $21.18^{A}$ & ef & $3.93^{B}$ & $f$ & $19.38 \mathrm{~A}$ & $d$ & $22.70^{\mathrm{A}}$ & $a$ & $22.09 A$ & $a b$ & 15.4 \\
\hline $\operatorname{CV}(y)=$ & 15.2 & & 14.7 & & 14.7 & & 14.9 & & 16.2 & & \\
\hline
\end{tabular}

Médias seguidas pela mesma letra maiúscula na linha e letra minúscula na coluna não diferem entre si pelo Teste de Tukey (5\% de probabilidade). 


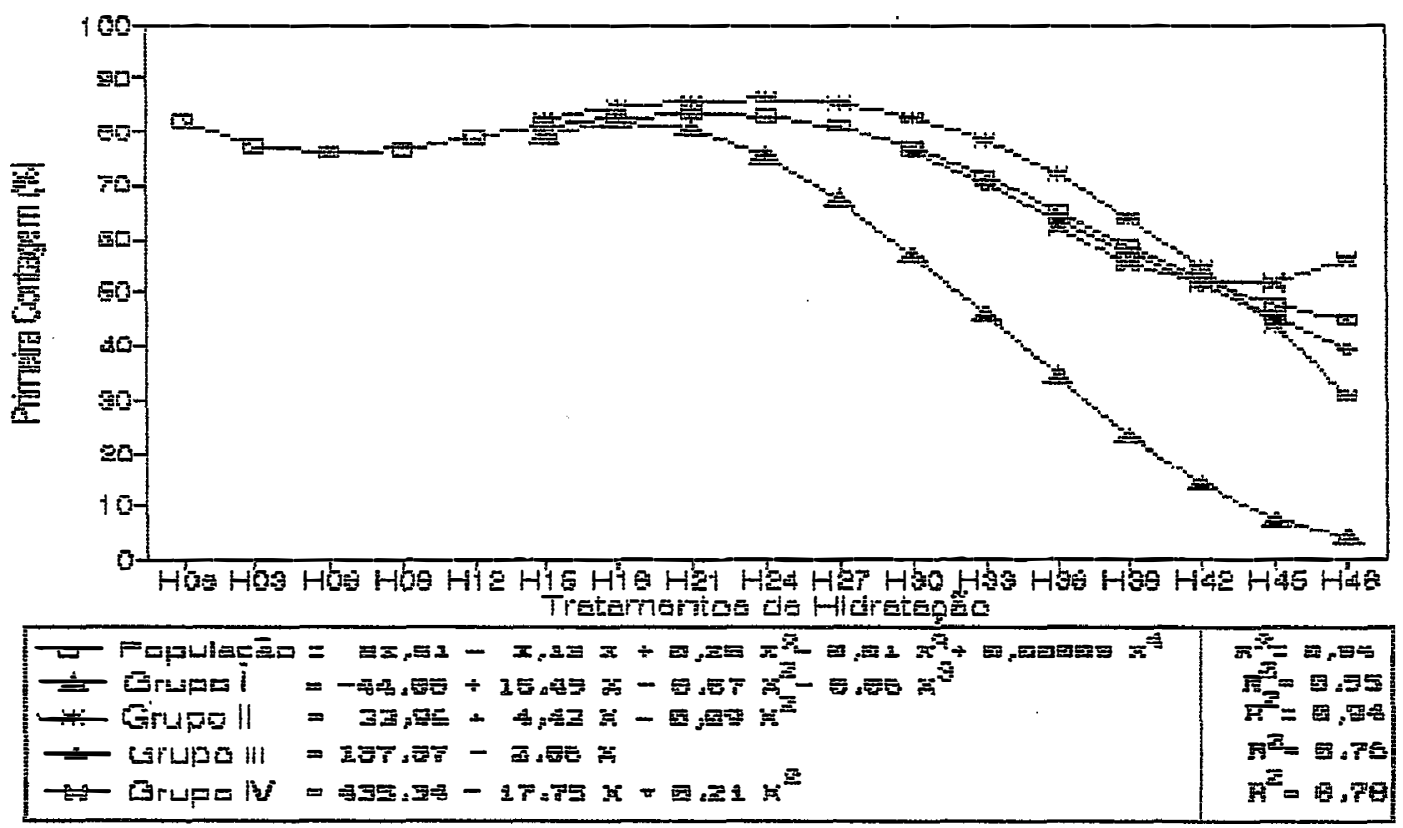

Figura 16. Estudo 2. Primeira contagem de germinação: curvas de regressão polinomial para os efeitos dos tratamentos de hidratação e secagem, em sementes de trigo ( $c V$. Batuira) agrupadas segundo estádios de desenvolvimento germinativo.

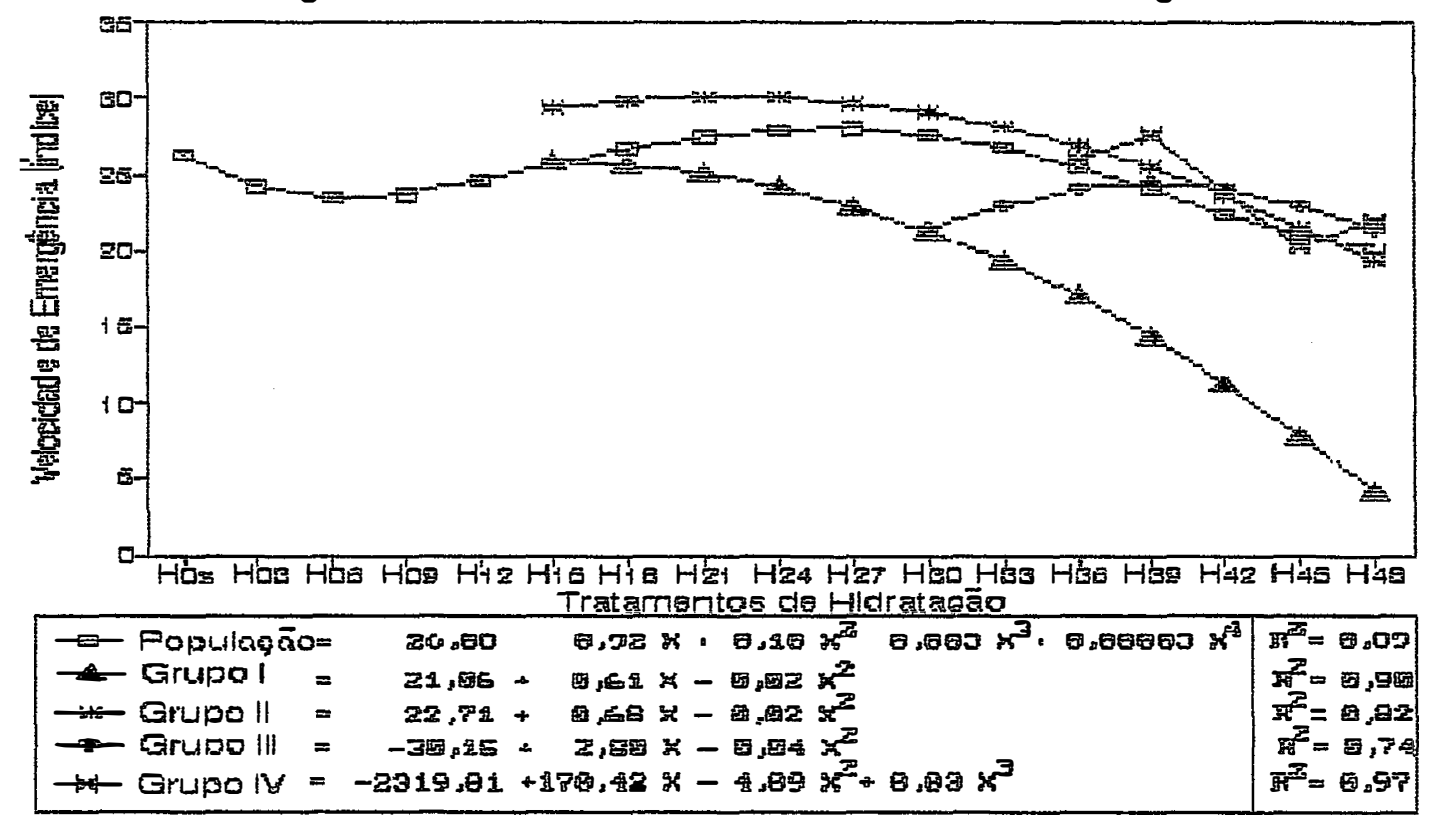

Figura 17. Estudo 2. Indice de velocidade de emergência em. areia: curvas de regressão polinomial para os efeitos dos tratamentos de hidratação e secagem, em sementes de trigo ( $C V$. Batuíra) agrupadas segundo estádios de desenvolvimento germinativo. 


\subsubsection{Taxa de crescimento de plântula}

Os resultados da avaliação do comprimento de plântulas (Tabela 16; Figura 18) mostram que as sementes, representantes dos grupos I e I I (fase anterior à da emissão da raíz primária), tiveram um desempenho superior, na maioria dos periodos de hidratação, sendo e similar aos dos grupos III e IV nos periodos de 33 e 36 horas, respectivamente, e nos períodos máximos ( 45 e 48 horas).

Analizando os resultados obtidos por um único grupo, em função do periodo de hidratação de sua obtenção, verifica-se que a desidratação produz efeitos negativos nas sementes do grupo I, obtidos nos periodos superiores a 39 horas e do grupo II, nos periodos superiores a 36 horas de hidratação. As cariópses com emissão radicular (grupos II I e IV), não foram prejudicadas pela à desidratação, apenas nos períodos de seu surgimento quando, possivelmente, representavam os individuos mais vigorosos.

Durante a avaliação do comprimento das plântulas, foi possivel observar no grupo IV que, especialmente nos estádios mais avançados de desenvolvimento ( $E$ e F), a desidratação havia provocado a morte das raízes; contudo, com a reidratação, houve a emissão e o crescimento de novas raizes a partir de iniciações secundárias. O epicotilo, entretanto, não foi 
afetado pela desidratação, mesmo quando houve crescimento durante a hidratação prévia. As follhas primárias permaneceram vivas após a desidratação, o que foi detectado através da coloração dos tecidos com sal de tetrazólio. Contudo, nos casos extremos de desenvolvimento do epicótilo (> 5mm), a desidratação provocou a morte do coleoptilo, o que dificultaria a condução e a proteção da folha primária durante a emergência, constituindo-se uma causa de classificação das plântulas como anormais.

Nesta avaliação, as medições de plântulas são realizadas considerando o maior comprimento das raízes; com a desidratação e morte da raíz primária, o desenvolvimento radicular prosseguindo a partir de iniciações secundárias. Assim sendo, é possível supor que, - crescimento das raizes seminais secundárias tenha ocorrido a velocidades inferiores às da raíz primária e, dessa forma, tenham reduzido os valores de comprimento, nos grupos de desenvolvimento mais avançado. 
Tabela 16. Estudo 2. Comprimento de plântulas: valores médios (cm/pl) obtidos pela população total de sementes e pelos grupos formados, em função do estádio de desenvolvimento germinativo atingido, após os tratamentos de hidratação (variáveis de 0 a 48) que precederan a secagem.

\begin{tabular}{|c|c|c|c|c|c|c|c|c|c|c|c|}
\hline \multirow{2}{*}{$\begin{array}{l}\text { Trat amentos } \\
\text { de } \\
\text { Hidrat ação }\end{array}$} & \multirow{2}{*}{\multicolumn{2}{|c|}{$\begin{array}{c}\text { População } \\
\text { Total }\end{array}$}} & \multicolumn{7}{|c|}{ Grupos de desenvolvimento } & & \multirow{2}{*}{$\begin{array}{l}\text { CV } \\
(z)\end{array}$} \\
\hline & & & GI & & G II & & G III & & G IV & & \\
\hline HOS & 22.03 & a & - & & - & & - & & - & & - \\
\hline HO3 & 20.76 & a & - & & - & & - & & - & & - \\
\hline HOG & 20.21 & $a b$ & - & & - & & - & & - & & - \\
\hline HOg & 22.28 & $a$ & - & & - & & - & & - & & - \\
\hline$H 12$ & 21.97 & a & - & & - & & - & & - & & - \\
\hline$H 15$ & $22.28 \mathrm{~A}$ & $a$ & $22.14^{\mathrm{A}}$ & $a b$ & $22.85^{\mathrm{A}}$ & a & - & & - & & 12.0 \\
\hline H18 & $22.19 \mathrm{~A}$ & $a$ & $22.08^{A}$ & $a b$ & $23.32^{A}$ & $a$ & - & & - & & 12.0 \\
\hline H21 & $22.59 \mathrm{~A}$ & $a$ & $22.13^{A}$ & $a b$ & $22.47^{\mathrm{A}}$ & $a$ & - & & - & & 12.0 \\
\hline H24 & $23.66^{\mathrm{A}}$ & $a$ & $23.58^{A}$ & a & $23.52^{\mathrm{A}}$ & $a$ & - & & - & & 12.0 \\
\hline H27 & $22.70^{\mathrm{A}}$ & a & $20.57^{A}$ & $a b c$ & $23.49^{\mathrm{A}}$ & a & - & & - & & 12.0 \\
\hline H3O & $22.51^{\mathrm{A}}$ & a & $22.16^{\mathrm{A}}$ & $a b$ & $23.38^{A}$ & $a$ & $16.18^{B}$ & $a$ & - & & 14.9 \\
\hline H33 & $21.84^{\mathrm{A}}$ & a & $19.68 \mathrm{~A}$ & $a b c$ & $21.92 \mathrm{~A}$ & a & $23.34 \mathrm{~A}$ & b & - & & 14.9 \\
\hline H36 & $20.70^{A B}$ & $B$ a & $20.10^{A B}$ & $a b c$ & $21.54^{A}$ & $a b$ & $16.43^{B}$ & b & $20.89^{A B}$ & a & 17.0 \\
\hline H39 & $16.23^{B}$ & $b c$ & $24.61 \mathrm{~A}$ & a & $16.31^{B}$ & $b c$ & $17.52^{B}$ & b & $16.25^{B}$ & $a b$ & 17.0 \\
\hline H42 & $16.12^{B}$ & c & $16.30^{A B}$ & $c$ & $20.96^{A}$ & $a b$ & $13.62^{B}$ & b & $14.85^{B}$ & b & 17.0 \\
\hline H45 & $14.98 \mathrm{~A}$ & c & $17.13^{A}$ & $b c$ & $12.78^{A}$ & c & $15.52^{\mathrm{A}}$ & b & $14.49 \mathrm{~A}$ & b & 17.0 \\
\hline$H 48$ & $14.33^{\mathrm{A}}$ & c & $15.30^{A}$ & $c$ & $15.25^{A}$ & c & $17.23^{A}$ & b & $13.37^{\mathrm{A}}$ & b & 17.0 \\
\hline $\operatorname{CV}(z)=$ & 9.8 & & 13.6 & & 13.6 & & 15.9 & & 17.0 & & \\
\hline
\end{tabular}

Médias seguidas pela mesma letra maiúscula na linha e letra minúscula na coluna não diferem entre si pelo Teste de Tukey (5\% de probabilidade). 


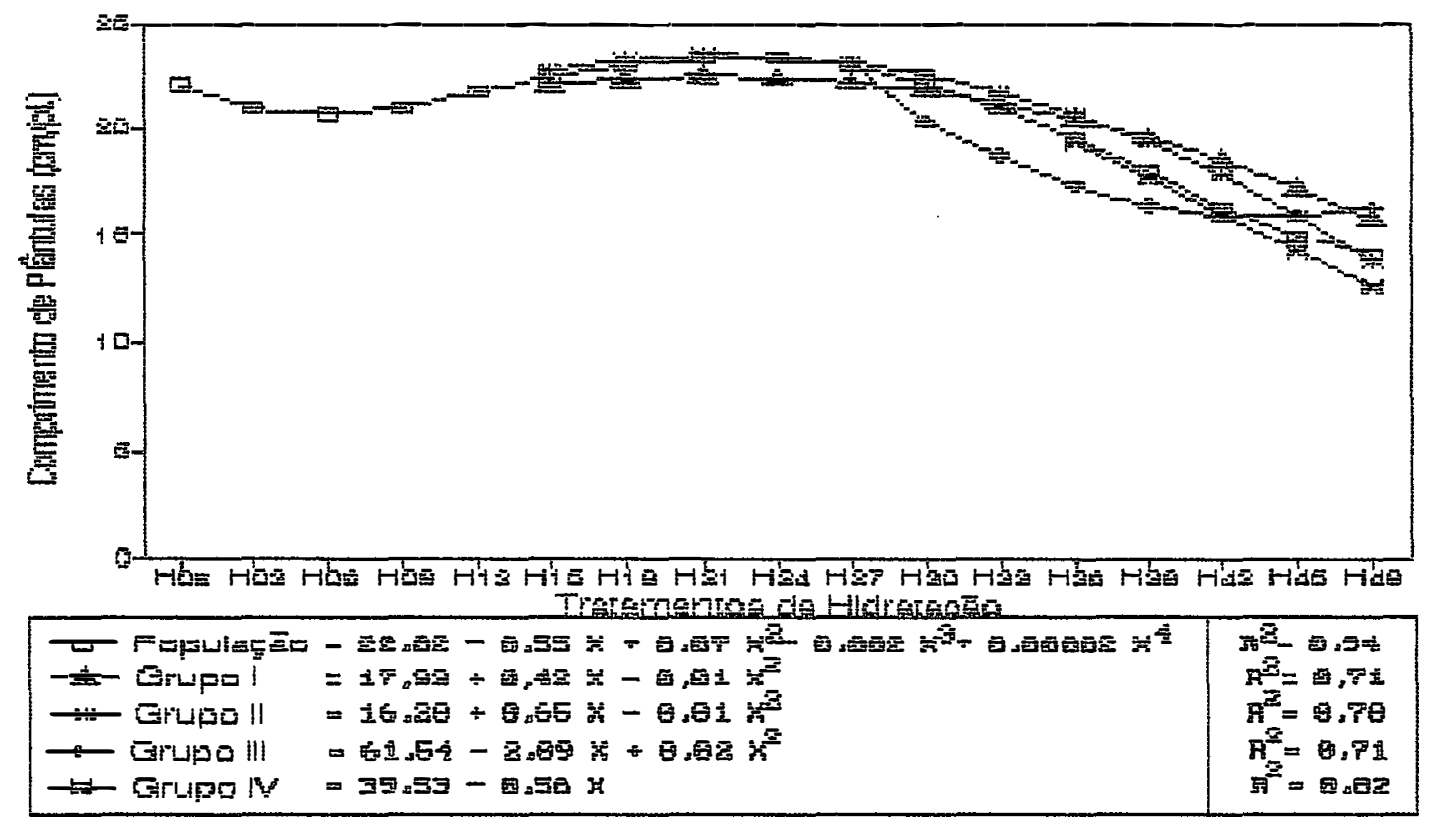

Figura 18. Estudo 2. Comprimento de plântulas: curvas de regressão polinomial para os efeitos dos tratamentos de hidratação e secagem, em sementes de trigo (cV. Batuíra) agrupadas segundo estádios de desenvolvimento germinativo.

4.2.2.4. Permeabilidade das membranas celulares

os dados do teste de condutividade elétrica, mostrados na Tabela 17 e na Figura 19, revelam aumentos, na lixiviação de eletrólitos, devidos ao avanço no desenvolvimento das sementes no processo de germinação e à ampliação dos períodos de hidratação.

$$
\text { Com relação as sementes que não }
$$
apresentavam sinais visiveis de crescimento embrionário (grupo I), observa-se uma tendência inicial decrescente na taxa de liberação de eletrólitos ao meio de embebição, tornando-se mínima nas sementes obtidas do período de 27 
horas de hidratação e voltando a crescer nas hidratações dos periodos superiores. As sementes que se mantiveram neste grupo, nos períodos superiores à 33 horas de hidratação, mostraram aumentos significativos na condutividade elétrica do meio de embebição, indicando a existência de individuos com maior deterioração das membranas celulares. Com o decréscimo daa frequência de sementes do grupo I na população, esta passou a apresentar valores de condutividade significativamente superiores, a partir de 21 horas de hidratação, quando os representantes do grupo I passaram a constituir a maioria.

Após a ruptura do pericarpo (grupo I I), como seria esperado, ocorreu elevação na quantidade de eletrólitos liberados ao meio de embebição. Contudo, houve decréscimo significativo na taxa de lixiviação, até um mínimo, nos individuos do grupo I I surgidos no periodo de 21 horas de hidratação. Os acréscimos nos valores de condutividade do grupo I I ocorrerem menos acentuadamente do que os das sementes do grupo I; com isso, houve uma tendência de aproximação, entre os valores de condutividade, dos dois grupos, nos periodos mais longos de hidrat ação. Comparando os resultados obtidos pelos dois grupos, em períodos de hidratação distintos, observa-se que, apesar de apresentarem o pericarpo rompido, as sementes do grupo II, podem liberar eletrólitos em quantidade equivalente ou inferior à do grupo I. 
Tabela 17. Estudo 2. Condutividade elétrica: dados médios (Lmhos $/ \mathrm{cm} / \mathrm{g}$ ) obtidos pela população total de sementes e pelos grupos formados, em função do estádio de desenvolvimento germinativo atingido, após os tratamentos de hidratação (variáveis de 0 a 48 horas), que precederam a secagem.

Trat a ne n t os

\begin{tabular}{|c|c|c|c|c|c|c|c|c|}
\hline \multirow{2}{*}{$\begin{array}{l}\text { Tratamentos } \\
\text { de } \\
\text { Hidratação }\end{array}$} & \multirow{2}{*}{$\begin{array}{c}\text { Populaçãa } \\
\text { Total }\end{array}$} & \multicolumn{6}{|c|}{ Grupos de desenvolvimento } & \multirow{2}{*}{$\begin{array}{l}C V \\
(\%)\end{array}$} \\
\hline & & GI & & G II & & G III & G IV & \\
\hline HOS & $23.20 \mathrm{ab}$ & - & & - & & - & - & - \\
\hline HO3 & 22.96 & - & & - & & - & - & - \\
\hline HOG & 18.76 & - & & - & & - & - & - \\
\hline HOS & $18.52 \quad a$ & - & & - & & - & - & - \\
\hline$H 12$ & $21.40 \quad a$ & - & & - & & - & - & - \\
\hline H15 & $17.66^{\mathrm{A}}$ & $16.89^{A}$ & $a b$ & $39.48^{B}$ & def & - & - & 12.7 \\
\hline H18 & $21.11^{\mathrm{A}}$ & $18.77^{\mathrm{A}}$ & $a b$ & $31.43^{B}$ & $a b c$ & - & - & 12.7 \\
\hline H21 & $18.45^{A B}$ & $14.53^{\mathrm{A}}$ & $a$ & $24.89^{B}$ & $a$ & - & - & 12.7 \\
\hline H24 & $20.98^{B}$ & $12.43^{A}$ & $a$ & $28.55^{\mathrm{C}}$ & $a b$ & - & - & 12.7 \\
\hline H27 & $22.70^{\mathrm{B}}$ & $11.91 \mathrm{~A}$ & $a$ & $30.60^{C}$ & $a b c$ & - & - & 12.7 \\
\hline H30 & $28.59^{B}$ & $15.26 \mathrm{~A}$ & $a$ & $34.40^{B}$ & $b c d$ & $34.40^{\mathrm{B}} \mathrm{a}$ & - & 12.0 \\
\hline H33 & $34.33^{B}$ & $15.31^{\mathrm{A}}$ & $a$ & $37.69 \mathrm{BC}$ & cde & $43.37^{C}$ b & - & 12.0 \\
\hline H36 & $42.71^{\mathrm{B}}$ & $24.07^{\mathrm{A}}$ & $b$ & $43.06^{B}$ & ef & $48.69 \mathrm{BC}$ bc & $51.41^{\mathrm{C}} \mathrm{a}$ & 10.8 \\
\hline H39 & $42.78^{B}$ & $23.38 \mathrm{~A}$ & $b$ & $41.17^{B}$ & def & $52.07^{\mathrm{C}}$ cd & $55.86^{C} \mathrm{a}$ & 10.8 \\
\hline H42 & $48.69 \mathrm{BC}$ & $32.26 \mathrm{~A}$ & $c$ & $45.15^{B}$ & efg & $54.40^{c}$ cd & $52.30^{\mathrm{BC}} \mathrm{a}$ & 10.8 \\
\hline H45 & $54.24 \mathrm{BC}$ & $38.23 \mathrm{~A}$ & cd & $47.30^{B}$ & fg & $58.49^{\mathrm{C}} \mathrm{de}$ & $58.66^{\mathrm{C}} \mathrm{a}$ & 10.8 \\
\hline H48 & $65.17^{C}$ & $40.86^{A}$ & $d$ & $52.40^{B}$ & $g$ & $63.25^{\mathrm{C}} \mathrm{e}$ & $70.22^{C} b$ & 10.8 \\
\hline $\operatorname{CV}(\%)=$ & 9.9 & 13.9 & & 13.9 & & 12.0 & 10.8 & \\
\hline
\end{tabular}

Médias seguidas pela mesma letra maiúscula na linha e letra minúscula na coluna não diferem entre si pelo Teste de Tukey (5\% de probabilidade). 


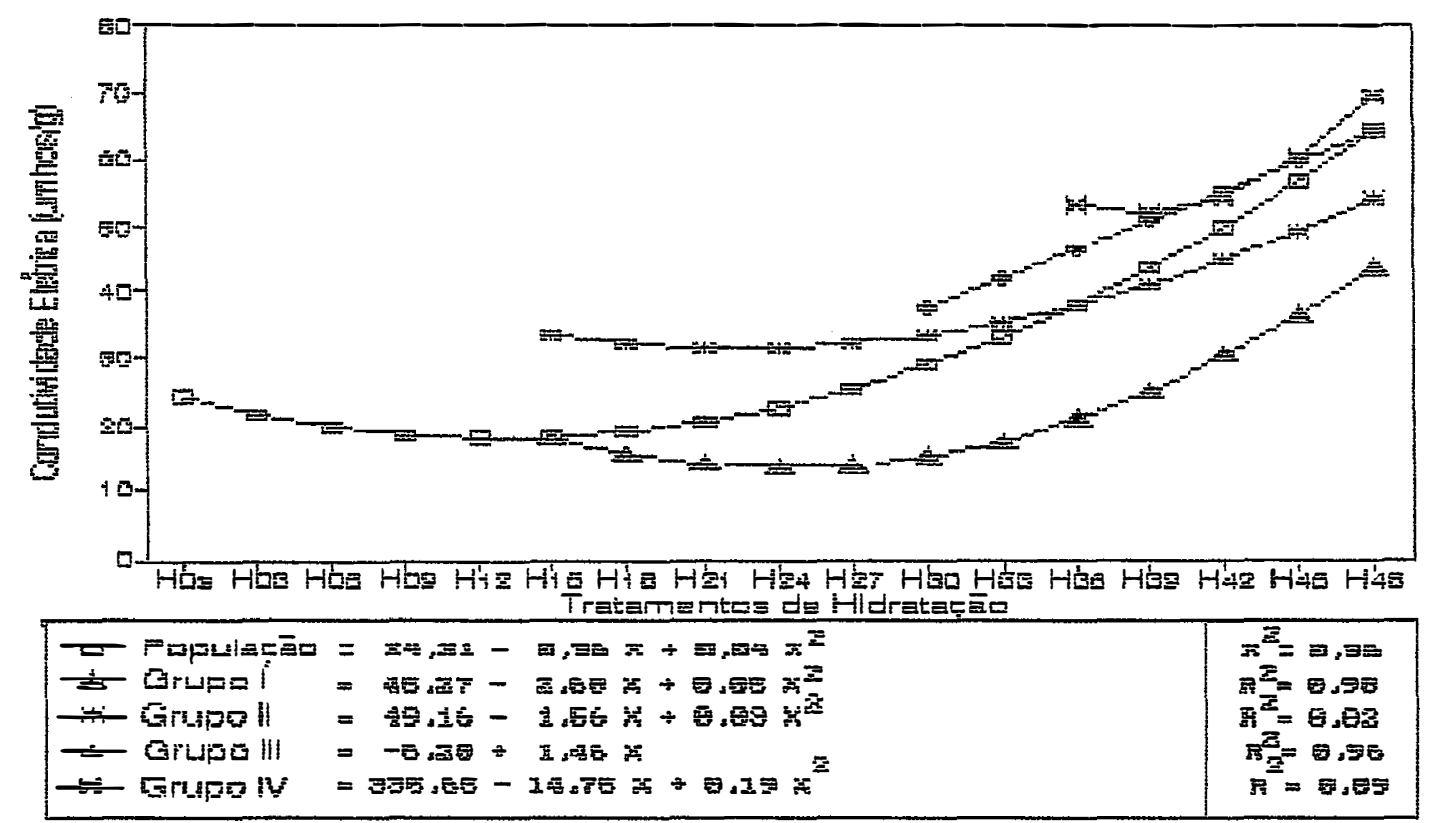

Figura.19. Estudo 2. Condutividade elétrica do meio de embebição: curvas de regressão polinomial para os efeitos dos tratamentos de hidratação e secagem, em sementes de trigo (cv. Batuíra) agrupadas segundo estádios de desenvolvimento.

As sementes do grupo III apresentaram crescimento linear, na liberação de eletrólitos ao meio, à medida em que era ampliado o período de hidratação; partindo de valores iguais aos do grupo II, tornaram-se superiores nos períodos de hidrat ação maiores do que 36 horas. A comparação entre períodos diferentes mostra que os indivíduos do grupo III, obtidos nos períodos próximos ao do seu surgimento, podem apresentar valores de condutividade equivalentes ou inferiores aos apresentados pelas sementes de grupos menos avançados. outro fato observado é o de que as sementes, que atingem este estádio mais precocemente, são as que apresentam menor degradação 
das membranas, reforçando as observações efetuadas nos testes anteriores com respeito ao desempenho das sementes. As sementes do grupo IV mostraram resultados de condutividade elétrica similares aos das sementes do grupo III. Contudo, a variação inicial, em função do período de hidratação, foi pouco acentuada e permaneceu com valores quase constantes até o periodo de 42 horas de hidratação. Isto fez com que os resultados do grupo IV se aproximassem dos obtidos pelo grupo III e não diferissem significativamente, no periodo de 42 horas de hidratação, dos resultados do grupo II.

O resultado mais elevado obtido no teste de condutividade, refletindo a maior perda de eletrólitos para o meio de embebição, foi obtido nos individuos do grupo IV presentes no período de hidratação de 48 horas. Assim, a perda de eletrólitos ao meio de embebição aumenta com a ampliação do período de hidratação prévia e com o avanço do estádio de desenvolvimento em que é realizada a secagem.

Os resultados obtidos no teste de condutividade elétrica, para a população total, indicam que a ruptura do pericarpo das sementes, apenas, não eleva a perda de eletrólitos ao meio de embebição; contudo, a tendência de elevação nos valores se expressa, de forma mais acentuada, quando as sementes são submetidas à secagem após o início da emissão radicular. 
113.

4.3.3. Estudo 2. Considerações gerais

Os dados obtidos, nos testes de desempenho fisiológico, divergem das afirmações de vários autores (MAY et a1., 1962; HENCKEL, 1964; SALIN \& TOOD, 1968; DELTOUR \& JAQMARD, 1974; HEYDECKER, 1973/74; BEWLEY \& BLACK, 1978; HEGARTY, 1978; MANDAL \& BASU, 1987a; LABOURIAU, 1983; BEWLEY \& BLACK, 1985; BRADFORD, 1986) que consideram a emissão radicular como o estádio limite, dentro do processo de germinação a partir do qual a semente, perde a tolerância à desidratação. Os dados deste estudo mostram que não foi o estádio de desenvolvimento, de forma isolada, o fator determinante da perda de resistência à desidratação. A dessecação das sementes, nos estádios mais avançados da germinação, provocou a morte das raizes seminais primárias; contudo, com a reidratação, houve a retomada do crescimento a partir de iniciações secundárias, em processo similar ao observado por CARCELAR \& SORIANO (1972) e SEN \& OSBORNE (1974).

Por outro lado, os resultados sugerem que as sementes que atingiram um estádio de desenvolvimento, mais rapidamente do que as demais, correspondem aos individuos mais vigorosos da população e, portanto, os que apresentam maior capacidade de resistir à desidratação subsequente, concordando com as afirmações de ABDUL- BAKI \& ANDERSON (1972), e de HEGARTY (1977a). 


\section{CONCLUSÕES}

A análise dos dados e a interpretação dos resultados, considerando hidratações de sementes trigo com água destilada e sob temperatura constante de $20^{\circ} \mathrm{C}$, permitiram as seguintes conclusões:

- A sensibilidade à desidratação se manifesta quando a concentração de água nas amostras de sementes de trigo atinge niveis superiores a $42 \%$, o que ocorreu a partir de 30 horas do início da hidratação. - A emissão da raíz primária, por si só, não representa um referencial adequado para a definição do momento, a partir do qual, as sementes tornam-se sensiveis à desidratação. Embora a secagem conduza à morte da raíz primária, com a reidratação, o desenvolvimento radicular é retomado, a partir de iniciações secundárias.

- A tolerância à desidratação, durante o processo de germinação, varia com o cultivar, com o estado fisiológico das sementes, com o nível de hidratação atingido, e com o parâmetro fisiológico avaliado.

- As sementes que, em uma amostra submetida a hidratação, atingem estádios mais avançados de desenvolvimento, apresentam melhor desempenho e maior 
115.

tolerância à desidratação.

- Os melhores resultados, nos aspectos

fisiológico e sanitário, foram obtidos nos tratamentos em que, durante a embebição, as amostras de sementes atingiram teores de água entre 34 e $42 \%$, correspondendo aos periodos de hidratação, anteriores à secagem, situados entre 15 e 30 horas. 


\section{REFERÊNCIAS BIBLIOGRÁFICAS}

A-As-SAQUI, M. \& CORLETO, A. Effect of presowing hardening on seedling emergence of four forage species. Seed Science and Technology, Wageningen, 6(3): 701-9, 1978.

ABDUL-BAKI, A. A. \& ANDERSON, J.D. Physiological and biochemical deterioration of seeds In: KOZLOWSKI, T.T., ed. Seed Biology, New York Academic Press, 1972, v.2, p. 283-315.

ABDUL-BAKI, A.A. \& BAKER, J.E. Are changes in cellular organelles or membranes related to vigor loss in seeds? Seeds Science and Technology, Wageningen, 1(1): 89-125. 1973.

AKALEHIYWOT, T. \& BEWLEY, J. D. The effects of dehydratation - rehydratation treatments on proteín syntesis in oat grains (Avena fatua cv. Harman) during germination. Plant Physiology, Rockville, Suppl.59, Abstracts 185,1977 . 
X ANDERSON, J.D. \& BAKER, J.E. Deterioration of seeds during Aging. Phytopathology, St. Paul, 73(2): 335-9, 1983.

ASSOCIATION OF OFFICIAL SEED ANALYSTS - AOSA. Seed vigor testing handbook. East Lansing, 1983. 88p (Contribution 32 ).

AUSTIN, R.B.; LONDGEN, P.C. \& HUTCHINSON, J. Some effects of "hardening" carrot seed. Annals of Botany, London, 33(125): 883-95, 1969 .

BASU, R.N. Physico-chemical control of seed deterioration. Seed Research, New Delhi, 4(1): 15-23, 1976.

BASU, R.N. \& RUDRAPAL, A. Post-harvest seed physiology and seed invigoration treatments. In: Golden Jubilee International Conference On Frontiers of Research in Agriculture. Proceedings of Indian Statistical Institute, RoY, S. K., ed, Calcuta, India, 1982 p. $374-97$.

BAUER, A. \& BLACK, A.L. Sprouting in intact mature spikes of hard red spring wheat. Agronomy Journal, Madison, 75(6): 1016-22, 1983 .

BERLYN, G.P. Seed germination and morphogenesis. In: KOZLOWISKI, T. T., ed. Seed Biology, Academic Press, New York, 1972, v. 2, p. 223-312. 
BERRIE, A.M.M. \& DRENNAN, D.S. The effect of hydratationdehydratation on seed germination. New Phytologist, London $70(1): 135-42.1971$.

BEWLEY, J. D \& BLACK, M. Development, germination and growth. In: Physiology and biochemistry of seeds in relation to germination. Springer-verlag, New York, $1978, v .1,307 p$

BEWLEY, J.D \& BLACK, M. Seeds: physiology of development and germination. New York, Plenum Press, 1985.367p.

BLACK, R. A. \& EL-HADI, F. M. Pressowing treatments of Acacia senegal seed: germination and growth. Tropical Agriculture, Trinidad e Tobago, 69(1): 15-20, 1992.

BLACKMAN, S.A.; WETTLAUFER, S.H.; OBENDORF, R.L.; LEOPOLD, A.C. Maturation proteins associated with desiccation tolerance in soybean. Plant Physiology, Rockville, $96(3): 868-74,1991$.

BLEAK, A. T. \& KELLER, W. Field emergence and growth of wheatgras from pretreated vs. nontreated seeds. Crop Science, Madison, 10(1): 85-7, 1970 .

BRADFORD, K. J. Manipulation of seed water relations via 
osmotic priming to improve germination under stress conditions. Hortscience, Alexandria, 21(5): 1105-1112, 1986.

BRANLAGE, W. J.; LEOPOLD, A. C. \& PARRISH, D。J.Chilling stress to soybeans during imbibition. Plant Physiology, Rockville, 61(4): 525-9, 1978 .

BRASIL, Ministério da Agricultura. Regras para análise de sementes. Brasília, LANARV/SNDA/MA, 1980.188 p.

BRIGGLE, L. W. Pre-harvest sprout damage in wheat in the United States. Cereal Researsh Communications, Szeged, Hungary, $8(1 / 2): 245-50,1980$.

BRYANT, J.A. Fisiologia da semente. São Paulo, Editora Pedagógica Universitária, 1989. 86 p. (Temas de biologia, 31)

BUCHVAROV, P. \& GANTCHEFF, T. Influence of accelerated and natural ageing on free radical levels in soybean seeds. Physiologia Plantarum, Copenhagen, 60(1): 53-6, 1984.

BURGASS, W.R. \& POWELL, A.A. Evidence for Repair Process in the Invigoration of Seeds by Hydration. Annals of Bot any, London, 53(5): 753-7, 1984 . 
BUTCHER, J. \& STENVERT, N. L. Conditioning studies on Australian wheat. III. The role of rater of water penetration into the wheat grain. Journal science of Food Agriculture, London, 24(12): 1077-84, 1973.

CAMPBELL, A. B. \& CZARNECK, E.M. Columbus hard red spring wheat. Canadian Journal of Plant Science, Ottawa, $61(1): 147-8,1981$.

CARCELLAR, M.S. \& SORIANO, A. Effects of treatments given to grain, on growth of wheat roots under drought conditions. Canadian Journal of Botany, Ottawa, 50(1): $105-8,1972$.

CASTOR, L. L. \& FREDERICKSEN, R. A. Seed molding of grain sorghum caused by Fusarium and Curvularia species. Proceedings of American Phytopathology Society, St. Pau1, 4: 151-5, 1977 .

CHATTERJE, B.N. \& SINGH, A.I. Barley production from seeds treated before sowing. Journal of Agriculture Science, Cambridge, 100(1): 235-49, 1983.

CHEN, D.; SARID, S. \& KATCHALSKI, E. The role of water stress in the inactivation of messenger RNA of germinating wheat embryos. Proceedings of Natural Academy Science, Wasington, 61: 1378-1383, 1968. 
CHEN, S. S.C. \& VARNER, J.E. Respiration an protein syntesis in dormant and after-ripened seeds of Avena fatua. Plant Physiology, Washington, 46(1): 108-12, 1970 .

CHEN, $Y_{0}$ \& BURRIS, J. S. Role of carbohydrates in desiccation tolerance and membrane behavior in maturing maize seed. Crop Science, Madison, 30(5): 971-5, 1990.

CHEN, Y. \& BURRIS, J.S. Desiccation tolerance in maturing maize seed: membrane phospholipid composition and thermal properties. Crop Science, Madison, 31(3): $766-77,1991$.

CHING, T.M. Metabolism of germinating seeds. In: KOZLOWISKI, T. T., ed., Seed biology, Academic Press, London, 1972, v. 2, p. 103-218.

CHING, T.M. Biochemical aspects of seed vigor. Seed Science and Technology, Wageningen, 1(1): 73-88, 1973.

CHING, T.M. \& FOOTE, W. H. Post-harvest dormancy in wheat varieties. Agronomy Journal, Madison, 53(3): 183-6, 1961.

XCHRISTENSEN, $C$. M. Loss of viability in storage: 
microflora. Seed Science and Technology, Wageningen, $1(3): 547-62,1973$.

CHRISTENSEN, C.M. \& KAUFMANN, H. H. Grain storage: the role of fungi in quality loss. Minneapolis. Univ. of Minesota Press, 1969. 153p.

CLARKE, J.M. Measurement of relative water uptake rates of wheat seeds using agar media. Canadian Journal of Plant Science, Ottawa, 60(3): 1035-8, 1980 .

CLARKE, J.M. \& DePAUW, R.M. Water imbibition rate of wheat kernels as affected by kernel color, wethather damage, and method of threshing. Canadian Journal of Plant Science, Ottawa, 69(1): 1-7, 1989.

COCKS, P.S. \& DONALL, C. M. The germination and establishment of two annual pasture grasses (Hordeum leporiun: Link and Lolium rigidum Gaug.). Australian Journal. of Agricultural Research, Melbourne, 24(1): $1-10,1973$

DALIANIS, C. D. Improving the emergence rate of two grass species. Seed Science and Technology, Zürich, 17(3): $463-70,1989$. 
DASGUPTA, J.; BEWLEY, J.D.\& YONG, E. C. Desiccationtolerant and desiccation - intolerant stages during development and germination of Phaseolus vulgaris seeds. Journal of Experimental Botany, Oxford, 33(131): $1045-57,1982$

DELL'AQUILA, A. \& TRITTO, V. Germination and biochemical activities in wheat seeds following delayed harvesting, ageing and osmotic priming. Seed science and Technnology, Zürich, 19(1): 73-82, 1991.

DELOUCHE, J.C. Precepts of seed storage. In: Short course Proceedings. Seed Technology Laboratory. Mississippi State University, 1973. p.97-122.

DELOUCHE, J.C. \& BASKIN, C.C. Accelerated aging techniques for predicting the relative storability of seed lots. Seed Science and Technology, Wageningen, 1(2): 427-52, 1973.

DELTOUR, R. \& JACQMARD, A. Relation between water stress and DNA synthesis during germination of Zea mays L. Annals of Botany, London, 38(155): 529-34, 1974.

DERERA, N. F. The audit of sprouting. Cereal Research Communications, Szeged/Hungary, 8(1): 15-22, 1980. 
DERERA, N. F. BHATT, G. M. \& MCMASTER, G.J. On the problem of pre - harvest sprouting of wheat. Euphytica, Wageningen, 26: 299-308, 1977 .

De ROBERTIS, E. D.P. \& De ROBERTIS JR, E. M。F。 Bases da Biologia Celular e Molecular, Rio de Janeiro, Ed. Guanabara.1981, 332p.

DEY (PATHAK), G。 \& BASU, R. N. Physiochemical control of radiation and ageing damage in mustard seed. Indian Journal of Experimental Biology, Calcutta, 23(2): $167 / 71,1985$.

DEY (PATHAK), G. \& MUKHERJEE, R. K. Invigoration of dry seeds with physiologically active chemicals in organic solvents. Seed Science and Technology, Zürich, 16(1): $145-53,1988$

DONI FILHO, L. Efeitos do condicionamento fisiológico no comportamento de sementes de feijão (Phaseolus vulgaris L.). Piracicaba, 1992. 108 p. (Doutorado - Escola Superior de Agricultura "Luiz de Queiroz" /USP)

XEDWARDS, M. Metabolism as a function of water potencial in air-dry seeds of charlok (Sinapis arvensis). Plant Physiology, Rockville, 58(2): 237-9, 1976. 
ELLIS, R. H. \& ROBERTS, E. H. Towards a rational basis for seed quality. in: seed production. HEBBLETHWAIKE, P.D., ed., pp. 605-35. Butterworth, London, 1980.

ELLIS, R. H. \& ROBERTS, E. H. Desiccation, rehydration, germination, imbibition injury and longevity of pea seeds (Pisum sativum). Seed Science and Technology, Zürich, 10(3): 501-8, 1982 .

ELIAS, S. \& COPELAND, L. O. The effect of preharvest sprouting on germination, storability and field performance of four winter wheat varieties grown in Michigan. The Newsletter of Association of Officials Seed Analists, Oklahoma City, 61(2): 14-5, 1987.

FREED, R. D.; EVERSON, E. H.; RINGLUND, K. \& GULLORD, $M$ 。 Seed coat color in wheat and relationship to seed dormancy at maturity. Cereal Research Communications, Szaged/Hungary, 4(1/2): 147-9, 1976 .

FUNDAÇÃO INSTITUTO AGRONOBMICO DO PARANÁ - IAPAR. Recomendações Técnicas para a cultura do Trigo no Estado do Paraná - 1991. Londrina, IAPAR. 1991. 138p. (Circular IAPAR, 66)

GOLDSWORTHY, A.; FIELDING, J.L.\& DOVER, M.B.J.'FTash 
imbibition': a method for the re-invigoration of aged wheat seed. Seed Science and Technology, Zürich, 10(1): $55-65,1982$.

GORDON, I. L. Selection against sprouting damage in wheat. III. Dormancy, germinative alpha-amylase, grain redness and flavanols Australian Journal of Agricultural Research, East Melbourne, 30(3): 387-402, 1979.

GORDON, I. L.; DERERA, N.F. \& BALAAM, L. N. Selection against sprouting damage in wheat. I. Germination of unthreshed grain, with a standard wetting procedure. Australian Journal of Agricultural Research, East Melbourne, 28(3): 583-96, 1977.

GRAMSHAW, D. \& STERN, W. R. Survival of annual ryegrass (Lolium rigidum Gaud.) in a seed germination in autumn. Australian Journal of Agricultural Researsh, East Melbourne 28(1): 81-91, 1977 .

GUSTA, L. V. \& CHEN, T. H. H. The physiology of water and temperature stress. In: HEYNE, E. G., ed., WHEAT AND WHEAT IMPROVEMENT, Madison, American Society of Agronomy, 1987. p. 115-50.

HABER, A. H. \& LUIPPOLD, H. J. Separation of mechanisms 
initiating cell division and cell expansion in lettuce germination. Plant Physiology, Ktztown, 35(2): 168-73, 1960 .

HAIGHT, J.C.\& GRABE, D. F. Wetting and drying treatments to improve the performance of orchard grass seeds. Proceedings of Association of Officials Seed Analists, Oklahoma City, 62: 135-48. 1972.

HALIN, A. H.; WASSOM, C.E.; MITCHEL, H.L. \& EDMUNDS, L. K. Supression of fungal growth by isolated trypsin inhibitors of corn grain. Journal of Agricultural Food Chemistry, Washington, 21(6): 1118-19, 1973.

HALLAN, N.D. Fine structure of viable and non-viable rye and others embrios. In: HEYDECKER, $w$, ed., seed Ecology, London, Butterworths, 1973, 578 p.

HALLOIN, J.M. Deterioration Resistance Mechanisms in Seeds. Symposium: Deterioration Mechanisms in Seeds. Phytopathology, St. Paul, 73(2): 335-9, 1983.

HANSON, A. D. The effects of imbibition drying treatments on wheat seeds. New Phytologist, London, 72(4): $1063-73,1973$ 
HARMAN, G. E. \& MATTICK, L. R. Association of lipid oxidation with seed ageing and death. Nature, London, $260(2): 323-4,1976$.

HARRINGTON, J.F. seed storage and longevity. In: KOZLOWSKI, T. T., ed., Seed Biology, New York, Academic Press, 1972, v. 2, p. 145-245.

HARRINGTON, J.F. Biochemical basis of seed longevity. Seed Science and Technology, Wageningen, 1(2): 453-61, 1973.

X Harrison, J. G. \& PERRY, D. A. Studies on the mechanism of barley seed deterioration. Annals of Applied Biology, London, 84(1): 57-62, 1976 .

HAYWARD, H. E. Estructura de las plantas utiles. Trad. O. Nuñes. Buenos Aires, Editorial ACME, 1953. 180 p.

HEGARTY, T.W. The possibility of increasing field establishment by seed hardening. Horticulture Research, Edinburgh, 10(1): 59-64, 1970 .

HEGARTY, T. W. seed and seedling susceptibility to phase moisture stress in soil. Journal of Experimental Botany, Oxford, 28 (104): 659-68, 1977a. 
HEGARTY, T.W. Seed activation and seed germination under moisture stress. New Phytologist, London, 78(3): $349-59,1977 b$.

HEGARTY, T. W. The physiology of seed hydratation and dehydratation, and the relation between water stress and the control of germination: a review. Plant, cell and Environment, New York, 1(1): 101-19, 1978.

HENCKEL, P. A. Physiology of plants under drought. Annual Review of Plant Physiology, Palo Alto, 15: 363-86, 1964.

HEYDECKER, W. Vigor. In: ROBERTS, E. H., ed., Viability of seeds, London, Chapman and Hal1, 1972, p. 209-52.

HEYDECKER, W. Germination of an idea: priming of seeds. University of Nottinghan School of Agriculture Report, England, $1973 / 74$, p. 50-67.

HEYDECKER, W. \& COOLBEAR, P. Seed treatments for improved performance - survey and attempted prognosis. Seed Science and Technology, Wageningen, 5(2): 353-425, 1977 .

HEYDECKER, W.; HIGGINS, J.\& GULLIVER, R. L. Accelerated 
germination by osmotic seed treatment. Nature, London, 246(5427): 42-44, 1973 .

HEYDECKER, W.; HIGGINS, J. e TURNER, $Y_{\text {. }} J_{\text {. Invigoration of }}$ seeds? Seed Science and Technology, Wageningen, 3(3/4): $881-8,1975$.

HUANG, G.; MCCRATE, A. J.; VARRIANO-MARSTON, E. \& PAULSEN, G. M. Caryopsis structural and imbibitional characteristics of some hard red and white wheats. Cereal Chemistry, St. Paul, 60(2): 161-5, 1983.

HWANG, D. L.; YANG, W. K. \& FOARD, D. E. Rapids release of protease inhibitors from soybeans. Immunochemical quantitation and parallels with lectins. Plant Physiology, Rockville, 61(1): 30-4, 1978.

IBRAHIN, A. E. \& ROBERTS, E.H. Viability of seeds. Journal of Experimental Botany, Oxford, 34(141): 620-30, 1983.

IDRIS, M. \& ASLAM, M. The effect of soaking and drying seeds before planting on germination and growth of Triticum vulgare under normal and saline conditions. Canadian Journal of Botany, Ottawa, 53(10): 1328-32, 1975. 
KALAKANNAVAR, R. M。; SHASHIDHARA, S. A.; KULKARNI, G. N. Effect of grading on quality of wheat seeds. Seed Research, New Delhi, 17(2): 182-5, 1989.

KEEN, N. T. The isolation of phytoalexins from germinating seeds of Cicer arientinum, Vigna sinensis, Arachis hypogaea, and other plants. Phytopathology, St. Paul, 65(1): $91-2,1975$.

KERMODE, A.R.; BEWLEY, J.D.; DASGUPTA, J. \& MISRA, S . The transition from seed development to germination: a key role for desiccation? Hortscience, Alexandria, $21(5): 1113-17,1986$.

KHAN, A. A. \& KNYPL, J.S. Increase germination of seeds under stress by growth regulator infusion, osmotic preconditioning and a combination of two methods. Plant Physiology, Rockville, 59, 1977. (Suppl. Abstract 184)

KING, R. W. Abscisic acid in developing wheat grains and its relationship to grain growth and maturation Planta, Praga, 132(1): 43-51, 1976 .

KING, R. W. Water uptake in relation to pre-harvest sprouting damage in wheat: Grain characteristics. Australian Journal of Agricultural Research, East Melbourne, 35(3): 337-45, 1984. 
KIRSI, M. Proteinase inhibitors in germinating barley embrios. Physiologia Plantarum, Copenhagen, 32(1): $89-93,1974$.

KNITTLE, K. H. \& BURRIS, J.S. Effect of kernel maturation on subsequent seediig vigor in maize. Crop science, Madison 16(6): 851-55, 1976.

KNYPL, J.S. \& KHAN, A.A. Osmoconditioning of soybean seeds to improve performance at suboptimmal temperatures. Agronomy Journa 1, Madison, 73(1): 112-6, 1981.

KNYPL, J.S.; JANAS, K. M. \& RADZIWONOWSKA-JOZWIAK, A. IS enhanced vigour in soybean (Glicine max) dependente on activation of protein turnover during controlled hydratiom of seeds? Physiologie Vegétale, Paris, 18(1): $157-61,1980$.

KOOSTRA, F. Changes in seed ultrastructure during senescence. Seed Science and Technology, Wageningen, $1(2): 417-25,1973$.

KRAFT, J.M. The role of delphinidin and sugars in the resistance of pea seedlings of Fusarium root rot. Phytopathology, St.Pau1, 67(8): 1057-61, 1977. 
LABOURIAU, L. G. A germinação das sementes. Washington, OEA, 1983. 174p. (OEA. Coleção de monografias científicas - Biológicas no 24 ).

LIENER, I. E. Phytohemagglutinins (Phytolectins). Annual Review of Plant Physiology, Palo Alto, 27: 291-319, 1976.

LUSH, W. M. \& GROVES, R. H. Germination, Emergergence and establishment of wheat and ryegrass in response to natural and artificial hydratation-dehydratation cicles. Australian Journal Agricultural Research, East Melbourne 32(5): 731-9, 1981 .

LUSH, W. M.; GROVES, R. H. \& KAYE, P. E. Presowing hydratation-dehydratation treatments in relation to seed germination and early seedling growth of wheat and rye grass. Australian Journal of Plant Physiology, East Melbourne 8(4/5): 409-25, 1981 .

MAGUIRE, J.A. Speed of germination: aid in selection an evaluation for seedling emergence and vigor. crop Science, Madison, 2(2): 176-7, 1962.

MAGUIRE, J. D. Physiological disorders in germinating seeds induced by the environment. In: HEYDECKER, W., 
ed., Seed Ecology, London, Butterworths, 1973. 578 p.

MANDAL, A. K. \& BASU, R. N. Effect of water-soaked and dried seeds on yield of wheat with or without fertilizer application. Indian Journal of Agricultural Science, New Delhi, 57(7): 517-9, 1987a.

MANDAL, A.K. \& BASU, R. N. Midterm and presowing hydratation-dehydratation treatmentes for improved field performance of wheat. Field Crops Research, Amsterdan, 15(3/4): 259-65, 1987b.

MARCOS FILHO, J. Germinação de sementes. In: Semana de atualização em produção de sementes, 1. Piracicaba, 1986. Campinas, Fundação Cargi11, 1986. p. 11-39.

MARCOS FILHO, J.; CICERO, S. M.; SILVA, W. R. AValiação da qualidade das sementes. Piracicaba, FEALQ, 1987. 230p.

MARCUS, A.; FELLEY, J.\& VOLCANI, T. Protein syntes is in inbibed seeds. III. Kinetics of amino acid incorporation, ribosome activation, and polysome formation. Plant Physiology, Kutztown, 41(7): 1167-72, 1966.

MATTHEUS, S. \& POWELL, A. A. Environmental and 
physiological constraints on field performance of seeds. Hortscience, Alexandria, 21(5): 1125-8, 1986.

MAY, L. H.; MILTHORPE, E.'J. \& MILTHORPE, F. L. Pre-sowing hardening of plants to drought - an appraisal of the contributions by P. A. Genkel. Field Crop Abstracts, Commonwealth Agricultural Bureaux - England, may 15(2): $93-8,1962$.

MAYER, A. M. \& POLJAKOFF-MAYBER, A. The Germination of Seeds. Pergamon Press, Oxford. 1975. 236p.

McCRAIG, T.N. \& DePAUW, R. M. Breeding for preharvest sprouting in white-seed-coat spring wheat. Crop Science, Madison, 32(1): 19-23, 1992.

McGEE, D. C. Symposium on deterioration mechamisms in seeds. Phytopathology, St. Paul, 73(2): 314-5, 1983.

MCKERSIE, B. D. \& TOMES, D. T. Effect of dehydration treatments on germination, seedling vigour, and cytoplasmic leakage in wild oats and birdsfoot trefoil. Canadian Journal of Botany, Ottawa, 58(4): 471-6, 1980.

MEHTA, Y. R. Doenças do Trigo e seu controle. São Paulo, Editora Agronômica Ceres, 1978. 190 p. 
MEHTA, Y.R.; IGARASHI, S.; NAZARENO, N.R.X. Doenças do Trigo no Estado do Paraná: guia para identificação e controle. 2 ed.Londrina, IAPAR, 1987. 54 p.

MENTEN, J. O. M. I Semana de atualizacão em patologia de sementes, 25 a 28 julho de 1988. Piracicaba, FEALQ, 1988. $76 \mathrm{p}$.

MERYMAN, H.T. Freezing injury and its prevention in living cells. Annual Review of Biophysics and Bioengineering, New York, 3: 341-63, 1974 .

MEURS, C.; BASRA, A. S.; KARSEN, C. M. \& LOON, L. C. van. Role of abscisic acid in the induction of desiccation tolerance in developing seeds of Arabidopsis thaliana. Plant Physiology, Rockville, 98(4): 1484-93, 1991.

MILTHORPE, F. L. Changes in drought resistance of wheat seedlings during germination. Annals of Botany, London, $14(9): 79-89,1950$.

MIRELMAN, D.; GALUN, E.; SHARON, N. \& LOTAN, R. Inhibition of fungal growth by wheat germ agglutinin. Nature, London, 256(3): 414-16, 1975.

MITCHELL, B.; ARMSTRONG, M.; BLACK, M. \& CHAPMAN, J. 
Physiological aspects of sprouting and spoilage in developing Triticum aestivum L. (wheat) grains. In: P. D. HEBblethWAITE, ed., seed production, London, Butterworth, 1978. p.339-56

MOHAMMAD, S.; SUNDER, R. S. Effect of seed treatment and storage containers on the maintenance of viability of sunflower seed. Tropical Science, London, 31(3): 223-8, 1991.

MOTTA, C. A. P. Comparação de testes de vigor em sementes de soja com a emergência das sementes a campo, Pelotas, 1986, 90p. (Mestrado - Universidade Federal de Pelotas)

NASSER, L. C. B. Testes de sanidade de sementes de trigo. In: SOAVE, J. \& WETZEL, M. M. V. S., ed., Patologia de sementes. Campinas, Fundação Cargill, 1987, p.469-80.

NATH, S.; COOLBEAR, P.; HAMPTON, J. G. Hydratationdehydratation treatments to protect or repair stored 'Karamu' wheat seeds. Crop Science, Madison, 31(3): $822-6,1991$.

NAWA, Y. \& ASAHI, T. Rapid development of mitochondria in pea cotyledons during the early stage of germination. Plant Physiology, Washington, 48(6): 671-4, 1971. 
NEERGARD, P. Seed Pathology, London, MacMillan, 1979, V.1. $838 \mathrm{p}$.

OSBORNE, D. J. Deoxyribonucleic acid integrity and repair in seed germination: the importance in viability and survival In: KHAN, A. A., ed, The Physiology and Biochemistry of seed Development, Dormancy and Germination. Amsterdan, Elsevier Biomedical Press, 1982. p.435-63.

PETERSON, C. M.; KLEPPER, B.; RICKMAN, R.W. Seeds reserves and seedling development in winter wheat. Agronomy Journa 1, Madison, 81(2): 245-51, 1989.

PFLEgER, F.L. \& HARMAN, G.E. Inability of storage fungi to invade pea embrios: Evidence against phytoalexin involvement. Phytopathology, St.Paul, 65(5): 642-3, $1975 a$.

PFLEGER, F.L. \& HARMAN, G.E. Fungal ant isporulant activity of a complex lipid fraction extrated from pea seeds. Canadian Journal of Botany, Ottawa, 53(12): 1625-9, $1975 b$.

PHANEENDRANATH, B. R. Influence of amount of water in paper towel on stand germination tests. Journal of seed Technology, East Lansing, 5(2): 82-7, 1980. 
PRIESTLEY, D. A. \& LEOPOLD, A. C. Lipid changes during natural ageing of soybeans seeds. Physiologia Plantarum, Copenhagen, 59(3): 467-70, 1983.

PRISCO, J.T. \& O’LEARY, J.W. Osmótic and "tóxic" effects of salinity on germination of Phaseolus vulgaris L. seeds. Turrialba, San José, 20(2): 177-84, 1970 .

PULL, S. P.; PUPKE, S. G.; HYMOWITZ, T. \& ORF, J.H. Soybean lines lacking the 120,000-dalton seed lectin. Science, New York, 200(10): 1277-9, 1978.

REIS, E. M. Patologia de Sementes de Cereais de Inverno. São Paulo, CNDA, 1987, 32 p.

RERKASEM, K.; STERN, W. R. \& GOODCHILD, N.R. Associated growth of wheat and annual ryegrass. II. Effect of varying the time of ryegrass germination in stands of wheat. Australian Journal of Agricultural Research, East Melbourne. 31(4): 659-72, 1980 .

ROBERTS, E. H. Dormancy: a factor affecting seed survival in the soil. In: ROBERTS, E. H., ed., viability of Seeds, London, Chapman \& Hall, 1972a, 448 p.

ROBERTS, E.H. Citological, genetical and metabolic changes 
associated with loss of viability. In: ROBERTS, E. H., ed., Viability of Seeds, London, Chapman \& Hall, 1972b. $448 \mathrm{p}$.

ROBERTS, E. H. Predicting the storage life of seeds. Seed Science and Technology, Wageningen, 1(2): 499-514, 1973.

ROBERTS, E. H. Physiology of ageing and its aplication to drying and storage. Seed Science and Technology, Zürich, 9(2): 359-72, 1981 。

ROGAN, P. G. \& SIMON, E. W. Root growth and onset of mitosis in germinating Vicia faba. New Phytologist, London 74(2): 273-5, 1975 .

ROGERSON, N.E. \& MATTHEWS, S. Respiratory and carbohydrate changes in developing pea (Pisum sativum L.) seeds in relation to their ability to withstand desiccation. Journal of Experimental Botany, Oxford, 28(103): $304-13,1977$.

RYAN, C. A. Proteolytic enzymes and their inhibitors in plants. Annual Review of Plant Physiology, Palo Alto, 24: $173-96,1973$. 
SACHS, M. Priming of watermelon seeds for low-temperature germination. Journal of American Society for Horticulturae Science, St. Joseph, 102(2): 175-78, 1977 .

SALIM, M. H. \& TODD, G.W. Seed soaking as a pre-sowing hardening treatment in wheat and barley seedlings. Agronomy Journal, Madison, 60(2): 179-82. 1968.

SALTER, P.J. \& DARBY, R. J. Syncronization of germination of celery seeds. Annals of Applied Biology, London, $84(3): 415-24,1976$.

SEN, S. \& OSBORNE, D. J. Germination of rye embryos following hydratation - dehydratation treatments: enhancement of protein and RNA syntesis and earlier induction of DNA replication. Journal of Experimental Botany, Oxford, 25(89): 1010-19, 1974.

SHANDS, H. L.; JANISH, D.C.\& DICKSON, A.D. Germination response of barley following diferent harvesting conditions. Crop Science, Madison, 7(5): 444-6, 1976.

SHORT, G. E。 \& LACY, M. L. Carbohydrate exudation from pea seeds: Effect of cultivar, seed age, seed color, and temperature.Phytopathology, St. Paul, 66(2): 182-7, 1976 . 
SILVA, W. R. da Relações entre a disponibilidade de água, tratamento fungicida e germináção de sementes de milho (Zea mays L.). Piracicaba, 1989. 113p. (Doutorado Escola Superior de Agricultura "Luiz de Queiroz" /USP).

SIMMONS, S. R. Growth, Development and Physiology. in: HEYNE, E.G., ed., wheat and wheat improvement. Madison, American Society of Agronomy, 1987. p.115-50

SIMON, E.W. Phospholipids and plant membrane permeability. New Phytologists, London, 73(3): 377-420, 1974.

SIMON, E. W. Early events in germination, In: MURRAY, D. R., ed., Seed Physiology. London, Academic Press, 1984. v. 2, p.77-115.

SIMON, E. W. \& MILLS, L. R. Imbibition, leakage and membranes, In: NOZZOLILO, C.; LEA, P.J. \& LOEWUS, F.A., ed., Mobilization of reserves in germination, Recent advances in phytochemistry. New York, Plenum Press, 1983. v. 17, p.9-27

SIMON, E. W. \& RAJA-HARUM, R.M. Leakage during imbibition. Journal of Experimental Botany, Oxford, 23(77): $1076-85,1972$. 
SUTCLIFFE, I.M. \& BRYANT, J.A. Biochemistry of germination and seedling growth in: SUTCLIFFE, J.F. \& PATE, J.S., ed., The Physiology of the Garden Pea. London, Academic Press, 1977. p.45-82.

TEKRONY, D. M.; EGLI, D. B.; BALLES, J.; PFEIFFER, T. \& FELLows, R. J. Physiological maturity in soybean. Agronomy Journa 1, Madison, 71(5): 771-75, 1979.

THOMAS, $H_{0}$ Control mechanisms in the resting seed. In: ROBERTS, E.H., ed., Viability of Seeds. London, Chapman \& Hall, 1972, p. 360-96.

TILDEN, R. L. \& WEST, S.H. Reversal of effects of aging in soybean seeds. Plant Physiology, Rockville, 77(3): $584-86,1985$.

TOLEDO, F. F \& MARCOS FILHO, J. Manual das sementes: tecnologia da produção. São Paulo, Editora Agronômica Ceres, 1977. 224p.

TONKIN, J.H.S., Pelleting and other presowing treatments. Adv. Res, Techn. Sem., Wageningem, 4: 84-105, 1979.

TONKIN, J.H.S. Pelleting and other pre-sowing treatments Adv. Res. Techn. Sem., Wageningen, 9: 94-127, 1985. 
VICENT, E. M. \& CAVERS, P. B. The effects of wetting and drying on subsequent germination of Rumex crispus. Canadian Journa 7 of Botany, Ottawa, 56(18): 2207-17, 1978 .

VILLIERS, T. A. Ageing and longevity of seeds in field conditions. in: HEYDECKER, W., ed., seed Ecology. London, Butterworths, 578 pp. 1973.

VILLIERS. T. A. Seed ageing, chromosome stability and extended viability of seeds stored fully imbibed. Plant Physiology, Rockville, 53(6): 875-8, 1974.

VILLIERS, T.A. \& EDGCUMBE, D. J. On the cause of seed deterioration in dry storage. Seed science and Technology, Wageningen, 3(3/4): 761-74, 1975.

WALLACE, H.A. H., Factors affeting subsequent germination of cereal seed sown in soils of subgermination moisture content Canadian Journal ò Botany, Ottawa, 38(2): 287-306, 1960。

WARD, F.H. \& POWELL, A.A. EVidence for repair processes in onion seeds during storage at high seed moisture contents. Journal of Experimental Botany, Oxford, $34(139): 277-82,1983$. 
WATT, L. A. The effect of water potencial on the germination behaviour of several warm season grass species with special reference to cracking black clay soil. Journal of Soil Conservation, Melbourne, 30(2): 28-41, 1974 .

WATT, L. A. Some characteristics of germination of Queensland blue grass on the cracking black earths. Australian Journal of Agricultural Research, East Melbourne, 29(6): 1147-55, 1978 .

WATT, L. A. Germination characteristics of several grass species as affected by limiting water potencials imposed through a Cracking Black Clay Soil. Australian Journal of Agricultural Research, East Melbourne, 33(2): 387-402, 1982 .

WEBSTER, B. D. \& LEOPOLD, A. C. The ultraestruture of dry and imbibed cotyledons of soybean. American Journal of Botany, Columbus, 64(10): 1286-93, october 1977 .

WILSON, A. M. Amylase syntesis and stability in crested wheatgrass seeds at low water potencials. Plant Physiology, Washington, 48(5): 541- 6, 1971.

WILSON JR., D. O. \& MCDONALD JR., M. B. The lipid 
peroxidation model of seed ageing. Seed Science and Technology, Wageningen, 14(2): 269-300, 1986.

WOODSTOCK, L. W.; SIMKIN, J.\& SCHROEDER, E. Freeze-drying to improve seed storability. Seed science and Technology, Wageningen, 4(2): 301-11, 1976.

ZONTA, E. P.; MACHADO, A. D. \& SILVEIRA JUNIOR, P. Sistema de Análise Estatística para Microcomputadores - SANEST, Pelotas, 1984 . 